\title{
Essays on excise taxation: Cross -border effects, quality substitution, and tax earmarking
}

Todd M. Nesbit

West Virginia University

Follow this and additional works at: https://researchrepository.wvu.edu/etd

\section{Recommended Citation}

Nesbit, Todd M., "Essays on excise taxation: Cross -border effects, quality substitution, and tax earmarking" (2005). Graduate Theses, Dissertations, and Problem Reports. 2317.

https://researchrepository.wvu.edu/etd/2317

This Dissertation is protected by copyright and/or related rights. It has been brought to you by the The Research Repository @ WVU with permission from the rights-holder(s). You are free to use this Dissertation in any way that is permitted by the copyright and related rights legislation that applies to your use. For other uses you must obtain permission from the rights-holder(s) directly, unless additional rights are indicated by a Creative Commons license in the record and/ or on the work itself. This Dissertation has been accepted for inclusion in WVU Graduate Theses, Dissertations, and Problem Reports collection by an authorized administrator of The Research Repository @ WVU.

For more information, please contact researchrepository@mail.wvu.edu. 


\title{
ESSAYS ON EXCISE TAXATION: \\ CROSS-BORDER EFFECTS, QUALITY SUBSTITUTION, AND TAX EARMARKING
}

\author{
Todd M. Nesbit \\ Dissertation Submitted to the \\ College of Business and Economics at \\ West Virginia University \\ in partial fulfillment of the requirements for the degree of \\ Doctor of Philosophy \\ In \\ Economics
}
Russell S. Sobel, Ph.D., Chair Stratford M. Douglas, Ph.D. Robert A. Lawson, Ph.D. Santiago M. Pinto, Ph.D. Mehmet S. Tosun, Ph.D.

Department of Economics
Morgantown, West Virginia 2005

\footnotetext{
Keywords: excise tax, cross-border sales, quality substitution, earmarking, intergovernmental grants
} 


\section{ABSTRACT \\ ESSAYS ON EXCISE TAXATION: \\ CROSS-BORDER EFFECTS, QUALITY SUBSTITUTION, AND TAX EARMARKING}

\section{TODD M. NESBIT}

This dissertation is a collection of essays examining the secondary effects of excise taxation. The first chapter discusses the history of the excise tax in the United States and provides an introduction to some of the major areas of research examining the excise tax. In addition, this chapter outlines the research agenda for the dissertation. Chapter 2 considers the effects of cross-border sales and tourism on state tax revenues from wine and liquor taxation in the state of West Virginia. The empirical results of this chapter suggest that the revenue impact of cross-border shopping and tourism is economically significant relative to the total tax revenue collected from these sources. Chapter 3 empirically analyzes the effects of the gasoline excise tax on the purchase of gasoline grade. The results show that the per-unit excise tax causes consumers to substitute toward higher quality (higher octane) gasoline while the ad valorem excise tax exerts little influence on the purchase of gasoline grade. Chapter 4 builds upon the previous chapter by modifying the empirical model to control for spatial dependence and controlling for the impact that cross-border shopping may have on the purchase of quality. The results suggest that an increase in a state's per-unit excise tax induces two conflicting effects on the purchase of product quality, with the cross-border effect dominating the relative-price effect. Thus, an increase in a state's per-unit excise tax is found to cause a decline in average product quality in the state. Chapter 5 examines the potential for crowd-out in state highway financing. The results indicate that states respond to federal grants and state earmarked revenues similarly and that these sources of revenue do not cause crowding-out. Finally, Chapter 6 summarizes the major findings of the previous chapters and discusses areas of future research. 


\section{ACKNOWLEDGEMENTS}

I would like to thank my dissertation chair, Russell S. Sobel, for providing me with the encouragement and guidance needed for me to complete my graduate coursework and this dissertation. I am also grateful for Robert A. Lawson, for without him I likely would have never pursued a bachelor's degree in economics, let alone a doctorate degree. Both Russ and Bob were always willing to go beyond what was asked of them as advisors and mentors, and for that I am thankful. I am very fortunate to have had the opportunity to work with each of them.

I would also like to thank the remaining members of my dissertation committee, Stratford M. Douglas, Santiago M. Pinto, and Mehmet S. Tosun for all their help both in the classroom and during the process of writing this dissertation. 


\section{TABLE OF CONTENTS}

Chapter 1:

Introduction: The Excise Tax and Research Agenda

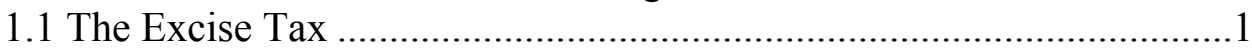

1.2 Dissertation Research Agenda ..................................................6

Chapter 2:

The Revenue Impacts of Cross-Border Sales and Tourism:

Wine and Liquor Taxation

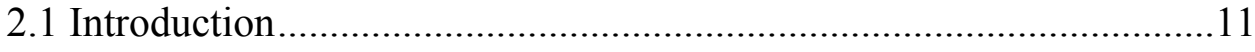

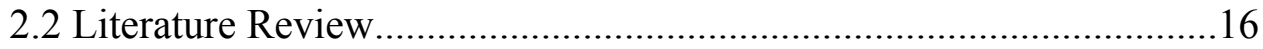

2.3 Exporting Taxes Through Wine and Liquor Sales ..........................21

2.4 Methodology, Data, and Empirical Evidence ..................................27

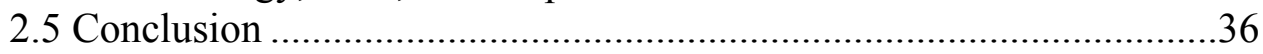

Chapter 3:

Excise Taxation and Product Quality: The Gasoline Market

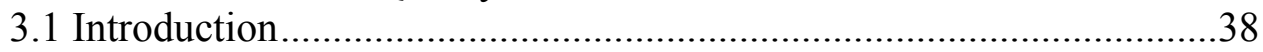

3.2 A Review of the Empirical Literature................................................39

3.3 Empirical Test of the Market for Gasoline ........................................47

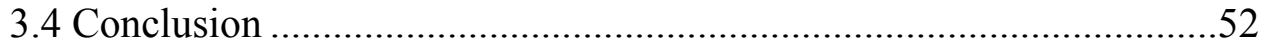

Chapter 4:

Cross-Border Shopping and Product Quality: The Gasoline Market

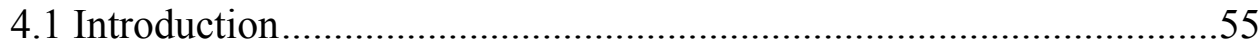

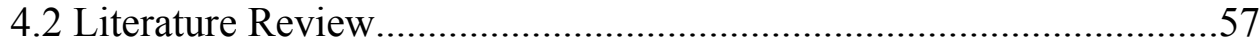

4.3 Empirical Model and Results ....................................................62

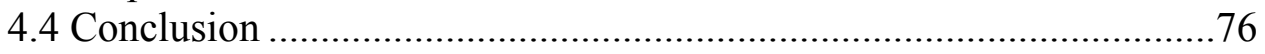

Chapter 5:

Federal Grants, Earmarked Revenues, and Budget Crowd-Out:

State Highway Funding

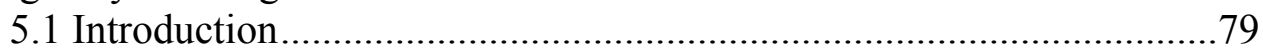

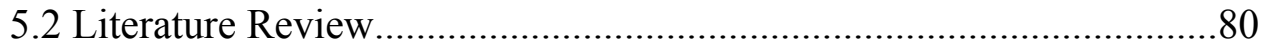

5.3 The State Highway Funding Process ….......................................... 90

5.4 Empirical Data and Results........................................................ 92

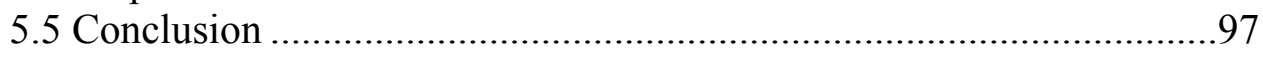

Chapter 6:

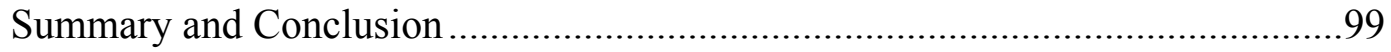

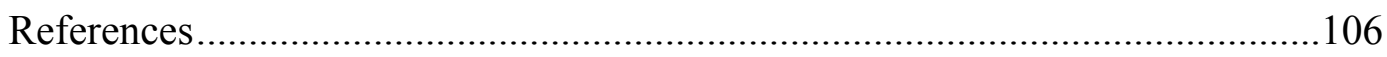




\section{LIST OF TABLES}

Table 1.1 Federal Excise Tax Collections, 1940-2004e......................................

Table 2.1 Sales and Alcohol Excise Tax Rates, 2004 ....................................14

Table 2.2 Effective Tax Rates for Wine and Liquor ......................................22

Table 2.3 Ordinary Least Squares Results ...................................................29

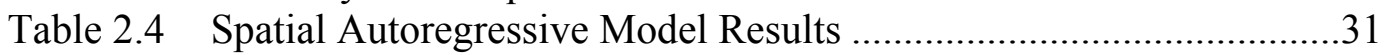

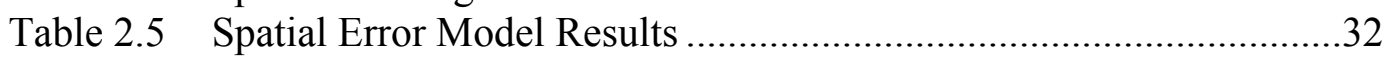

Table 2.6 Estimated Economic Impacts of Liquor Taxation..............................35

Table 3.1 Summary of Previous Empirical Results..........................................42

Table 3.2 Descriptive Statistics, 1991-2001 ..................................................48

Table 3.3 State-Fixed Effects Models .........................................................51

Table 4.1 State Tax Rates Applicable to Gasoline Sales..................................58

Table 4.2 Descriptive Statistics, 1994-2001 .....................................................64

Table 4.3 Ordinary Least Squares Model (OLS) .............................................68

Table 4.4 Spatial Lag Model (SAR) ............................................................... 71

Table 4.5 Spatial Error Lag Model (SEM) ....................................................72

Table 5.1 Some Estimates of the Flypaper Effect ........................................82

Table 5.2 Variable Definitions, Descriptive Statistics, and Sources ..................94

Table 5.3 State Highway Expenditures .........................................................96 


\section{Chapter 1 Introduction: The Excise Tax and Research Agenda}

excise: a hateful tax levied upon commodities, and adjudged not by common judges of property, but by wretches hired by those to whom the excise is paid.

\section{- Dictionary of the English Language, Samuel Johnson}

\subsection{The Excise Tax}

Paying taxes is commonly accepted as a necessary sacrifice for meeting government's revenue needs. The first taxes in the United States took the form of property taxes at the state level and tariffs (taxes on imported goods) at the national level. However, these taxes proved to be insufficient revenue sources to pay back the huge debt acquired from the Revolutionary War. In an effort to raise additional revenue to pay back the debt, Alexander Hamilton proposed the first excise tax in United States history in 1792: the Whiskey Tax. Excise taxes had always been met with a great deal of resistance in England, and the whiskey excise would prove no different in the United States. Yelvington (1997) argues that the tax would not have passed through the House if it had not been for Hamilton's argument that whiskey is a luxury and a sin that poses a threat to society's well-being. Thus, excise taxation became synonymous with the $\sin$ tax and luxury tax from its very beginning.

The whiskey tax lead to the Whiskey Rebellion by Pennsylvania farmers. After failed attempts to convince the farmers to pay the tax, military was brought in and the rebellion was called off. The imposition of the whiskey tax and the defeat of the 
Whiskey Rebellion mark an important point in history. First, the government showed that it could enforce its tax policies. Equally as important, the government found a new source of revenue: the selective excise tax. Policy-makers also discovered that resistance to taxation could be minimized if the taxed commodities are convincingly portrayed as sinful and harmful to society. To this day, increases in taxes are justified on these grounds.

Excise taxation did not become a stable resource for government revenue until the time of the Civil War. From that point onward, each successive war brought about increased usage of the excise tax. The importance of excise taxation as a source of federal revenue continued to rise until the introduction of the income tax in 1913. Excise taxes contributed over half of all federal government revenues in 1934; however, today federal excises account for less than two percent of federal revenues (Yelvington 1997). Table 1.1 displays the federal excise tax revenues from $1940-2004$ e in nominal dollars. Most of the federal revenues from excise taxation relied heavily on alcohol, tobacco, and gasoline excises until the 1980s when additional commodity taxes were introduced.

As described above, moderate levels of excise taxation are subject to little resistance due to the roles as sin and luxury taxes. Excise taxes can also be justified on efficiency grounds, relying on the Ramsey Rule. ${ }^{1}$ The Ramsey Rule states that taxes should be set inversely proportional to price elasticity so as to distort consumer purchases as little as possible. Excise taxes, if set in accordance with the Ramsey rule, can be part of an efficient tax scheme. The Ramsey Rule suggests that excise taxes may be more

\footnotetext{
${ }^{1}$ See Diamond (1975), Sandmo (1975), and Slemrod (1990) for more on optimal taxation.
} 
Table 1.1

Federal Excise Tax Collections

Fiscal Years 1940-2004e (\$Millions)

\begin{tabular}{|c|c|c|c|c|c|c|c|c|c|}
\hline & 1940 & 1950 & 1960 & 1970 & 1980 & 1990 & 2000 & 2003 & $2004 \mathrm{e}$ \\
\hline Total Excise & 1,977 & 7,550 & 11,676 & 15,705 & 24,329 & 35,345 & 68,865 & 67,524 & 70,776 \\
\hline $\begin{array}{l}\text { Federal Funds: } \\
\text { Alcohol } \\
\text { Tobacco } \\
\text { Telephone } \\
\text { Ozone Depleting Chemicals/Products } \\
\text { Transportation Fuels } \\
\text { Other federal Funds }\end{array}$ & $\begin{array}{l}623 \\
606\end{array}$ & $\begin{array}{l}2,180 \\
1,326\end{array}$ & $\begin{array}{l}3,127 \\
1,927\end{array}$ & $\begin{array}{l}4,646 \\
2,093\end{array}$ & $\begin{array}{l}5,601 \\
2,443\end{array}$ & $\begin{array}{r}5,695 \\
4,081 \\
2,995 \\
360 \\
2,460\end{array}$ & $\begin{array}{r}8,140 \\
7,221 \\
5,670 \\
125 \\
819 \\
717\end{array}$ & $\begin{array}{r}7,893 \\
7,934 \\
5,788 \\
\\
920 \\
1,269\end{array}$ & $\begin{array}{r}7,993 \\
7,990 \\
6,319 \\
303 \\
1,542\end{array}$ \\
\hline $\begin{array}{l}\text { Total Federal Funds } \\
\text { Trust Funds: } \\
\text { Highway } \\
\text { Airport and Airway } \\
\text { Black Lung Disability } \\
\text { Inland Waterway } \\
\text { Hazardous Substance Superfund } \\
\text { Oil Spill Liability } \\
\text { Aquatic Resources } \\
\text { Leaking Underground Storage Tank } \\
\text { Vaccine Injury Compensation }\end{array}$ & 1,977 & 7,550 & 9,138 & 10,352 & $\begin{array}{r}6,620 \\
1,874 \\
272\end{array}$ & $\begin{array}{r}13,867 \\
3,700 \\
665 \\
63 \\
818 \\
143 \\
218 \\
122 \\
159\end{array}$ & $\begin{array}{r}34,972 \\
9,739 \\
518 \\
101 \\
2 \\
182 \\
342 \\
184 \\
133\end{array}$ & $\begin{array}{r} \\
33,726 \\
8,684 \\
506 \\
90 \\
\\
\\
392 \\
184 \\
138 \\
\end{array}$ & $\begin{array}{r}35,512 \\
9,751 \\
542 \\
94\end{array}$ \\
\hline Total Trust Funds & & & 2,539 & 5,354 & 8,766 & 19,755 & 46,173 & 43,720 & 46,629 \\
\hline
\end{tabular}

Reproduced From Tax Foundation. Original Source: Office of Management and Budget 
efficient if imposed at the state level, then, since elasticity of demand can vary by state. ${ }^{2}$ For example, if the demand for gasoline in Ohio is more elastic than it is in Pennsylvania, then the tax in Ohio should be less than in Pennsylvania. However, this logic fails to describe much of the interstate tax differentials observed in the United States. For instance, proponents of the Ramsey Rule would argue that the elasticity of demand for beer in Missouri must be substantially higher than in most other states because the beer excise is well below the national average. The more likely explanation is that the elasticity of demand is similar to that in other states and that the low tax rate is due to the influence of a politically powerful interest group, namely Budweiser. ${ }^{3}$

The Ramsey Rule is based on the substitution effects between goods. However, consumers can substitute on many margins, including quality. Many goods are marketed in various quality-grades. Honda Civics come in DX, LX, and EX models. There are two distinct quality levels of cigarettes: generic-brand and premium-brand. And, gasoline is available in three different octane levels at nearly every pump. In addition to substituting towards other means of transportation such as biking or walking, consumers can substitute across these quality-grades of gasoline. Per unit excise taxes are explained to cause substitution in quality whereas ad valorem excises do not. This issue is addressed further in Chapter 3 and revisited in Chapter 4 in light of cross-border shopping.

\footnotetext{
${ }^{2}$ The Ramsey Rule also suggests that tax rates should be lower in states where cross-border shopping is more common because the ability of consumers to cross-border shop increases their elasticity of demand. The effects of cross-border shopping are examined further in Chapters 2 and 4.

${ }^{3}$ The Ramsey Rule with multiple individuals can generate a scenario in which tax rates differ across regions even though elasticity may be identical by weighting the welfare of each individual or group of individuals differently in the social welfare function.
} 
Ignoring the effects of cross-border shopping and quality substitution for the moment, the Ramsey Rule suggests that properly imposed excise tax policies can improve social welfare relative to other tax policy prescriptions. However, the Ramsey Rule inherently makes an important, and likely incorrect, assumption about policymakers. It assumes that the goal of a policy-maker is to maximize social welfare. According to public choice theory, this assumption is flawed. Public choice economists view policy-makers and all other individuals similarly—-they are self-interested agents rather than benevolent dictators. Public choice models of the public sector typically assume either a revenue-maximizing (Leviathan) government or a vote-maximizing policy-maker. ${ }^{4}$ The discussion below motivates the imposition of excise taxation using the vote maximizing model.

The primary source of political support (votes) comes from organized specialinterest groups. Special-interest groups exercise their political clout to secure concentrated benefits, often in the form of subsidies or protection against competitors and at the expense of a less organized group. In order to minimize the opposition to the tax increase used to fund special-interest legislation, the cost is spread over the general taxpaying public. Even if the total cost to taxpayers is greater than the total benefit to special-interest, the policy may still go uncontested since taxpayers as a group are rationally ignorant and unorganized. Each particular taxpayer may not (and likely does not) favor an increase in taxes, but the cost of opposing the policy is often greater than each individual's tax burden.

\footnotetext{
${ }^{4}$ See Buchanan and Tullock (1962), Buchanan (1976), Brennan and Buchanan (1980), Holcombe (2001), and Ekelund and Tollison (2001) for more on the public choice model and its implications for taxation.
} 
Lee (1997) suggests that at some level of government expenditure taxpayer opposition to an increase in taxes balances out against the special-interest demands for more government spending. Any proposal to increase expenditure beyond that level will be defeated due to voter opposition. Earmarking sin taxes enable policy-makers to minimize such opposition. Voters will often support taxes on activities which are considered immoral or sinful simply to express their discontent with such activities (i.e., the whiskey tax of 1792). If the revenue from sin taxes is earmarked for some moral purpose, such as education or health care, voters may offer support for the tax hike. Thus, with the understanding that the tax helps deter an immoral act and helps promote a moral purpose, the general voting public does not resist the increase in taxes.

Yet, as Buchanan (1963) explains, earmarking a tax for a specific public expenditure may not increase expenditure on the earmarked project, contrary to voter expectations. In a general-fund financing setting, the implementation of an earmarked tax may simply crowd-out the general funds previously used for the earmarked project. This can free general funds for some other use. The newly freed-up general funds may now be used to meet the demands of special-interest, which may or may not be associated with the earmarked project. In such a case, the policy-maker is able to increase specialinterest expenditures with little voter opposition. Earmarked excise taxes and the potential for crowding-out will be explored in further detail in Chapter 5.

\subsection{Dissertation Research Agenda}

There are four research chapters included in this dissertation that will examine some of the secondary effects of excise tax policies. Specifically, Chapters 2, 3, and 4 explore 
some of the various ways consumers respond to excise taxes, while Chapter 5 looks at earmarked taxation and the public budgeting process.

In chapter 2, the cross-border effects of excise taxation on tax revenues are examined by looking at wine and liquor sales in West Virginia. Tax rates on alcohol can differ by large amounts across state lines. For residents living close to a border where the tax on a commodity is significantly lower across the border, the consumer could potentially benefit from shopping across the border. If a large number of citizens choose to shop across the border, then the home state will lose a large sum of potential tax revenue. On the other hand, the state with the lower tax rate observes a significant increase in tax revenue, which can then be spent to benefit the constituents of that district. In other words, the policy-maker is able to export some of the tax burden to those who live outside the district. Attracting tourists, who will pay state taxes on their purchases, is another way states can export taxes. Tax exporting is beneficial to a policy-maker because he is able to gain additional voter support by providing more public services while not imposing additional costs on his constituents. The chapter's results show that the revenue impact of cross-border and tourism sales of wine and liquor in West Virginia is significant relative to total revenue from taxes on these commodities.

Chapter 3 considers the impact of excise taxation on consumers' choice of product quality. Alchian and Allen (1967) and Barzel (1976) theorized that the presence of a fixed unit charge, such as a per-unit excise tax, will cause consumers to substitute toward a higher quality version of the good. Barzel explains this occurrence by noting that the per-unit tax only taxes the quantity of a good that is consumed, leaving the quality attributes untaxed. Thus, consumers substitute away from the taxed attribute 
(which is quantity) and toward the untaxed attribute (which is quality). The specific ad valorem tax, on the other hand, taxes all attributes of the good and does not cause any quality substitution.

Nearly all empirical studies of this theory have used cigarette market data. Indeed, Barzel's original article, which examines the cigarette, gasoline, and alcohol markets, is the only one to test the theory in a market other than cigarettes, although he was able to find empirical support only in the cigarette market. Given that the empirical support for Barzel's theory has been limited to cigarettes, it is reasonable to question whether the theory is general to all cases of per-unit taxation or whether the theory is unique to cigarettes. The chapter addresses this question by testing the theory in the market for gasoline, a market in which Barzel was unable to find supporting evidence. The results show that in states with higher unit taxes on gasoline, the market share of premium-grade and mid-grade gasoline are higher, supporting Barzel's theory.

The analysis of chapter 4 combines the ideas of the previous two chapters, examining the effect of cross-border shopping on product quality. Interstate tax differentials are explained to cause many consumers to cross-border shop. Cross-border shoppers, relative to in-state shoppers, incur a larger fixed travel cost per trip because they travel further distances. According to the Alchian and Allen theorem, the presence of a fixed unit cost should increase average product quality. A state with a lower unit tax relative to its bordering states should observe greater product quality due to cross-border shopping. However, the analysis of Chapter 3 suggests that larger per-unit taxes leads to greater product quality because it reduces the relative price of higher quality. Thus, there 
are two conflicting effects of a change in a state's unit tax: the relative-price effect and the cross-border effect.

Chapter 4 attempts to measure these two conflicting effects on product quality in the market for gasoline. Tax rates on gasoline vary widely across states, causing some consumers to purchase gasoline across the state line at the expense of additional travel costs. The home-state tax rate is included to capture the relative-price effect. The average interstate tax differential is calculated for each state and is included to measure the cross-border impact on gasoline quality. The results from the model, corrected for spatial autocorrelation, suggest that the cross-border effect dominates the relative-price effect.

Chapter 5 of this dissertation examines the potential for crowd-out in state highway financing. State highway revenues from earmarked excise taxes on motor fuel, motor vehicles, and tolls account for about forty-eight percent of revenues used for state highway construction and maintenance. In addition, federal highway aid accounts for nearly twenty-seven percent. Previous literature on intergovernmental grants indicates a flypaper effect, in which states are observed to increase spending more from a federal grant than if the grant were given to residents in the form of tax relief. Theory suggests that state expenditures should respond identically in both situations. Thus, federal grant receipts are hypothesized to crowd-out state own-source funding. Earmarked tax revenues are predicted to result in a similar fashion, crowding-out general funds. Using state-level annual data from 1994-2002, the degree of crowding-out from earmarking and federal grant receipts in state highway funding is estimated. The results show that states 
respond to federal grants and earmarked revenues similarly and that these sources of revenue do not cause crowding-out. 


\section{Chapter 2 \\ The Revenue Impacts of Cross-Border Sales and Tourism: Wine and Liquor Taxation}

\subsection{Introduction}

Demand for state and local public services has grown tremendously in recent decades. But while voter demand for public services has grown, their dislike of taxes has not diminished. Indeed, voters appear as responsive as ever to increased taxation. This places policy-makers in a difficult situation: voters want more public services but they are unwilling to pay the full price for them. In the private market many of these services would remain unprovided because the willingness to pay is not large enough to cover the costs of provision. In the public sector, however, political pressures encourage the provision of many inefficient goods and services. Politicians unable to both increase the provision of public services and hold the tax rates in the home district steady may be replaced in an upcoming election.

If a politician is to remain in office, then, he must increase the provision of public goods and services within the home jurisdiction without subjecting his constituents to excessive taxation. In other words, the politician must find ways to export the burden of the increased provision of public goods to residents outside of the home district. The burden can be shifted outside of the jurisdiction in two ways, both of which are commonly employed. The first involves the federal provision of the local public good or service. The first formal model of this idea was presented in Weingast, Shepsle, and Johnson (1981). State representatives in the federal legislature bargain with one-another (through vote-trading or pork-barrel legislation) in an attempt to secure localized benefits from federal expenditures. The result of such practices is that the federal government 
increases taxes by a small amount on all constituents in all districts, raising a large pool of revenue that can be used to provide public goods or services in a particular district. A major implication of the theory presented in their paper is that the size of the federal government increases with the number of districts, commonly referred to as the "Law of $1 / \mathrm{N}^{\prime \prime}$ in the literature. ${ }^{5}$

The second method of providing local public goods and services, and the topic of this chapter, is to export the tax burden to constituents of other neighboring districts. Tax exporting occurs when residents of one state travel into another state where they make purchases, contributing to that state's tax revenues. Since these revenues are used to provide public services for residents of that state, the visitor will not receive the direct benefits from the tax payments (unless spillovers are present). Cross-border sales and tourism offer a potential for tax exporting. Tax revenues from tourist activities depend on the attractions present in the state, such as national or state parks, resorts, and college and professional sporting events. State revenues from cross-border sales, on the other hand, depend on the relative prices across state lines, locational convenience of shopping centers near state borders, and travel costs.

When prices across neighboring political jurisdictions differ by large amounts, many consumers will make purchases across the border to take advantage of the welfare gains arising from the lower prices in near-by, lower-cost regions. A primary, although not exhaustive, cause of interstate price differentials is the varying tax treatment of goods and services from one state to the next. Alcohol, cigarettes, and gasoline are the most prominent examples for which tax rates vary widely across states. Table 2.1 provides a

\footnotetext{
${ }^{5}$ Brennan and Buchanan (1980) reach the opposite conclusion, arguing that a greater number of districts can reduce the size of government.
} 
comparison of state sales tax rates and excise tax amounts applied to beer, wine, and liquor sales as of January 1, 2004.

As is evident in Table 2.1, tax treatment varies substantially from state to state for each of the three alcoholic beverages. Considering the lower forty-eight states only, per unit excise taxes range from $\$ 0.02 /$ gallon (WY) to $\$ 0.77 /$ gallon (SC) on beer; from $\$ 0.11$ gallon (LA) to $\$ 2.25 /$ gallon (FL) on wine; and from $\$ 1.50$ /gallon (MD) to $\$ 6.50$ /gallon (FL) on liquor. In addition to excise taxes, many states apply the state sales tax to the purchase of alcoholic beverages. Sales tax rates, as can be seen in column two of Table 2.1, range from zero percent (DE) to seven percent (MS, RI, and TN). To further complicate matters, some states, commonly referred to as "control states," permit wine and liquor sales only through state-owned or state-licensed stores. The sale of wine and liquor in control states is subject to state ad valorem mark-ups at wholesale, retail, or both. These mark-ups are essentially hidden taxes. This variation in tax treatment of alcohol sales across states can lead to substantial interstate price differentials. These price differentials combined with the portability of alcoholic beverages suggests that cross-border sales may serve as an important determinant of state-level alcohol sales and tax revenue from those sales.

This chapter measures the revenue impacts of cross-border sales and tourism in the market for wine and liquor using county-level data from the state of West Virginia. Wine and liquor sales make for interesting studies of cross-border sales because of its portability and because of the sizable variation in tax treatment as discussed above. West Virginia provides a unique and interesting testing ground for cross-border sales because of its unique geography. Twenty-eight of West Virginia's fifty-five counties border at 
Table 2.1

Sales and Selected Excise Tax Rates

January, 1, 2004

\begin{tabular}{|c|c|c|c|c|c|c|c|}
\hline & State Sales & Beer $\mathrm{E}$ & se Tax & Wine $\mathrm{E}$ & ise Tax & Liquor & ise Tax \\
\hline & (\%) & (\$/gallon) & Sales Tax & (\$/gallon) & Sales Tax & (\$/gallon) & Sales Tax \\
\hline Alabama & 4.00 & 0.53 & Yes & 1.70 & Yes & [2] & Yes \\
\hline Alaska & 0.00 & 1.07 & n.a. & 2.50 & n.a. & 12.80 & n.a. \\
\hline Arizona & 5.60 & 0.16 & Yes & 0.84 & Yes & 3.00 & Yes \\
\hline Arkansas & 5.13 & 0.23 & Yes & 0.75 & Yes & 2.50 & Yes \\
\hline California & 6.00 & 0.20 & Yes & 0.20 & Yes & 3.30 & Yes \\
\hline Colorado & 2.90 & 0.08 & Yes & 0.32 & Yes & 2.28 & Yes \\
\hline Connecticut & 6.00 & 0.19 & Yes & 0.60 & Yes & 4.50 & Yes \\
\hline Delaware & 0.00 & 0.16 & n.a. & 0.97 & n.a. & 3.75 & n.a. \\
\hline District of Columbia & 5.75 & 0.09 & Yes & 0.30 & Yes & 1.50 & Yes \\
\hline Florida & 6.00 & 0.48 & Yes & 2.25 & Yes & 6.50 & Yes \\
\hline Georgia & 4.00 & 0.48 & Yes & 1.51 & Yes & 3.79 & Yes \\
\hline Hawaii & 4.00 & 0.92 & Yes & 1.36 & Yes & 5.92 & Yes \\
\hline Idaho & 6.00 & 0.15 & Yes & 0.45 & Yes & [2] & Yes \\
\hline Illinois & 6.25 & 0.19 & Yes & 0.73 & Yes & 4.50 & Yes \\
\hline Indiana & 6.00 & 0.12 & Yes & 0.47 & Yes & 2.68 & Yes \\
\hline lowa & 5.00 & 0.19 & Yes & 1.75 & Yes & [2] & Yes \\
\hline Kansas & 5.30 & 0.18 & -- & 0.30 & No & 2.50 & No \\
\hline Kentucky & 6.00 & 0.08 & Yes & 0.50 & Yes & 1.92 & Yes \\
\hline Louisiana & 4.00 & 0.32 & Yes & 0.11 & Yes & 2.50 & Yes \\
\hline Maine & 5.00 & 0.35 & Yes & 0.60 & Yes & {$[2]$} & Yes \\
\hline Maryland & 5.00 & 0.09 & Yes & 0.40 & Yes & 1.50 & Yes \\
\hline Massachusettes & 5.00 & 0.11 & Yes & 0.55 & Yes & 4.05 & Yes \\
\hline Michigan & 6.00 & 0.20 & Yes & 0.51 & Yes & {$[2]$} & Yes \\
\hline Minnesota & 6.50 & 0.15 & -- & 0.30 & -- & 5.03 & -- \\
\hline Mississippi & 7.00 & 0.43 & Yes & 0.35 & Yes & {$[2]$} & Yes \\
\hline Missouri & 4.23 & 0.06 & Yes & 0.36 & Yes & 2.00 & Yes \\
\hline Montana & 0.00 & 0.14 & n.a. & 1.06 & n.a. & {$[2]$} & n.a. \\
\hline Nebraska & 5.50 & 0.31 & Yes & 0.95 & Yes & 3.75 & Yes \\
\hline Nevada & 6.50 & 0.16 & Yes & 0.70 & Yes & 3.60 & Yes \\
\hline New Hampshire & 0.00 & 0.30 & n.a. & {$[1]$} & n.a. & {$[2]$} & n.a. \\
\hline New Jersey & 6.00 & 0.12 & Yes & 0.70 & Yes & 4.40 & Yes \\
\hline New Mexico & 5.00 & 0.41 & Yes & 1.70 & Yes & 6.06 & Yes \\
\hline New York & 4.25 & 0.11 & Yes & 0.19 & Yes & 6.44 & Yes \\
\hline North Carolina & 4.50 & 0.53 & Yes & 0.79 & Yes & {$[2]$} & Yes \\
\hline North Dakota & 5.00 & 0.16 & -- & 0.50 & -- & 2.50 & -- \\
\hline Ohio & 6.00 & 0.18 & Yes & 0.32 & Yes & [2] & Yes \\
\hline Oklahoma & 4.50 & 0.40 & Yes & 0.72 & Yes & 5.56 & Yes \\
\hline Oregon & 0.00 & 0.08 & n.a. & 0.67 & n.a. & {$[2]$} & n.a. \\
\hline Pennsylvania & 6.00 & 0.08 & Yes & {$[1]$} & Yes & {$[2]$} & Yes \\
\hline Rhode Island & 7.00 & 0.10 & Yes & 0.60 & Yes & 3.75 & Yes \\
\hline South Carolina & 5.00 & 0.77 & Yes & 0.90 & Yes & 2.72 & Yes \\
\hline South Dakota & 4.00 & 0.27 & Yes & 0.93 & Yes & 3.93 & Yes \\
\hline Tennessee & 7.00 & 0.14 & Yes & 1.21 & Yes & 4.40 & Yes \\
\hline Texas & 6.25 & 0.19 & Yes & 0.20 & Yes & 2.40 & Yes \\
\hline Utah & 4.75 & 0.41 & Yes & {$[1]$} & Yes & [2] & Yes \\
\hline Vermont & 6.00 & 0.27 & no & 0.55 & Yes & [2] & No \\
\hline Virginia & 3.50 & 0.26 & Yes & 1.51 & Yes & [2] & Yes \\
\hline Washington & 6.50 & 0.26 & Yes & 0.87 & Yes & [2] & Yes \\
\hline West Virginia & 6.00 & 0.18 & Yes & 1.00 & Yes & {$[2]$} & Yes \\
\hline Wisconsin & 5.00 & 0.06 & Yes & 0.25 & Yes & 3.25 & Yes \\
\hline Wyoming & 4.00 & 0.02 & Yes & {$[1]$} & Yes & {$[2]$} & Yes \\
\hline US Median & & 0.19 & & $\frac{L-1}{0.64}$ & & 3.75 & \\
\hline
\end{tabular}

Source: Federation of Tax Administrators

[1] All wine sales are through state stores. Revenue in these states is generated from various taxes, fees, and net profits.

[2] In 18 states, the government directly controls the sales of distilled spirits. Revenue in these states is generated from

various taxes, fees, and net liquor profits. 
least one other state, and each state taxes wine and liquor differently. Additionally, since the mean income in the state is well below the national average, policy-makers face increased difficulty raising tax revenue from their constituents even though the demand for public assistance is quite large. Thus, given the demographics and geography of the state, tax exporting is an attractive solution for policy-makers in West Virginia.

Data for each of the fifty-five counties in West Virginia from 1993 - 2002 are employed to quantify the cross-border sales for wine and liquor between West Virginia and its five bordering states. These estimates are then used along with information concerning the tax treatment of wine and liquor in West Virginia to calculate an estimation of the revenue impacts of cross-border sales and tourism for the state. Ordinary Least Squares (OLS) estimates are presented; however, these estimates may be biased and/or inconsistent given the presence of spatial dependence between counties. To correct for these potential problems, models controlling for spatial dependence are used to get unbiased, efficient, and consistent estimations. ${ }^{6}$ Spatial dependence is analogous to serial correlation in time series studies. Just as one should correct for serial correlation, one should correct for spatial dependence in cross-sectional and panel studies.

The paper proceeds as follows: Section 2 reviews the pertinent existing literature examining alcohol consumption and cross-border sales. Section 3 discusses the tax rates in West Virginia and in each bordering state, followed by the a priori expectations based on the tax rate differentials. Section 4 presents the data, the empirical model, and the results. Concluding remarks and policy implications are offered in Section 5.

\footnotetext{
${ }^{6}$ See Cliff and Ord (1981) and Anselin (1988) for more on models of spatial dependence.
} 


\subsection{Literature Review}

\subsubsection{Alcohol Consumption Literature}

Much of the literature studying alcohol markets centers around estimating the elasticity of demand. Most of these empirical studies, such as Niskanen (1962), Hogarty and Elzinga (1972), and Clements and Johnson (1983) support the widely held view that the short-run demand for alcohol is relatively inelastic. ${ }^{7}$ Other empirical studies of the demand for alcohol have focused on specific subgroups of alcohol drinkers, finding evidence that alcohol demand may be elastic for specific individuals. Cook and Tauchen (1982) find that heavy drinkers are much more responsive to price changes than the casual drinker. ${ }^{8}$ Similarly, Saffer and Grossman (1987) find the demand for alcohol by young drinkers to be fairly elastic.

Other areas of interest in the alcohol literature concern alcohol-related problems such as health concerns, automobile accidents and injuries, and criminal activities. For instance, Cook et al. (2005) find that increases in alcohol excise taxes lead to declines in alcohol consumption and all-cause mortality rates. ${ }^{9}$ Lester (1995) finds that homicide rates are not related to various measures of access, but Scribner, Cohen, Kaplan, and Allen (1999) reach the opposite conclusion using data for New Orleans. Markowitz (2000) and Gorman et al. (1998) both suggest that spousal abuse and alcohol availability are not related. Yet, Gyimah-Brempong (2001), using various measures of criminal activity, finds evidence indicating that alcohol access does lead to increased crime. While Gruenewald et al. (1996) find evidence of a positive relationship between alcohol

\footnotetext{
${ }^{7}$ See also Young and Bielinska-Kwapisz (2002).

${ }^{8}$ See also Manning et al. (1995).

${ }^{9}$ For more on the relationship between various health issues and alcohol, see Brown and Jewell (1996), Xie et al. (2000), Tatlow et al. (2000), and Scribner, Cohen, and Farley. (1999).
} 
availability and single vehicle nighttime crashes, a proxy for alcohol-related accidents, Kelleher et al. (1996) find no such relation for vehicle fatalities of young men. ${ }^{10}$

\subsubsection{Cross-border Literature}

In addition to the areas of research discussed above, a large segment of the alcohol literature concerns cross-border sales. Before turning to the issue of cross-border alcohol sales, it is worthwhile to discuss some of the other literature related to cross-border shopping and, more generally, smuggling. The literature on smuggling defines two different, although closely related, types of smuggling. The first is organized smuggling, also known as commercial smuggling or bootlegging. Smuggling of this type involves the purchase of a good in low-tax states or in illegal markets where no taxes are paid and the resale of the good in high-tax states in illegal markets. Thursby and Thursby (2000) find empirical evidence that commercial smuggling is relevant in the cigarette market and that government policies designed to prevent this smuggling often have the reverse effect. ${ }^{11}$ The second type of smuggling, and the topic of this chapter, is cross-border shopping (or casual smuggling). Like commercial smuggling, cross-border shopping is often driven by interstate tax differentials. Cross-border shopping is simply the retail purchase of goods for consumption in a near-by low-tax state, whereas commercial smuggling involves the illegal resale of goods in high-tax states.

There are numerous theoretical models of cross-border shopping and the resulting tax competition between regions and different levels of government. Several of these studies have shown that direct tax competition causes the regions to reduce their tax rates

\footnotetext{
${ }^{10}$ Burkey (2005) provides a nice discussion of many of the issues associated with alcohol availability, using a spatial econometric model to explain many of the discrepancies in the literature.

${ }^{11}$ See also Thursby et al. (1991).
} 
below the socially efficient levels, leading to a general underprovision of public goods. Kanbur and Keen (1993) examine indirect tax competition in a partial equilibrium model in which there are two asymmetric regions behaving as Nash players. Wang (1999) modifies their model to allow one of the players to act as a Stackelberg leader. Neilson (2001) modifies Kanbur and Keen model by introducing transportation costs and the potential for border inspection.

While each of the above models assumes an evenly distributed population, Trandel (1994) and Ohsawa (1999) relax this assumption. Trandel (1994) finds that the more densely populated region imposes a higher tax rate. Ohsawa (1999) considers a case with more than two regions, where the size and positions create varying degrees of market power. Lucus (2004) examines tax competition in a federal economy where both horizontal and vertical externalities are present. He shows how the central government can act as the Stackelberg leader to internalize these externalities by through the use of matching grants.

Most empirical studies of cross-border shopping in the United States have focused on estimating the impacts of excise taxation of alcohol, cigarettes, and gasoline or on the effects of general sales taxes. Mikesell and Zorn (1986) find evidence that the temporary city sales tax enacted in Bay St. Louis for a three year period beginning in September, 1979 caused the city's sales tax base to fall by a small, but statistically significant amount. In an analysis of the Illinois sales tax, Mikesell (1971) concludes that residents of Illinois who live in a border-county are more likely to shop across the border and residents outside the state are less likely to shop in Illinois. Additionally, cross-border shopping is determined to affect types of stores differently. Convenience goods stores do 
not appear to be affected by cross-border sales, while department stores incur substantial losses in sales. In a related issue Garrett and Marsh (2002) find strong evidence of crossborder lottery shopping using county-level data from Kansas. ${ }^{12}$

Nelson (2002) uses a panel data set and a vote-maximizing empirical model to determine how states set excise tax rates on cigarettes, alcoholic beverages, motor fuel and insurance. ${ }^{13}$ He reaches four main conclusions. First, state excise tax policies on cigarettes, motor fuel, and insurance are strongly influenced by the policies in neighboring states. Second, the size of the potential cross-border markets are important determinants of tax policy for cigarettes and distilled spirits only. Third, industry lobbying played a significant role in reducing taxes on cigarettes, liquor, and insurance. Lastly, the motivation behind excise taxation may go beyond user charges; rather, excise taxation may simply be a politically inexpensive method of raising government revenue.

Whereas Nelson (2002) empirically models how states determine excise tax policy, much of the empirical research takes state taxes as exogenous and estimate by how much consumers respond to interstate tax differentials. Wales (1968) recognizes that the occurrence of cross-border shopping distorts estimates of demand elasticity. His study finds that when cross-border effects are accounted for, the elasticity of demand for alcohol approaches zero, suggesting that consumers are highly unresponsive to price changes. Coats (1995) finds that about eighty percent of the sales response to cigarette excise tax changes is due to cross-border shopping. Saba et al. (1995) developed the first

\footnotetext{
${ }^{12}$ Garrett and Marsh's (2002) results from the Kansas City area also suggest that the size of the potential cross-border market and the location of shopping centers exert strong impacts on state lottery sales. The Kansas side of the border is loosely populated while the Missouri side is well developed. Kansas residents along the border can get a larger selection of goods by crossing the border.

${ }^{13}$ See Bowman and Mikesell (1983) for a discussion of state gasoline tax rate changes during the period 1963 to 1983.
} 
microanalytic empirical analysis of cross-border shopping using cigarette market data, finding evidence that cross-border shopping affects sales in some states. Beard et al. (1997) adapt the model presented by Saba et al (1995) for use with the alcohol market; their results also suggest that cross-border shopping is a significant determinant of sales in some regions.

The previous literature clearly suggests that the occurrence of cross-border shopping can play a significant role in determining the level of tax revenues collected in a state. These studies suggest that states do face revenue competition due to differences in tax rates, as well as other factors not controlled by policy-makers (such as retail prices and locational convenience of economic centers). If the state sets its tax rates below the rates of the surrounding states, it will experience a net gain in cross-border sales, leading to an increase in the share of the state's tax revenues coming from out of state sources. However, this does not necessarily imply that overall tax revenues will rise. For example, as tax rates are reduced, more revenue may be generated due to an increase in cross-border shopping, but revenues earned on the purchases that would have occurred at the higher tax rate will decline. Thus, the total effect on tax revenues depends both on the change in cross-border shopping and the change in home-state consumption. On the other hand, if a state sets its tax rates too high, it will experience a net loss in cross-border sales, as many residents may choose to travel outside of the district to purchase some goods. This could lead to a significant decline in tax revenues. 


\subsection{Exporting Taxes Through Wine and Liquor Sales}

\subsubsection{Cross-border Sales and West Virginia}

Before estimating the net revenue effect of cross-border shopping, it is worth-while to first compare the tax treatment of wine and liquor in West Virginia and its bordering states Ohio, Pennsylvania, Maryland, Virginia, and Kentucky. The 2003 tax rates on wine and liquor were obtained from the state tax departments of Ohio, Kentucky, and Maryland, the West Virginia Alcohol Beverage Control Administration (WVABC), the Pennsylvania Liquor Control Board (PLCB), and the Virginia Department of Alcohol Beverage Control (VABC). Table 2.2 presents the tax rates on wine and liquor as of 2003 in each of these states. West Virginia, Ohio, Maryland, Virginia, and Kentucky all tax wine on a per gallon basis, although West Virginia also applies a five-percent ad valorem excise tax. West Virginia's unit tax rate exceeds that of Ohio, Maryland, and Kentucky. Virginia's per unit excise tax on wine is larger than the rate in West Virginia. In addition to the per unit excise tax in Virginia, there is also a county-imposed fourpercent ad valorem excise tax on wine. This tax is optional, but most counties, including all of those along the West Virginia border, choose to enforce it. Pennsylvania places a half-cent $(\$ 0.005)$ per-unit-proof per-gallon tax on wine, rather than the per gallon tax used in the other states mentioned. Depending on the proof of the purchased wine, an individual could pay a larger or smaller amount in taxes in Pennsylvania relative to the same purchase in West Virginia.

Of the six states of interest, only Kentucky and Maryland allow liquor to be sold by private vendors at both wholesale and retail. The 2003 tax rates on liquor in Kentucky and Maryland are \$1.92 and \$1.50, respectively. The other four states (West Virginia, 
Ohio, Pennsylvania, and Virginia) allow the sale of liquor only at state-owned, stateoperated, or state-licensed stores. The revenue in these states is generated from various taxes, fees, and net profits (earned on ad valorem mark-ups). The state mark-up in Virginia varies by volume and proof, ranging from thirty-two percent to seventy-six percent. An ad valorem excise tax of twenty percent is applied after mark-up. Pennsylvania imposes an ad valorem tax rate of $18 \%$ in addition to the state mark-up. Ohio has a per unit tax on liquor of $\$ 3.38$ per gallon. Each of the six states of concern apply the state sales tax to wine and liquor sales. The treatment of liquor sales in West Virginia is discussed in greater detail below.

Table 2.2

Effective Tax Rates for Wine and Liquor ${ }^{-}$

\begin{tabular}{|c|c|c|c|}
\hline \multirow[t]{2}{*}{ State } & \multicolumn{2}{|c|}{ Effective Tax Rates } & \multirow[t]{2}{*}{ Sales Tax } \\
\hline & Wine & Liquor & \\
\hline West Virginia $^{2}$ & $\$ 1.00 /$ gallon $+5 \%$ excise & $\begin{array}{l}28 \% \text { wholesale mark-up }+\$ 1.25 / \text { case }+ \\
5 \% \text { excise }\end{array}$ & $6.0 \%$ \\
\hline Ohio $^{2}$ & $\begin{array}{c}\$ 0.32 / \text { gallon (<28 proof) } \\
\$ 1.00 / \text { gallon (28 to } 41 \text { proof) }\end{array}$ & $\$ 3.38 /$ gallon & $6.0 \%$ \\
\hline Pennsylvania $^{3}$ & 0.5 cents/unit proof per gallon & $30 \%$ wholesale mark-up $+18 \%$ excise & $6.0 \%$ \\
\hline Maryland & $\$ 0.40 /$ gallon & $\$ 1.50 /$ gallon & $5.0 \%$ \\
\hline Virginia $^{2}$ & $\$ 1.51 /$ gallon $+4 \%$ & $\begin{array}{c}\$ 1 / \text { case }+32 \% \text { to } 76 \% \text { wholesale } \\
\text { mark-up }+20 \% \text { excise }\end{array}$ & $4.5 \%$ \\
\hline Kentucky & $\$ 0.50 /$ gallon & $\$ 1.52 /$ gallon & $6.0 \%$ \\
\hline
\end{tabular}

The West Virginia Alcohol Beverage Control Administration (WVABCA) operates as a monopoly, as it is the only legal supplier of liquor to retailers in the state. The WVABCA places a twenty-eight percent ad valorem mark-up on all sales of liquor to retail outlets plus a $\$ 1.25$ delivery charge per case. Case sizes vary substantially, ranging from as small as one unit per case to twenty units or more per case. The average price 
(after mark-up and delivery charge) of a case of liquor sold to retailers in 2004 was \$91.05. Retailers can then break the cases into individual units for sale. Liquor retailers must, at a minimum mark-up the final sale price by ten-percent, although it is common for retailers to use a mark-up of thirty-percent, so this minimum does not appear binding. Revenue from the retail mark-up is retained by the (private) licensed retailer, not the state. The state also imposes a five-percent ad valorem excise tax and six-percent sales tax on the final sale price of liquor, inclusive of the earlier mark-ups.

I now turn to my a priori expectations for the net effect of cross-border wine and liquor shopping for West Virginia. I will divide the discussion into five regions, defined by border state. Those counties in West Virginia that border Virginia are expected to experience a net gain in cross-border sales. The tax rates on wine and liquor are both higher in Virginia, suggesting that proportionately more residents of Virginia will cross the border to purchase wine and liquor than vice-versa. The net effect of cross-border shopping in each of the other regions is not as straight-forward.

The region of West Virginia bordering Kentucky is likely to experience a negative net effect due to cross-border shopping. Both states impose a per unit tax on wine, but Kentucky's is half the rate of West Virginia. While the tax rates on wine are directly comparable, this is not the case for liquor taxation. At the point of purchase, West Virginia applies a five percent excise plus the six percent sales tax to liquor sales while Kentucky imposes a $\$ 1.52$ per gallon excise plus the six percent sales tax. To get an estimate of the retail price per gallon necessary to induce some West Virginia residents to cross into Kentucky to purchase liquor, I equate the two taxes paid by the consumer and solve for price. Following this method, I determine that an average retail price of $\$ 30.40$ 
per gallon of liquor would make consumers indifferent of the place of purchase. An average price above $\$ 30.40$ would cause the total tax paid in West Virginia to exceed the $\$ 1.52$ per gallon unit tax in Kentucky. According to the American Chamber of Commerce Researchers Association (ACCRA), the average price of a $750 \mathrm{ml}$ bottle of J\&B Scotch in the Charleston, West Virginia MSA in 1998 was $\$ 20.95$. This equates to over $\$ 105$ per gallon. Thus, it appears the net effect of cross-border shopping in the region bordering Kentucky is expected to be negative.

The region bordering Maryland should exhibit similar net effects as Kentucky. The region bordering Maryland should observe a net decrease in wine sales due to crossborder shopping, since the Maryland tax is less than half of West Virginia's tax. The effect on liquor sales in this region again depends on the average retail price of liquor purchased. If the purchase price of a gallon of liquor is greater than $\$ 25$ (found by equating the total tax paid in each state), then the total tax paid per gallon in Maryland would be less than the tax paid in West Virginia. As indicated above, the average price according to ACCRA was over $\$ 105$. Similar to the Kentucky region, a negative net effect on liquor sales is expected in Maryland border-region of West Virginia.

Ohio imposes a smaller tax per unit of wine than does West Virginia. Thus, the region of West Virginia bordering Ohio is expected to experience a negative net effect on wine sales due to cross-border shopping. Following the method described above, and equating the total tax paid on a gallon of liquor in the two states, the total tax becomes smaller in Ohio at a retail price of $\$ 67.60$ per gallon. The net effect of cross-border shopping for liquor is negative; relatively more residents of West Virginia should travel into Ohio to purchase liquor. 
Pennsylvania allows the sale of wine and liquor only at state-owned stores. As such, the state earns revenue from wine and liquor sales both from taxes and mark-ups (net profits). Pennsylvania's wine tax is 0.5 cents per unit proof per gallon. If there were no mark-up on wine sales, then the tax would always be less than the West Virginia tax. If the mark-up is small, then the region bordering Pennsylvania will experience a net loss in wine sales due to cross-border sales. If the mark-up is large, the region should experience a net gain. Without knowledge of this mark-up, however, no expectation can be formed. Pennsylvania's wholesale mark-up and ad valorem excise rate applied to liquor sales are both greater than those in West Virginia. Indeed, the ad valorem excise is more than three times the rate of West Virginia. Given these comparisons, the region of West Virginia bordering Pennsylvania should observe a net increase in liquor sales due to cross-border shopping.

\subsubsection{Tourism in West Virginia}

In addition to cross-border sales, tax exporting can also result from tourism. Casual observation while watching television suggests that states have taken a specific interest in attracting tourism. Commercials showing the numerous outdoor activities and entertainment attractions in Tennessee, Ohio, and West Virginia and the night-life in Las Vegas are but a few examples of this sort of competition for tourists. The West Virginia Tourism website compiles a listing of all of the major tourist attractions in the state. There are four large gaming resorts (including dog tracks) in West Virginia. They are Wheeling Downs in Ohio county, Tri-State Casino in Kenawha county, Charles Town Races and Slots in Jefferson county, and Mountaineer Racetrack and Gaming Resort in 
Hancock county. There are also four large ski resorts in the state: Canaan Valley and Timberline in Tucker county, Snowshoe in Pocahontas county, and Winterplace in Raleigh county. West Virginia also offers an assortment of upscale resorts located throughout the state. The most famous and largest of the resorts is The Greenbrier located in Greenbrier county. There are two major universities in West Virginia, West Virginia University in Monongalia county and Marshall University in Cabell county. Universities can have the same influences as the aforementioned tourist attractions. Indeed, major university sporting events, plays, and recitals can draw in a great deal of attendance from outside of the state.

Counties with a tourist attraction are expected to exert upward pressure on wine and liquor sales. Thus, it is expected that tax revenues in counties with tourist attractions should be significantly higher relative to counties with no attractions. However, the type of consumer will likely differ depending on the tourist attraction. For example, those who attend an upscale resort may be less likely to consume large sums of liquor but prefer wines instead. Tail-gaiters at university sporting events, on the other hand, may consume more liquor than wine, although beer is probably the most common alcoholic beverage among this group. In summary, the impacts of gaming resorts, ski resorts, upscale resorts, and universities are all expected to positively influence the consumption of wine and liquor. However, their effects may be quite different on wine consumption relative to liquor consumption. 


\subsection{Methodology, Data, and Empirical Evidence}

Previous studies of cross-border shopping for alcohol have shown evidence that tax differentials drive cross-border shopping in at least some districts. For example, Beard et al. (1997) use state-level per capita beer and liquor sales to find that border-crossing is a significant determinant of beer and liquor sales in some states and that tourism significantly increases alcohol sales. The goal of this chapter is to determine whether cross-border sales and tourism are a significant factor in determining the sales of wine in liquor in the state of West Virginia at the county-level and whether this result has an economically significant impact on state revenues. I obtained data for all fifty-five counties in West Virginia for the years 1993-2002 for the empirical analysis.

The general empirical model involves regressing per capita wine or liquor sales on a vector of demographic variables, a vector of dummy variables to control for travel and tourism, a vector of border dummy variables, and a time trend. In addition to the specifications using per capita wine and liquor sales as the dependent variable, I run identical regressions with total per capita sales. Total per capita sales is the sum of per capita wine and liquor sales and per capita alcohol sales at private clubs. Demographic variables included in the regression are per capita income and the unemployment rate in the county. Data for religion, age, and race are not available at the county-level for the time period in question. County-fixed-effects could help control for these county characteristics; however, county-fixed-effects introduce multicolinearity problems with the border dummy variables and are therefore not used. I use an interstate dummy variable, equal to one if the county has a major interstate and zero otherwise, to proxy for ease of travel. I also use dummy variables to proxy for tourism; this list of variables 
includes a resort dummy, a gaming dummy, and a university dummy. Finally, to measure the effects of cross-border shopping, I include a set of border dummy variables for each border state equal to one if the county borders the state and zero otherwise. The basic empirical model can be written as follows:

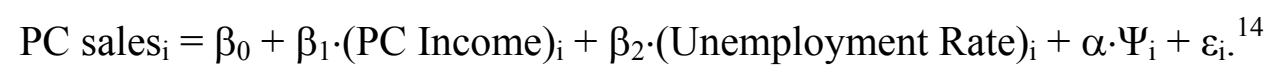

Table 2.3 presents the regression results using ordinary least squares (OLS) estimation. While the OLS estimation produces results consistent with the a priori expectations, it is not the preferred method of estimation. The consumption of alcohol (or the measurement of that consumption) in county $i$ is influenced by consumption (or measurement) patterns in other counties, so the OLS estimates may be biased, inefficient, and inconsistent. ${ }^{15}$ This dependence between cross-sectional observations is known as spatial dependence. Spatial dependence in wine and liquor sales is a reasonable assumption. For example, the location of retail centers in one county can exhibit a large influence on sales in another county.

To correct for spatial dependence in wine and liquor sales, I adapt my general regression equation (equation 2.1), to include a spatial weighting matrix. ${ }^{16}$ Spatial dependence can occur in the dependent variable or in the error component. To control for spatial dependence in the dependent variable, I use the spatial lag model:

\footnotetext{
${ }^{14}$ Additional specifications including dummy variables for those counties in the Eastern and Northern Panhandles were estimated. However, the coefficients on these dummy variables were normally insignificant and their inclusion left the other independent variables largely unaffected.

${ }^{15}$ See Anselin 1988.

${ }^{16}$ Garrett and Marsh (2002) use county level sales data in a spatial model to quantify the effect of crossborder shopping on lottery revenues in Kansas.
} 
Table 2.3

Ordinary Least Squares Regression

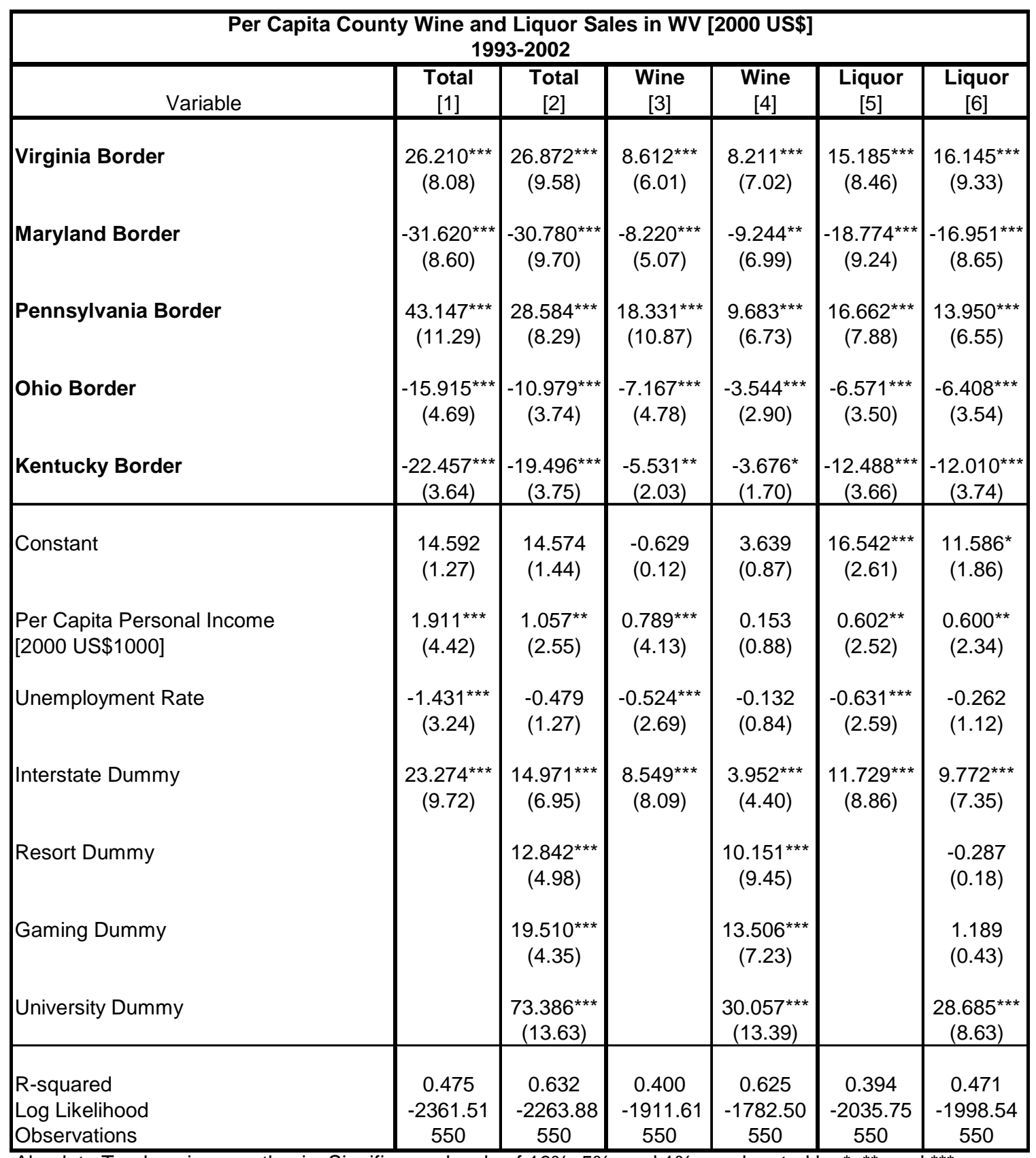

Absolute T-values in parenthesis. Significance levels of $10 \%, 5 \%$, and $1 \%$ are denoted by *, **, and ***, respectively. Regressions also include year dummies (not reported in table). 


$$
y=\rho \cdot W \cdot y+X \cdot \beta+\varepsilon,
$$

where $\mathrm{y}$ is the $\mathrm{N} \times 1$ dependent variable, $\mathrm{X}$ is the $\mathrm{N} \times \mathrm{K}$ matrix of exogenous variables, $\mathrm{W}$ is the $\mathrm{N} x \mathrm{~N}$ weighting matrix, and $\rho$ is the spatial autoregressive coefficient. To control for spatial dependence in the error term, I re-estimate my regression using the spatial error lag model:

$$
y=X \cdot \beta+\varepsilon
$$

$$
\text { where } \varepsilon=(\mathrm{I}-\lambda \cdot \mathrm{W})^{-1} \cdot v \text {, }
$$

where $\lambda$ is the unobserved spatial error correlation coefficient and $v$ is the $\mathrm{N} x 1$ vector of IID random variables component of the error terms.

The results from the spatial lag and spatial error lag models can be found in Table 2.4 and Table 2.5 , respectively. The signs of the coefficients in all specifications are consistent with my a priori expectations, although not all variables are significant. An increase in per capita personal income has a positive effect on both wine and liquor sales. A $\$ 1000$ increase in per capita income in county $i$ leads to an increase in total per capita sales by a little more than $\$ 1.00$. Although not always significant, the unemployment rate varies negatively with wine and liquor sales: a one percent increase in the unemployment rate of county $i$ causes total sales to fall by about $\$ 0.55$ per person. The presence of an interstate in a county, which decreases travel costs, significantly increases total sales, leading to an increase of about $\$ 14.00$.

Tourism is found to increase wine and liquor sales, consistent with prior studies. The presence of an upscale resort increases wine sales by about $\$ 10$. However, liquor 
Table 2.4

Spatial Autoregressive Model Weighting Matrix: Geographic Neighbors

\begin{tabular}{|c|c|c|c|c|c|c|}
\hline \multicolumn{7}{|c|}{$\begin{array}{l}\text { Per Capita County Wine and Liquor Sales in WV [2000 US\$] } \\
\qquad 1993-2002\end{array}$} \\
\hline Variable & $\begin{array}{c}\text { Total } \\
{[1]}\end{array}$ & $\begin{array}{c}\text { Total } \\
{[2]}\end{array}$ & $\begin{array}{c}\text { Wine } \\
{[3]}\end{array}$ & $\begin{array}{c}\text { Wine } \\
{[4]}\end{array}$ & $\begin{array}{l}\text { Liquor } \\
{[5]}\end{array}$ & $\begin{array}{l}\text { Liquor } \\
{[6]}\end{array}$ \\
\hline Virginia Border & $\begin{array}{c}28.318^{\star \star \star} \\
(8.60)\end{array}$ & $\begin{array}{c}27.868^{\star \star \star} \\
(12.53)\end{array}$ & $\begin{array}{c}9.484^{\star \star \star} \\
(7.15)\end{array}$ & $\begin{array}{c}8.550 * * * \\
(7.79)\end{array}$ & $\begin{array}{c}15.822^{\star \star \star} \\
(9.58)\end{array}$ & $\begin{array}{c}16.434^{\star \star \star} \\
(10.14)\end{array}$ \\
\hline Maryland Border & $\begin{array}{c}-32.753^{\star \star \star} \\
(9.38)\end{array}$ & $\begin{array}{c}-31.669 * \star \star \\
(10.25)\end{array}$ & $\begin{array}{c}-8.149 * \star \star \\
(5.26)\end{array}$ & $\begin{array}{c}-9.297^{\star \star \star} \\
(7.23)\end{array}$ & $\begin{array}{c}-19.665^{\star \star \star} \\
(9.98)\end{array}$ & $\begin{array}{c}-17.456^{\star \star \star} \\
(9.12)\end{array}$ \\
\hline Pennsylvania Border & $\begin{array}{c}50.503^{\star \star \star} \\
(12.79)\end{array}$ & $\begin{array}{c}33.169 \star \star \star \star \\
(9.06)\end{array}$ & $\begin{array}{c}20.961^{\star * *} \\
(13.35)\end{array}$ & $\begin{array}{c}11.272^{\star \star \star} \\
(8.24)\end{array}$ & $\begin{array}{c}18.373^{\star \star \star} \\
(9.08)\end{array}$ & $\begin{array}{l}14.914^{\star * \star} \\
(7.21)\end{array}$ \\
\hline Ohio Border & $\begin{array}{c}-16.373^{\star \star \star} \\
(4.67)\end{array}$ & $\begin{array}{c}-11.296^{\star \star \star} \\
(5.74)\end{array}$ & $\begin{array}{c}-7.294^{\star \star \star} \\
(5.41)\end{array}$ & $\begin{array}{c}-3.652^{\star \star \star} \\
(3.25)\end{array}$ & $\begin{array}{c}-6.980 * \star * \\
(4.22)\end{array}$ & $\begin{array}{c}-6.625^{\star \star \star} \\
(4.02)\end{array}$ \\
\hline Kentucky Border & $\begin{array}{c}-25.051^{\star \star \star} \\
(4.18)\end{array}$ & $\begin{array}{c}-20.991^{\star \star \star} \\
(4.38)\end{array}$ & $\begin{array}{c}-6.771^{\star \star \star} \\
(2.63)\end{array}$ & $\begin{array}{c}-4.296 * \star \\
(2.06)\end{array}$ & $\begin{array}{c}-12.978^{\star \star \star} \\
(3.98)\end{array}$ & $\begin{array}{c}-12.273^{\star \star \star} \\
(3.96)\end{array}$ \\
\hline Rho & $\begin{array}{c}-0.286 * \star \star \\
(5.16)\end{array}$ & $\begin{array}{c}-0.159^{* * *} \\
(3.09)\end{array}$ & $\begin{array}{c}-0.263^{\star \star \star} \\
(7.40)\end{array}$ & $\begin{array}{c}0.136 * * \star \\
(5.81)\end{array}$ & $\begin{array}{c}-0.163^{\star \star \star} \\
(6.31)\end{array}$ & $\begin{array}{c}-0.082^{\star \star \star} \\
(4.77)\end{array}$ \\
\hline Constant & $\begin{array}{c}29.308^{*} \\
(1.79)\end{array}$ & $\begin{array}{c}23.132 \\
(1.64)\end{array}$ & $\begin{array}{l}3.993^{*} \\
(1.93)\end{array}$ & $\begin{array}{c}5.740^{\star \star \star} \\
(2.61)\end{array}$ & $\begin{array}{c}20.744^{\star \star \star} \\
(17.57)\end{array}$ & $\begin{array}{c}13.840 \text { *** } \\
(5.78)\end{array}$ \\
\hline $\begin{array}{l}\text { Per Capita Personal Income } \\
\text { [2000 US\$1000] }\end{array}$ & $\begin{array}{l}1.799 * \star \\
(2.56)\end{array}$ & $\begin{array}{l}1.020 \\
(1.24)\end{array}$ & $\begin{array}{l}0.701^{\star \star \star} \\
(7.02)\end{array}$ & $\begin{array}{l}0.143^{\star \star} \\
(2.34)\end{array}$ & $\begin{array}{c}0.609 * * * \\
(2.89)\end{array}$ & $\begin{array}{c}0.605^{\star \star \star} \\
(3.86)\end{array}$ \\
\hline Unemployment Rate & $\begin{array}{c}-1.525^{\star \star \star} \\
(3.37)\end{array}$ & $\begin{array}{l}-0.589 * \\
(1.84)\end{array}$ & $\begin{array}{c}-0.560 * \star \star \\
(3.28)\end{array}$ & $\begin{array}{l}-0.172 \\
(1.17)\end{array}$ & $\begin{array}{c}-0.644^{\star \star *} \\
(2.95)\end{array}$ & $\begin{array}{l}-0.281 \\
(1.28)\end{array}$ \\
\hline Interstate Dummy & $\begin{array}{l}22.646^{\star \star *} \\
(9.78)\end{array}$ & $\begin{array}{c}14.909 * \star * \\
(7.47)\end{array}$ & $\begin{array}{c}8.597^{\star \star *} \\
(8.60)\end{array}$ & $\begin{array}{l}4.037^{\star * \star} \\
(4.66)\end{array}$ & $\begin{array}{c}11.455^{\star \star \star} \\
(9.09)\end{array}$ & $\begin{array}{c}9.704^{\star \star \star} \\
(7.54)\end{array}$ \\
\hline Resort Dummy & & $\begin{array}{c}12.874^{\star \star \star} \\
(5.16)\end{array}$ & & $\begin{array}{l}10.237^{\star \star \star} \\
(9.81)\end{array}$ & & $\begin{array}{l}-0.293 \\
(0.19)\end{array}$ \\
\hline Gaming Dummy & & $\begin{array}{c}18.790 * \star \star \\
(9.10)\end{array}$ & & $\begin{array}{l}12.651^{\star \star \star} \\
(8.15)\end{array}$ & & $\begin{array}{l}1.110 \\
(0.50)\end{array}$ \\
\hline University Dummy & & $\begin{array}{c}69.057^{\star * \star} \\
(12.91)\end{array}$ & & $\begin{array}{c}28.621 * \star \star \\
(13.26)\end{array}$ & & $\begin{array}{l}27.708^{\star \star *} \\
(8.58)\end{array}$ \\
\hline R-squared & 0.479 & 0.631 & 0.392 & 0.623 & 0.400 & 0.472 \\
\hline Log Likelihood & -2347.41 & -2258.87 & -1900.82 & -1778.63 & -2031.37 & -1997.37 \\
\hline Observations & 550 & 550 & 550 & 550 & 550 & 550 \\
\hline
\end{tabular}

Absolute T-values in parenthesis. Significance levels of $10 \%, 5 \%$, and $1 \%$ are denoted by *, ${ }^{\star \star}$, and ***, respectively. Regressions also include year dummies (not reported in table). 
Table 2.5

Spatial Error Model

Weighting Matrix: Geographic Neighbors

\begin{tabular}{|c|c|c|c|c|c|c|}
\hline \multicolumn{7}{|c|}{$\begin{array}{l}\text { Per Capita County Wine and Liquor Sales in WV [2000 US\$] } \\
\qquad 1993-2002\end{array}$} \\
\hline Variable & $\begin{array}{c}\text { Total } \\
{[1]}\end{array}$ & $\begin{array}{c}\text { Total } \\
{[2]}\end{array}$ & $\begin{array}{c}\text { Wine } \\
{[3]}\end{array}$ & $\begin{array}{c}\text { Wine } \\
{[4]}\end{array}$ & $\begin{array}{l}\text { Liquor } \\
{[5]}\end{array}$ & $\begin{array}{l}\text { Liquor } \\
{[6]}\end{array}$ \\
\hline Virginia Border & $\begin{array}{c}26.482^{\star \star \star} \\
(9.71)\end{array}$ & $\begin{array}{c}27.134^{\star \star \star} \\
(10.92)\end{array}$ & $\begin{array}{c}9.181^{\star \star *} \\
(7.67)\end{array}$ & $\begin{array}{c}8.332^{\star * *} \\
(8.00)\end{array}$ & $\begin{array}{c}15.106^{\star \star \star} \\
(9.41)\end{array}$ & $\begin{array}{c}16.179 * \star \star \\
(10.12)\end{array}$ \\
\hline Maryland Border & $\begin{array}{c}-28.463^{\star \star \star} \\
(9.28)\end{array}$ & $\begin{array}{c}-30.380 \text { *** } \\
(10.86)\end{array}$ & $\begin{array}{c}-6.525^{\star \star} \\
(4.83)\end{array}$ & $\begin{array}{c}-8.863^{\star \star \star} \\
(7.60)\end{array}$ & $\begin{array}{c}-18.710^{\star \star \star} \\
(9.91)\end{array}$ & $\begin{array}{c}-17.202^{\star \star \star} \\
(9.31)\end{array}$ \\
\hline Pennsylvania Border & $\begin{array}{c}45.681^{\star \star *} \\
(14.89)\end{array}$ & $\begin{array}{c}31.946 * \star \star \\
(10.37)\end{array}$ & $\begin{array}{c}19.339 \star \star \star \\
(14.49)\end{array}$ & $\begin{array}{c}10.982^{\star \star *} \\
(8.58)\end{array}$ & $\begin{array}{c}17.229 * \star \star \\
(8.93)\end{array}$ & $\begin{array}{c}14.722^{\star \star \star} \\
(7.38)\end{array}$ \\
\hline Ohio Border & $\begin{array}{c}-16.522^{\star \star \star} \\
(6.11)\end{array}$ & $\begin{array}{c}-12.303^{\star \star \star} \\
(4.90)\end{array}$ & $\begin{array}{c}-6.899 * * * \\
(5.73)\end{array}$ & $\begin{array}{c}-3.764^{\star \star \star} \\
(3.62)\end{array}$ & $\begin{array}{c}-7.107^{\star \star \star} \\
(4.65)\end{array}$ & $\begin{array}{c}-6.931^{\star * \star} \\
(4.38)\end{array}$ \\
\hline Kentucky Border & $\begin{array}{c}-19.722^{\star \star \star} \\
(3.67)\end{array}$ & $\begin{array}{c}-21.525^{\star \star \star} \\
(4.56)\end{array}$ & $\begin{array}{c}-5.843^{\star \star} \\
(2.50)\end{array}$ & $\begin{array}{c}-5.172^{\star \star \star} \\
(2.62)\end{array}$ & $\begin{array}{c}-11.508^{\star \star \star} \\
(3.66)\end{array}$ & $\begin{array}{c}-12.068^{\star \star \star} \\
(3.96)\end{array}$ \\
\hline Lambda & $\begin{array}{c}-0.347^{\star \star *} \\
(13.87)\end{array}$ & $\begin{array}{c}-0.233^{* * *} \\
(8.50)\end{array}$ & $\begin{array}{c}-0.369 * \star \star \\
(5.60)\end{array}$ & $\begin{array}{c}-0.234^{\star \star \star} \\
(7.50)\end{array}$ & $\begin{array}{c}-0.131^{\star \star \star} \\
(3.96)\end{array}$ & $\begin{array}{c}-0.090^{\star \star *} \\
(4.17)\end{array}$ \\
\hline Constant & $\begin{array}{c}20.332^{\text {}} \\
(3.47)\end{array}$ & $\begin{array}{c}15.842^{\star \star \star} \\
(3.04)\end{array}$ & $\begin{array}{l}2.437 \\
(0.76)\end{array}$ & $\begin{array}{l}3.893^{*} \\
(1.71)\end{array}$ & $\begin{array}{c}17.299 * * * \\
(9.66)\end{array}$ & $\begin{array}{c}11.549 * * * \\
(4.78)\end{array}$ \\
\hline $\begin{array}{l}\text { Per Capita Personal Income } \\
\text { [2000 US\$1000] }\end{array}$ & $\begin{array}{l}1.581^{\star \star \star} \\
(12.70)\end{array}$ & $\begin{array}{l}1.077^{\star \star \star} \\
(10.05)\end{array}$ & $\begin{array}{c}0.550 * \star \star \\
(7.49)\end{array}$ & $\begin{array}{l}0.146^{\star \star \star} \\
(8.79)\end{array}$ & $\begin{array}{c}0.593^{\star \star \star} \\
(2.76)\end{array}$ & $\begin{array}{c}0.638^{\star \star \star} \\
(4.24)\end{array}$ \\
\hline Unemployment Rate & $\begin{array}{c}-1.436 * \star \star \\
(3.80)\end{array}$ & $\begin{array}{l}-0.541 \\
(1.59)\end{array}$ & $\begin{array}{c}-0.483^{\star \star \star} \\
(2.85)\end{array}$ & $\begin{array}{l}-0.132 \\
(0.94)\end{array}$ & $\begin{array}{c}-0.655^{\star \star \star} \\
(3.06)\end{array}$ & $\begin{array}{l}-0.288 \\
(1.33)\end{array}$ \\
\hline Interstate Dummy & $\begin{array}{l}22.039 * * * \\
(10.24)\end{array}$ & $\begin{array}{c}13.386^{\star \star \star} \\
(6.576)\end{array}$ & $\begin{array}{c}8.954^{\star \star \star} \\
(9.57)\end{array}$ & $\begin{array}{c}3.791^{\star * \star} \\
(4.50)\end{array}$ & $\begin{array}{c}11.169 * \star \star \\
(9.08)\end{array}$ & $\begin{array}{c}9.327^{\star \star \star} \\
(7.33)\end{array}$ \\
\hline Resort Dummy & & $\begin{array}{c}12.196^{\star \star \star} \\
(5.02)\end{array}$ & & $\begin{array}{l}9.904^{\star \star \star} \\
(9.78)\end{array}$ & & $\begin{array}{l}-0.360 \\
(0.23)\end{array}$ \\
\hline Gaming Dummy & & $\begin{array}{c}18.388^{\star \star *} \\
(4.62)\end{array}$ & & $\begin{array}{c}12.198^{* \star \star} \\
(7.21)\end{array}$ & & $\begin{array}{l}0.779 \\
(0.34)\end{array}$ \\
\hline University Dummy & & $\begin{array}{c}72.101^{\star \star *} \\
(13.68)\end{array}$ & & $\begin{array}{c}29.771^{\star \star \star} \\
(13.57)\end{array}$ & & $\begin{array}{c}28.231^{\star \star *} \\
(8.67)\end{array}$ \\
\hline R-squared & 0.513 & 0.645 & 0.452 & 0.638 & 0.402 & 0.474 \\
\hline Log Likelihood & -2349.40 & -2258.03 & -1896.22 & -1776.56 & -2033.74 & -1997.72 \\
\hline Observations & 550 & 550 & 550 & 550 & 550 & 550 \\
\hline
\end{tabular}

Absolute T-values in parenthesis. Significance levels of $10 \%, 5 \%$, and $1 \%$ are denoted by ${ }^{*}$, ${ }^{\star}$, and ${ }^{* \star *}$, respectively. Regressions also include year dummies (not reported in table). 
sales are not influenced by upscale resorts. These two results may be explained by examining the characteristics of the patrons of upscale resorts. These patrons are normally fairly wealthy, and wealthy individuals can be viewed as preferring wines to hard liquor. Surprisingly, the presence of a gaming resort has little impact on liquor sales while exerting a strong influence on wine sales, increasing wine sales by about $\$ 12$ per capita. The two counties with large universities, Monongalia and Cabell counties, experience about a $\$ 28$ increase in both per capita wine sales and per capita liquor sales.

Cross-border shopping for wine and liquor is also found to be significant for all regions, normally at the $1 \%$-significance level. Counties in the Ohio, Maryland, and Kentucky regions were all expected to experience a net loss in per capita wine sales due to cross-border shopping. Indeed, this is what we observe from the data. Counties in the Ohio region lose about $\$ 3.70$ per capita in wine sales; those in the Maryland region lose about $\$ 9.00$ per capita; and the Kentucky region loses $\$ 4.00$ - $\$ 5.00$ per capita in annual wine sales. Counties bordering Virginia were expected to experience a net gain in crossborder shopping for wine; this too is supported by the results. Counties in the Virginia border region, even after controlling for tourism, observe a net increase in per capita wine sales of more than $\$ 8.00$. No a priori expectations for the net effect along the Pennsylvania border could be established without knowledge of the mark-up on wine in Pennsylvania. The results in Table 2.4 and 2.5 suggest that the mark-up is sizable since WV counties in this region experience an $\$ 11.00$ net increase in per capita wine sales.

The results for cross-border shopping for liquor are quite similar to those of wine. Again, the a priori expectations are supported. The Virginia and Pennsylvania regions were expected to experience a net increase in liquor sales from cross-border shopping. 
The coefficient on the Virginia border dummy exceeds $\$ 16$ with the coefficient on the Pennsylvania border dummy slightly smaller at about $\$ 14.80$ per capita. The results for Ohio, Maryland, and Kentucky were said to depend on the mark-up on liquor sales in West Virginia, although the net effect in the Maryland and Kentucky region are likely negative since the per unit tax rates are fairly low in those states. The results suggest a net loss in liquor sales in all three regions. Furthermore, the effect is smallest for the Ohio region, which should be expected given that the tax rate in Ohio is over double the rates in Maryland and Kentucky.

Table 2.6 presents the estimated economic impacts of cross-border liquor sales based on the spatial lag model coefficients. An equivalent table of the estimated effects of cross-border wine sales is not possible without further knowledge on the quantity of wine sold, since the wine excise tax is per unit. While total liquor tax revenue due to cross-border shopping and tourism comprises only a small percentage (0.03 percent) of total state and local revenues, it appears that the cross-border effect is large relative to total liquor tax revenue. For instance, over fifty-percent of all revenues from the wholesale mark-up is generated in the Virginia and Pennsylvania regions. The other three state-regions reduce revenues by more than negative forty-five percent as a percent of total mark-up revenue, canceling out many of the gains from the Pennsylvania and Virginia regions. The presence of a university accounts for nearly twenty-percent of state revenues from the mark-up on liquor. This suggests that revenue from liquor taxation is highly dependent on interstate tax differentials and tourism. 
Table 2.6

Estimated Economic Impacts of Liquor Taxation ${ }^{1}$

Based on Spatial Lag Estimates

Fiscal Year Ending 2002

\begin{tabular}{|c|c|c|c|c|c|c|c|}
\hline & $\begin{array}{l}\text { Impact on } \\
\text { Total Sales }\end{array}$ & $\begin{array}{l}\text { Excise Tax } \\
\text { Revenue }\end{array}$ & $\begin{array}{l}\text { Sales Tax } \\
\text { Revenue }\end{array}$ & $\begin{array}{l}\text { Mark-up } \\
\text { Revenue }\end{array}$ & $\begin{array}{c}\text { Share of Mark-up } \\
\text { Revenue }\end{array}$ & $\begin{array}{c}\text { Sum of Revenue } \\
\text { From Liquor }\end{array}$ & $\begin{array}{c}\text { Share of State \& } \\
\text { Local Revenue }\end{array}$ \\
\hline Gaming Counties & $\$ 354,169$ & $\$ 17,708$ & $\$ 21,250$ & $\$ 212,842$ & $1.90 \%$ & $\$ 251,800$ & $0.0023 \%$ \\
\hline & & & & & & & $0.0000 \%$ \\
\hline VA Border Counties & $\$ 6,192,019$ & $\$ 309,601$ & $\$ 371,521$ & $\$ 3,721,165$ & $33.17 \%$ & $\$ 4,402,287$ & $0.0405 \%$ \\
\hline PA Border Counties & $\$ 3,493,321$ & $\$ 174,666$ & $\$ 209,599$ & $\$ 2,099,352$ & $18.71 \%$ & $\$ 2,483,617$ & $0.0229 \%$ \\
\hline KY Border Counties & $-\$ 853,599$ & $-\$ 42,680$ & $-\$ 51,216$ & $-\$ 512,980$ & $-4.57 \%$ & $-\$ 606,876$ & $-0.0056 \%$ \\
\hline Total Border Effect & $\$ 1,031,809$ & $\$ 51,590$ & $\$ 61,909$ & $\$ 620,077$ & $5.53 \%$ & $\$ 733,576$ & $0.0068 \%$ \\
\hline Total Effect & $\$ 4,673,741$ & $\$ 233,687$ & $\$ 280,424$ & $\$ 2,808,739$ & $25.03 \%$ & $\$ 3,322,850$ & $0.0306 \%$ \\
\hline
\end{tabular}

${ }^{1}$ Estimates based on a $30 \%$ retail mark-up. 


\subsection{Conclusion}

Consistent with the empirical findings of Beard et al. (1997), the results of this chapter indicate that cross-border shopping for wine and liquor are significant determinants of sales. Wine and liquor tax rate differentials encourage some consumers living on the border to save money by traveling across a state border to purchase alcohol. West Virginia counties along the Virginia and Pennsylvania borders, where home tax rates are relatively lower, are shown to experience a net increase in wine and liquor sales while those along the Kentucky, Ohio, and Maryland borders, where home tax rates are relatively higher, experience a net decrease in sales. It is estimated that over fifty percent of all government revenue collected from the mark-up on liquor sales is generated from the Pennsylvania and Virginia border regions, although much of that revenue is cancelled out by the other three border regions. Additionally, the presence of universities appears to account for twenty percent of this mark-up revenue.

Given these results, state politicians should take measures to encourage residents of neighboring states to cross-border shop and to encourage tourism. Politicians in West Virginia appear to be following this general rule. Much of the growth in the state is occurring in the Eastern and Northern Panhandles, where the potential for cross-border shopping is the greatest. For instance, the state recently encouraged Cabela's to open a large store in the Northern Pan-handle just off of a major interstate. Although the store is located in West Virginia, it is expected that the majority of its sales will go to crossborder shoppers residing in Ohio and Pennsylvania. Politicians also seem to have realized the potential revenue gains to be had from tourist activities as many states, 
including West Virginia, run television commercials in nearby states informing viewers of all the attractions available in the state.

While the estimated revenue effects of cross-border shopping and tourism discussed here are significant, they are likely only a small share of the total impact. When consumers travel into the state, for either tourism or shopping, they do not only buy wine and liquor. Visitors to the state also contribute to tax revenue through their purchases of hotel rooms, gasoline, and food, as well as many other goods. Thus, the total effect of cross-border shopping and tourism is likely a large multiple of the estimates presented here. Although the potential revenue gains of tax exporting appear quite large, the main driving force behind cross-border shopping remains unclear. Consumers may decide to shop across the border due to interstate tax differentials on one particular good or class of goods, such as alcohol or groceries, but purchase other goods simply out of convenience. Thus, an interesting and much needed extension of the literature on cross-border shopping concerns this driving force. A solid case has been made suggesting that state revenues can increase substantially due to cross-border sales; the next step is to determine the best method of maximizing this revenue effect. 


\section{Chapter 3 \\ Excise Taxation and Product Quality: The Gasoline Market}

\subsection{Introduction}

Standard tax theory shows that as the tax rate rises, individuals will purchase less of the taxed good or resource. This quantity substitution, however, is not the only margin on which individuals can act to minimize their tax liability. Barzel (1976) explains that individuals may also alter their purchases of quality in response to changes in the tax rate. He theorized that for unit taxation individuals will substitute away from the taxed attribute of the good (which is quantity) and into its untaxed attribute (which is quality). Barzel's theory suggests that while both per-unit and ad valorem taxes lead to a decline in product sales, per-unit taxes will also lead to an increase in average product quality. An alternative explanation of this quality substitution can be drawn from the Alchian and Allen (1967) theorem because the imposition of a per-unit tax (a fixed fee) causes the price of the higher-quality version of a good to fall relative to a lower-quality substitute. Ad valorem taxes, however, do not alter the relative prices of the different quality levels of the product and, thus, do not impact the purchase of quality. ${ }^{17}$

While Barzel's idea is both novel and widely cited, it has received limited support empirically, with nearly all of the tests having been conducted in the cigarette market. Indeed, only Barzel's original article attempted to test his theory in a market other than cigarettes. ${ }^{18}$ While he found empirical support for his theory in the cigarette market, his results were inconclusive in the markets for gasoline and alcohol. The goal of this

\footnotetext{
${ }^{17}$ See Borcherding and Silberberg (1978), Umbeck (1980), Leffler (1982), Bertonazzi, Maloney, and McCormick (1993), Cowen and Tabarrok (1995), and Razzolini, Shughart, and Tollison (2003) for more detailed discussions of Barzel's theorem and the Alchian and Allen theorem.
} 
chapter is to reexamine the gasoline market using data that was not available when Barzel first analyzed this market, allowing for a better empirical model. This reexamination of Barzel's theory is important because there is a need to determine whether the theory is unique to the cigarette market or whether it can be applied more generally. As will be explained in the next section of the paper, Barzel's model is inherently biased toward rejecting his theory, which may explain his inability to find evidence of quality substitution in the market for gasoline. The method used in this chapter corrects this bias.

The paper proceeds as follows. In the next Section, I review the previous empirical literature, making note of the drawbacks of Barzel's original method and the benefits of the model used here. Section 3 presents the empirical model used in this study and discusses the results. Concluding remarks are offered in Section 4.

\subsection{A Review of the Empirical Literature}

Barzel originally tested his hypothesis in the cigarette market using data from 1954 to 1972. While his hypothesis was that state per unit cigarette taxes should increase the quality of cigarettes, this was impossible to test directly without objective data on the quality of cigarettes. Instead, Barzel relied on an indirect test using the price of cigarettes. His model assumed that the full burden of the tax would fall on consumers, so the retail price of cigarettes would increase by the full amount of the tax. Thus, if the imposition of a unit tax also causes an increase in product quality, the price change resulting from the unit tax should be greater than the amount of the unit tax itself

\footnotetext{
${ }^{18}$ In a related analysis, Barzel and Hall (1977) find evidence of quality substitution in response to import quotas on crude oil.
} 
(reflecting also the value of the quality improvement). This can be illustrated by the following equation:

$$
\Delta \mathrm{P}=\mathrm{T}+\Delta \mathrm{V}
$$

where $\Delta \mathrm{P}$ is the observed after-tax price change, $\mathrm{T}$ is the unit tax, and $\Delta \mathrm{V}$ is the value of the change in product quality.

The following numerical example may aid in this discussion. If a twenty cent unit tax caused the price to rise by twenty-five cents, Barzel would attribute this difference to an increase in product quality valued at five cents. However, as is discussed by Barzel in his paper, his results are critically sensitive to his assumption that the full burden of the unit tax falls on consumers. If consumers bear less than the full burden of the tax, which depends on the relative elasticities of demand and supply, increases in quality may go unmeasured in Barzel's model. Consider the same twenty cent unit tax and same increase in product quality valued at five cents discussed above, but assume instead that consumers and producers equally share the burden of the tax. The observed price increase is only fifteen cents, potentially leading to the rejection of the theory when it is actually true.

Barzel tested his theory with the following empirical model:

$$
P_{i t}=\alpha_{0}+\alpha_{1} \text { TAX }_{i t}+\alpha_{2} \text { NHTAX }_{i t}+\alpha_{3} \text { DISTANCE }_{i}+\text { year dummies }+\varepsilon_{i t}
$$

where $\mathrm{P}_{\mathrm{it}}$ is the average retail price per pack of cigarettes in state $i$ and year $t, \mathrm{TAX}_{\mathrm{it}}$ is the per unit tax on cigarettes in state $i$ and year $t$, NHTAX $_{\text {it }}$ is the product of a dummy variable for New Hampshire with $\mathrm{TAX}_{\mathrm{it}}$, DISTANCE $\mathrm{i}$ is the road distance from North 
Carolina to the largest metropolitan area in state $i$, and also included in the regression is a set of year dummy variables.

Barzel's test of his hypothesis that unit taxation leads to increased product quality centered on whether the coefficient on the TAX variable is greater than one. Additionally, to test the hypothesis that a specific ad valorem tax causes a quality reduction, a separate variable for New Hampshire was included, as it was the only state to levy a specific ad valorem tax on cigarettes. Barzel interpreted his empirical results, reproduced in Table 3.1, as supportive of both of his hypotheses, as the coefficient on the TAX variable was significantly greater than one, and the coefficient on the New Hampshire variable was negative and significant.

Johnson (1978) refined Barzel's model by adding state dummy variables to control for any state specific differences in the retail prices of cigarettes. Johnson's model can be represented as:

$$
P_{i t}=\alpha_{0}+\alpha_{1} \text { TAX }_{i t}+\alpha_{2} \text { NHTAX } i t+\text { year dummies }+ \text { state dummies }+\varepsilon_{i t}
$$

His model was also estimated using data from 1954-1972. Johnson pointed out that Barzel had incorrectly structured the test of the New Hampshire coefficient, and that Barzel's results had in fact rejected his own hypothesis. The structure of the New Hampshire variable is such that it shows the marginal impact of New Hampshire's ad valorem cigarette tax. Barzel had tested whether the coefficient on the New Hampshire variable was significantly less than zero, while Johnson argued that the correct test is that the sum of this coefficient and the coefficient on the TAX variable was less than one. A test of whether the New Hampshire coefficient is negative is a test of whether the specific ad valorem tax has a different impact than a similar unit tax, while a test of whether the 
Table 3.1

Summary of Previous Empirical Results ${ }^{1}$

\begin{tabular}{|c|c|c|c|}
\hline \multicolumn{2}{|c|}{ Barzel's Results } & \multicolumn{2}{|c|}{ Johnson's Results } \\
\hline Constant & $\begin{array}{c}14.801 \\
(73.564)\end{array}$ & Constant & $\begin{array}{l}13.651 \\
(31.08)\end{array}$ \\
\hline TAX & $\begin{array}{c}1.065 \\
(101.439)\end{array}$ & TAX & $\begin{array}{c}1.101 \\
(87.028)\end{array}$ \\
\hline NHTAX & $\begin{array}{l}-0.072 \\
(5.078)\end{array}$ & NHTAX & $\begin{array}{l}-0.503 \\
(3.156)\end{array}$ \\
\hline DISTANCE & $\begin{array}{c}0.011 \\
(3.072)\end{array}$ & & \\
\hline $\begin{array}{l}\text { State Dummy Variables } \\
\text { Year Dummy Variables }\end{array}$ & $\begin{array}{l}\text { Yes } \\
\text { No }\end{array}$ & $\begin{array}{l}\text { State Dummy Variables } \\
\text { Year Dummy Variables }\end{array}$ & $\begin{array}{l}\text { Yes } \\
\text { Yes }\end{array}$ \\
\hline R-squared & 0.93 & R-squared & 0.965 \\
\hline Observations & 931 & Observations & 1,162 \\
\hline \multicolumn{2}{|c|}{ Sumner and Ward's Results } & \multicolumn{2}{|c|}{ Sobel and Garrett's Results } \\
\hline Constant & $\begin{array}{l}-0.034 \\
(0.670)\end{array}$ & Constant & $\begin{array}{l}62.810 \\
(0.845)\end{array}$ \\
\hline$\triangle \mathrm{TAX}$ & $\begin{array}{c}0.928 \\
(25.792)\end{array}$ & UNIT TAX & $\begin{array}{c}0.327 \\
(2.007)\end{array}$ \\
\hline$\Delta \Pi$ & $\begin{array}{l}8.228 \\
(6.480)\end{array}$ & SALES TAX & $\begin{array}{l}-0.344 \\
(0.389)\end{array}$ \\
\hline$\Delta \mathrm{t} \cdot \Sigma(\Delta \Pi)$ & $\begin{array}{c}2.469 \\
(3.691)\end{array}$ & Per Capita Income & $\begin{array}{l}0.0003 \\
(0.073)\end{array}$ \\
\hline$\Delta \mathrm{W}$ & $\begin{array}{l}1.020 \\
(9.151)\end{array}$ & Unemployment Rate & $\begin{array}{l}-0.739 \\
(0.763)\end{array}$ \\
\hline State Dummy Variables & No & State Dummy Variables & Yes \\
\hline Year Dummy Variables & No & Year Dummy Variables & Yes \\
\hline R-squared & 0.744 & R-squared & 0.552 \\
\hline Observations & 784 & Observations & 255 \\
\hline
\end{tabular}

${ }^{1}$ Absolute t-ratios in parenthesis. Results from Barzel, Johnson, and Sumner and Ward based on indirect test while those from Sobel and Garrett are from a direct test of the theory. 
sum of the coefficients is less than one is a test of whether the specific ad valorem tax lowers product quality. After including state dummy variables, Johnson's results supported those of Barzel, even for the New Hampshire variable. Reproductions of Johnson's results are also given in Table 3.1.

Sumner and Ward (1981) further extended Barzel's model by adjusting for the impact of backlogged inflation. Their idea was that an increase in the cigarette tax presents an opportunity for cigarette retailers to adjust prices to reflect all inflation since the last tax change. Thus, Sumner and Ward provide an alternative explanation of why prices may rise by more than the amount of the tax. Their model, which adjusted for this phenomenon, can be written:

$$
\Delta P_{i t}=\alpha_{0}+\alpha_{1} \Delta T A X_{i t}+\alpha_{2} \Delta \prod_{t}+\alpha_{4} \Delta t_{i t} \bullet \sum_{k=m+1}^{t}\left(\Delta \prod_{k}\right)+\alpha_{5} \Delta W_{t}+\varepsilon_{i t}
$$

where all values are now in nominal terms, and their first differences are used. Their model was estimated using data from 1955-1976. In this model, $\mathrm{W}_{\mathrm{t}}$ is the wholesale price of cigarettes, $\Pi_{\mathrm{k}}$ is the consumer price index, and the summation term measures the cumulative inflation since the last state tax increase. The results of this model are also reproduced in Table 3.1. Sumner and Ward reject Barzel's hypothesis by finding a coefficient on the TAX variable strictly less than one. Thus, they conclude that unit taxes do not have a positive impact on product quality. While no separate variable was included for New Hampshire, the residuals for this state were not abnormal, leading to their second conclusion that the impacts of ad valorem taxes and unit taxes are not significantly different. 
All three of these previous models are subject to some extreme data limitations. First, Barzel's theory was originally formulated in terms of the quality of the product, not the price, which is used as the basis for testing his hypothesis in each of the models discussed above. This indirect test using price requires an additional assumption that the full amount of the tax is passed on to the consumer. If this is not the case, then the coefficient on the TAX variable could be less than one but still consistent with Barzel's hypothesis. For example, if only half the tax is passed on to the consumer, then a coefficient less than 1.0 , but still greater than 0.5 , would suggest a quality improvement consistent with Barzel's model. As a result, Sumner and Ward's finding that the tax coefficient was significantly less than one could be a rejection of the assumption that the full amount of the tax is passed on to consumers, and not a rejection of Barzel's theory. Sumner and Ward even point to some reasons why the price should not rise by the full amount of the tax, such as the ability of consumers to do cross-border shopping.

The second, and more important, limitation of these earlier models is that they all estimate the quality improvement from a specific state's tax rate change in terms of a change in the price of cigarettes in that state. Because the empirical model is cross sectional, empirical confirmation of Barzel's theory requires that the quality of cigarettes in a specific state can vary with the unit taxes imposed in that state independent of the quality of cigarettes in all other states. Sumner and Ward cite this as a major limitation to Barzel's and Johnson's empirical studies. Even Barzel points to the limited ability of cigarette quality to differ across states in response to differing unit taxes. ${ }^{19}$ If there are conditions in the cigarette market that constrain quality from differing across states, then

\footnotetext{
${ }^{19}$ Barzel mentions that some within state changes in consumer choices of quality levels could be toward higher-priced $100 \mathrm{~mm}$ cigarettes and those from vending machines.
} 
one might expect a coefficient near one, as a change in a single state's unit tax on cigarettes should result in only a small impact on the overall quality level of cigarettes in the U.S. as a whole.

Improving upon the indirect method used in the three studies discussed above, Sobel and Garrett (1997) conduct the first direct test of Barzel's theory using data that directly measures product quality. Lower quality, generic-brand cigarettes began acquiring a sizable share of the cigarette market in 1982. Generic-brand cigarettes are of a lower quality level relative to premium-brands on many margins, including taste, quality of tobacco, and freshness. The arrival of generic-brand cigarettes permitted the development of a better empirical model than had been previously estimated. In their model, Sobel and Garrett look at the market share of the higher-quality, premium-brand cigarettes relative to the market share of lower-quality, generic-brand cigarettes to directly measure the impact of state taxes on the average quality of cigarettes consumed in a state. Because state unit taxes on cigarettes are the same for both generic and premium brands, Barzel's theory predicts that the unit tax should cause consumers to substitute out of generic- and into premium-brand cigarettes. His theory also predicts that general ad valorem retail sales taxes, which have no impact the relative prices of genericand premium-brand cigarettes, do not cause a change in the market share of premium brand cigarettes.

Sobel and Garrett's test is much stronger and more direct than the previous tests done using only price data. Additionally, testing Barzel's hypothesis using price data is subject to many limitations, such as the assumption about how much of the tax burden falls on consumers. Their model can be expressed as follows: 
$\%$ PREMIUM $_{i t}=\alpha_{0}+\alpha_{1}$ UNITTAX $_{i t}+\alpha_{2}$ SALESTAX $_{i t}+$ year dummies + state dummies $+\varepsilon_{i t}$

where $\% \mathrm{PREMIUM}_{\mathrm{it}}$ is the market share of premium brand cigarettes in state $i$ and year $t$, UNITTAX $_{\text {it }}$ is the per unit state tax on cigarettes in state $i$ and year $t$, SALESTAX it is the ad valorem sales tax rate applicable on cigarette sales in state $i$ and year $t$, and also included in the regression are a set of year dummy variables and a set of state dummy variables. Their model was estimated using data from 1990-1994. Barzel's theory predicts that the coefficient on UNITTAX is positive and significant, while the coefficient on SALESTAX is zero.

Sobel and Garrett interpret their results as supportive of Barzel's theory. The authors find that the market share of premium-brand cigarettes is significantly larger in states with larger unit taxes on cigarettes than it is in low-tax states. Their estimates suggest that for every three cents of a state unit tax, the market share of premium-brand cigarettes increases by about one percentage point. The ad valorem sales tax is found to be insignificant in determining the market share of premium-brand cigarettes. Furthermore, New Hampshire's cigarette specific ad valorem tax, which was the only ad valorem excise tax on cigarettes at the time of their study, is found to be an insignificant determinant of product quality. Their results are also reproduced in Table 3.1.

Based on the empirical work examining Barzel's theory as applied to the cigarette market, it is difficult to draw concrete inferences about the validity of his theory. The early tests of Barzel's theory, using a formulation based on changes in product price, produced mixed results. Sobel and Garrett (1997), through the availability of improved data, were able to use a direct method to find empirical evidence of Barzel's theory in the 
market for cigarettes. Yet, it remains unclear whether Barzel's theory can be applied generally to all cases of unit and ad valorem taxation, or whether the theory describes behavior that is unique to the cigarette market. This question is of concern, particularly given that Barzel, himself, was unable to find supporting evidence of his theory in any market other than cigarettes. This chapter now turns to a reevaluation of the market for gasoline, one of the markets in which Barzel could not find empirical support of his theory.

\subsection{Empirical Test of the Market for Gasoline}

Much of the existing literature studying gasoline markets focuses on estimating the demand and price elasticity of demand for gasoline, where quantity serves as the dependent variable. ${ }^{20}$ This chapter alternatively estimates the market shares of the three quality grades of gasoline (regular, mid-grade, and premium). Because only the relative quantities of these quality grades are of importance, I avoid many of the complications associated with estimating demand directly. ${ }^{21}$ In addition, the use of market share data allows for the average quality of gasoline to vary independently across states, addressing an issue that Sumner and Ward (1981) cite as a major limitation of earlier tests using the indirect approach to testing Barzel's theory.

The effects of gasoline taxation on the quality of gasoline consumed, as measured by changes in the market shares of each grade of gasoline (regular, mid-grade, and

\footnotetext{
${ }^{20}$ Archibald and Gillingham (1980) and, Kayser (2000) estimate gasoline demand using household-level data with the latter finding a price elasticity of -0.23 .

${ }^{21}$ There is also a strand of literature examining the long-run adjustment, namely the choice of fuel type (gasoline, diesel, and LPG), in response to tax policy changes, such as Rouwendal and de Vries (1999). These studies are different from the current study in that they reflect long-run adjustments rather than short-run adjustments to a change in tax policy.
} 
premium), is estimated following the method introduced by Sobel and Garrett (1997). ${ }^{22}$ Annually averaged state-level daily volume sales (retail plus wholesale) by grade of gasoline for 1991-2001 are obtained from the Energy Information Administration. Data on gasoline taxes were collected from Highway Statistics while per capita income was obtained from the Census Bureau. Descriptive statistics of the data used in this study can be found in Table 3.2. The year 1991 is chosen as the first observation year to avoid any interactions between leaded and unleaded gasoline. ${ }^{23}$ All states levy a per-gallon tax on gasoline and seven states apply their ad valorem sales tax to gasoline sales during the sample period. $^{24}$

Table 3.2

Descriptive Statistics, 1991-2001

\begin{tabular}{|l|r|r|r|r|}
\hline \multicolumn{1}{|c|}{ Variable } & \multicolumn{1}{c|}{ Mean } & \multicolumn{1}{c|}{ Std.Dev. } & Minimum & Maximum \\
\hline Market Share--Regular & 72.177 & 10.284 & 30.779 & 93.376 \\
Market Share--Mid-grade & 10.469 & 4.471 & 0.056 & 22.261 \\
Market Share--Premium & 17.025 & 6.878 & 4.305 & 48.494 \\
\hline & & & & \\
Unit Tax & 44.608 & 7.012 & 25.263 & 70.934 \\
Sales Tax & 0.725 & 1.797 & 0.000 & 6.250 \\
Per Capita Income (\$1,000) & 27.378 & 4.526 & 17.816 & 44.731 \\
Percent Male Drivers & 50.304 & 1.341 & 46.050 & 55.431 \\
Percent Drivers under Age 35 & 34.916 & 3.137 & 23.967 & 44.756 \\
Percent Drivers over Age 54 & 25.539 & 2.753 & 14.481 & 32.728 \\
\hline
\end{tabular}

${ }^{22}$ Barzel's theory also suggests that the octane rating for all grades of gasoline may rise in response to unit taxation. I am indebted to Barzel for this insight. Data limitations prevent the testing of this effect here.

${ }^{23}$ Prior to 1991 both leaded gasoline and unleaded gasoline were sold at retail stations, whereas only unleaded gasoline has been sold at retail stations since 1991. All observations from North Dakota, South Dakota, and Wyoming were excluded from the sample due to data limitations.

${ }^{24}$ These seven states are CA, GA, HA, IN, IL, MI, and NY. 
A state-fixed effects model is estimated for each grade of gasoline. ${ }^{25}$ The market share for each grade of gasoline is estimated as a function of the unit tax amount, the ad valorem (sales) tax rate, and a set of control variables $(\Gamma)$. The empirical model can be written:

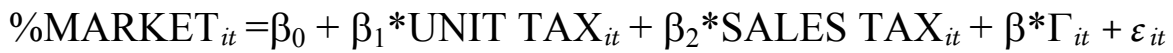

where $\% \mathrm{MARKET}_{i t}$ is the market share of the specified grade of gasoline (regular, midgrade, or premium), UNIT TAX $_{i t}$ is the sum of the federal and state tax on gasoline in cents per gallon, SALES TAX Tit $_{i}$ is the sales tax rate applied to gasoline, and $\Gamma$ is a matrix of other control variables, where $i$ and $t$ represent state and time, respectively. In specification [1], $\Gamma$ includes the constant, a time trend, and a FTC dummy variable (explained below). Specification [2] differs from specification [1] by only a set of variables add to $\Gamma$ to control for driver characteristics: per capita income, percent male licensed drivers, and percent licensed drivers in various age groups.

The FTC dummy variable is included in all specifications of the model to estimate the impact of education campaigns resulting from the 1997 settlement between the Federal Trade Commission (FTC) and Exxon. In 1996 the FTC charged Exxon with making exorbitant advertising claims concerning the ability of Exxon 93 Supreme to clean engines and reduce automobile maintenance costs. Exxon agreed to replace their previous advertisements with educational advertising concerning the choice of gasoline grades. The primary message of the new advertising was that premium gasoline does not

\footnotetext{
${ }^{25}$ The Hausman test was conducted with the results supporting the random-effects specification. The seemingly unrelated regression (SUR) model is generally more efficient that ordinary least squares (OLS) since my dependent variables (market shares) are correlated. However, since all right-hand-side variables are identical, there are no efficiency gains to using SUR. Thus, single-equation OLS is the efficient estimator.
} 
significantly improve engine performance. If the FTC's efforts were effective, there should be a significant decline in the market share of premium gasoline starting in 1997, which needs to be controlled for in the analysis.

According to Barzel, the coefficient on UNIT $\mathrm{TAX}_{i t}$ should be positive and significant in the \%PREMIUM model and negative and significant in the \%REGULAR model. The sign of this coefficient in the \%MIDGRADE model is less clear. However, it is reasonable to expect it to be positive because of the sheer size differential between the two markets. The market share for regular gasoline is nearly seven times that of midgrade gasoline during the period studied. Thus, the potential for consumers to substitute from regular to mid-grade is much larger than the potential for consumers to substitute from mid-grade to premium. The coefficient on SALES TAX it $_{\text {should be insignificant }}$ from zero for all three grades because the tax induces no change in relative prices. The results from both specifications using market share data for all grades all gasoline are provided in Table 3.3.

While the results are robust to different specifications, I discuss those from the specification with the added variables to control for driver characteristics, namely specification [2]. The coefficient on UNIT $\mathrm{TAX}_{i t}$ is significant at the one percent level and is of the predicted sign in both specifications involving regular gasoline and premium gasoline. These estimates imply that a one cent increase in the unit tax, either at the state or federal level, causes a 0.21 percentage point increase in the market share of premium gasoline while causing the market share of regular gasoline to fall by about 0.22 percentage points. Interestingly, the coefficient on UNIT $\mathrm{TAX}_{i t}$ in the mid-grade gasoline case is always positive and significant at the one percent level in both 
Table 3.3

State-Fixed Effects Models ${ }^{1}$

1991-2001

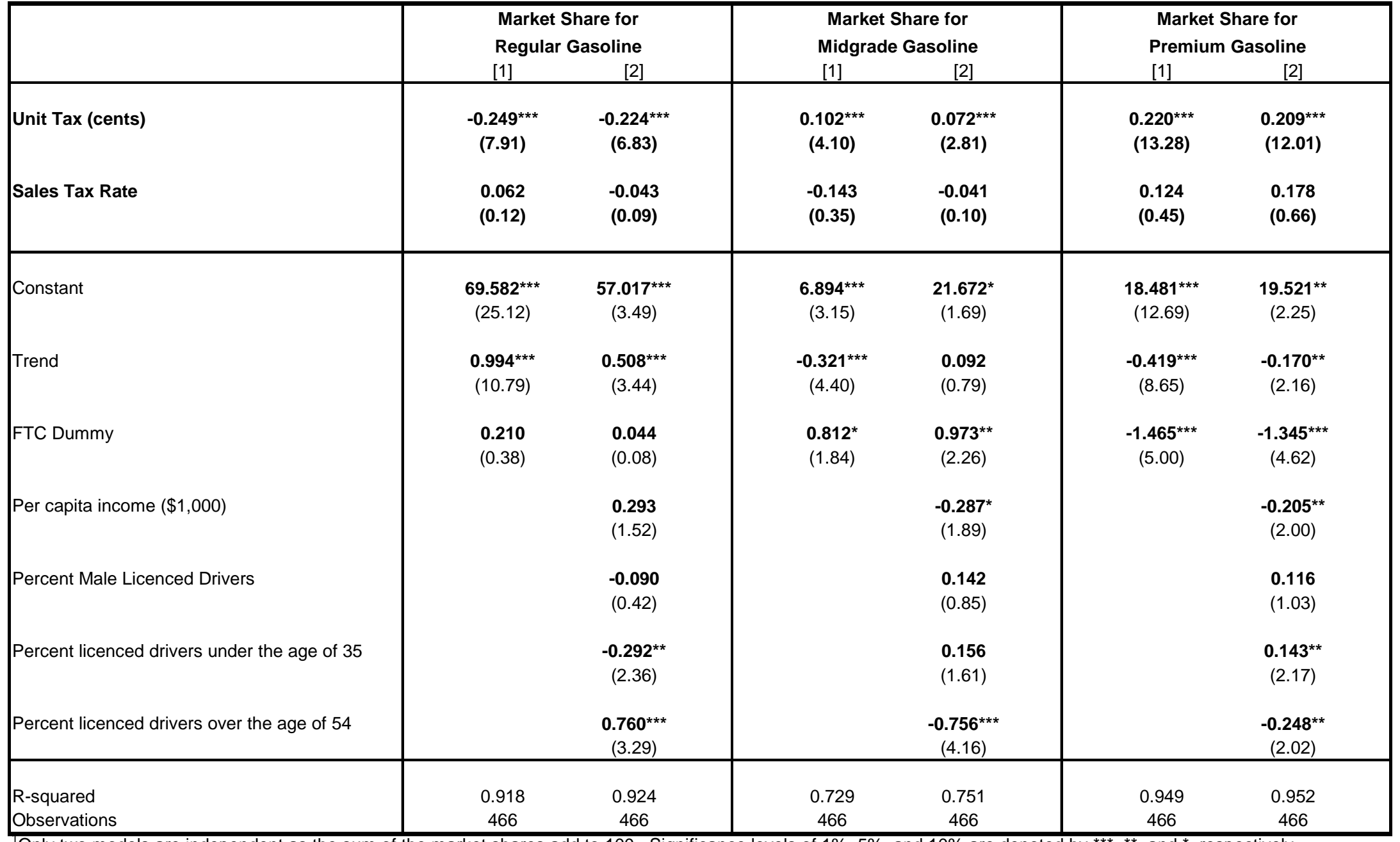

IOnly two models are independent as the sum of the market shares add to 100 . Significance levels of $1 \%, 5 \%$, and $10 \%$ are denoted by ${ }^{* * *}$, ${ }^{* *}$, and ${ }^{*}$, respectively.

Absolute t-ratios appear in parenthesis. Regressions also include state dummy variables, which are not reported in the table. 
specifications, suggesting greater consumer inflow from regular gasoline than outflow to premium gasoline. The estimates imply that a one cent increase in the unit tax on gasoline causes the market share of mid-grade gasoline to rise by about 0.07 percentage

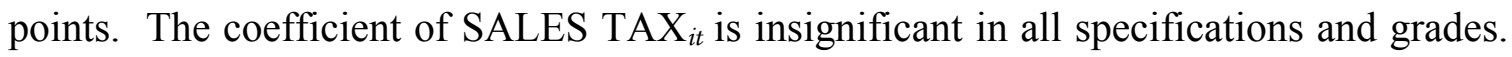
Thus, the imposition of an ad valorem tax exerts no significant effect on consumers' purchases of gasoline grade.

The results suggest that the educational advertisements mandated by the FTC to educate consumers of the limited benefits of using high-octane fuel were effective in reducing the use of premium gasoline relative to the other two quality grades. The market share of premium gas fell by 1.35 percentage points in response to these campaigns. The impact of these advertisements should be interpreted as economically significant because the mean market share of premium gasoline is only about $17 \%$ over the sample period.

\subsection{Conclusion}

Although Barzel's theory has become accepted as a standard idea in tax theory, supporting empirical evidence has been somewhat scarce. The early literature employed a model biased against the theory and failed to find empirical support for the theory in markets other than cigarettes. Although Sobel and Garrett (1997) use an unbiased empirical model to find evidence in support of Barzel's theory, one may still question whether the theory is general to all markets or whether this result is unique to the cigarette market. 
This chapter tests and confirms Barzel's theory in the gasoline market, a market in which Barzel himself was unable to find supporting evidence in his original article. The results presented here suggest that per-unit gasoline taxes lead to proportionately more consumption of higher-quality, premium gasoline and proportionately less of lowerquality, regular gasoline. For every five cents of combined state and federal unit tax on gasoline, it is shown that the market share of premium gasoline increases by approximately one percentage point, while the market share of regular gasoline falls by approximately the same amount. Given that the combined state and federal unit tax for the average state was 44.608 cents per gallon in the year 2001, these results suggest that the market share for premium gasoline is about 9.3 percentage points greater than it otherwise would have been without the tax. The market share for regular gasoline in the average state is approximately 10.0 percentage points smaller due to unit taxation. Ad valorem taxes are shown to have no effect on the relative purchase of gasoline grades.

This chapter is the first to confirm the implications of Barzel's theory in a market other than the cigarette market, suggesting that his theory is not unique to the cigarette market, but can be applied more generally to all cases of unit taxation. While the results presented here appear to provide strong evidence in support of Barzel's theory, the empirical model used is subject to two major criticisms. First, the model does not control for the impact that cross-border sales may exert the purchase of product quality. The Alchian and Allen theorem suggests that cross-border shoppers, who have incurred a larger fixed unit cost of travel, should purchase higher levels of quality. Ignoring the cross-border effect may bias the estimate of the impact that unit taxation has on the purchase of product quality. 
The purchase of product quality may also depend on the geographic region in which the consumption takes place, introducing a spatial component to the analysis. Preference for gasoline grade is likely to change gradually over space. Thus, if the consumption of premium gasoline is high in one state, it is also likely to be high in the neighboring states. When spatial dependence is present but not controlled for in the empirical model, the estimates may be biased and inconsistent or inefficient. The analysis of Chapter 4 addresses the short-comings of the model presented in this chapter by controlling for spatial dependence and by adding a variable to capture the cross-border sales effect. 


\section{Chapter 4 \\ Cross-Border Shopping and Product Quality: The Gasoline Market}

\subsection{Introduction}

This chapter builds on the analysis of the previous chapter by controlling for spatial dependence and by adding a cross-border sales variable to the empirical model. The empirical results of Chapter 3 offer support for Barzel's theory, which states that average product quality should rise in response to higher levels of per-unit taxation. While Barzel's theory is specific to the per-unit excise tax, this quality substitution can be explained more generally by the Alchian and Allen theorem. The Alchian and Allen theorem explains that the imposition of a fixed unit charge on the purchase of a good causes a decrease in the relative price of the higher-quality version of the good. The lower relative price will lead some consumers to substitute toward higher quality. Thus, a per-unit tax, which imposes a fixed charge on each unit of a good regardless of its quality level, should cause some consumers to purchase higher levels of quality.

In a federal economy such as the United States, where excise taxes can vary widely from one state to the next, the Alchian and Allen theory implies that the average quality level of a good subject to an excise tax should be greater in high tax states. Recent empirical evidence supports this implication. Sobel and Garrett (1997) show that the market share of premium-brand cigarettes is greater in states with higher unit taxes on cigarettes. ${ }^{26}$ Similarly, the analysis of the previous chapter of this dissertation suggests

\footnotetext{
${ }^{26}$ See Barzel (1976), Johnson (1978), and Sumner and Ward (1981) for further studies of quality substitution in the cigarette market.
} 
that the market shares of mid-grade and premium-grade gasoline are greater in high unit tax states.

In addition to the relative-price effect described above, per unit taxes can also generate a secondary effect on product quality through cross-border shopping. Crossborder shopping occurs when product prices differ substantially across political boundaries, such as state-lines. While interstate price differentials can exist for several reasons, they are often the result of differences in state tax policies. Therefore, when taxes are sufficiently lower in a nearby region, some consumers are willing to incur the additional travel costs to take advantage of lower product prices. These travel costs can be viewed as a fixed unit cost; that is, regardless of what is purchased during the trip the consumer bears a fixed cost of travel. Thus, the Alchian and Allen theorem implies that average product quality consumed should be higher in states with greater net cross-border sales. Since lower tax rates relative to those of the surrounding states are often needed to attract cross-border sales, this suggests that product quality may increase with decreases in home tax rates.

An increase in the unit tax rate in a particular state, then, has two conflicting effects on product quality according to the Alchian and Allen theorem. The relative-price effect suggests that a larger unit tax in the state leads to increased product quality. The cross-border effect suggests that lower unit tax rates in a state relative to the bordering states causes an increase in product quality. The net effect of an increase in a state's unit tax on average product quality depends on the relative elasticities of in-state demand and cross-border demand for product quality. Determining whether product quality increases or decreases in response to changes in unit tax rates is an empirical matter. 
The goal of this chapter is to answer this question for the gasoline market. To do so, a two-way fixed-effects model corrected for spatial autocorrelation is employed using annual data on state-level market shares for premium-grade and regular-grade gasoline. Table 4.1 reports the state tax rates applicable to gasoline as of January 1, 2005. There is wide variation in the tax rates applicable to gasoline across the states. The per unit tax rate ranges from a low of seven and a half cents per gallon in Georgia to a high of thirtyone cents per gallon in Rhode Island. In addition to the unit tax on gasoline, seven states apply the state sales tax rate to purchases of gasoline, which may cause some residents of these states to shop for gasoline across the border. ${ }^{27}$

The chapter proceeds as follows: Section 4.2 reviews the relevant literature on cross-border shopping and quality substitution. Section 4.3 develops the empirical model and presents the results. Finally, concluding remarks and policy implications are offered in Section 4.4.

\subsection{Literature Review}

\subsubsection{Cross-Border Shopping}

Before discussing the issue of quality substitution, it is worth while to first discuss the literature related to cross-border shopping. Cross-border shopping is a casual form of smuggling goods across political boundaries. The more organized form of smuggling, known as commercial smuggling or bootlegging, involves (1) the purchase of a good in low-tax states or in illegal markets where no taxes are paid and (2) the resale of the good in high-tax states through illegal markets. While there is evidence that this form of smuggling may be important in some markets, cross-border shopping is the primary focus

\footnotetext{
${ }^{27}$ These seven states are CA, GA, HI, IL, IN, MI, and NY.
} 
Table 4.1

State Tax Rates Applicable To Gasoline Sales as of January 1, 2005

Sorted Alphabetically by State Name

\begin{tabular}{|c|c|c|}
\hline State & $\begin{array}{c}\text { Unit } \\
\text { (cents/gallon) }\end{array}$ & Sales (\%) \\
\hline Alabama & 18.00 & --- \\
\hline Alaska & 8.00 & --- \\
\hline Arizona & 18.00 & --- \\
\hline Arkansas & 21.50 & --- \\
\hline California & 18.00 & 6.00 \\
\hline Colorado & 22.00 & --- \\
\hline Connecticut & 25.00 & --- \\
\hline Delaware & 23.00 & --- \\
\hline District of Columbia & 22.50 & --- \\
\hline Florida & 14.50 & --- \\
\hline Georgia & 7.50 & 4.00 \\
\hline Hawaii & 16.00 & 4.00 \\
\hline Idaho & 25.00 & --- \\
\hline Illinois & 20.10 & 6.25 \\
\hline Indiana & 18.00 & 6.00 \\
\hline lowa & 20.50 & --- \\
\hline Kansas & 24.00 & --- \\
\hline Kentucky & 17.40 & --- \\
\hline Louisiana & 20.00 & --- \\
\hline Maine & 25.20 & --- \\
\hline Maryland & 23.50 & --- \\
\hline Massachusetts & 21.00 & --- \\
\hline Michigan & 19.00 & 6.00 \\
\hline Minnesota & 20.00 & --- \\
\hline Mississippi & 18.40 & --- \\
\hline Missouri & 17.03 & --- \\
\hline Montana & 27.00 & --- \\
\hline Nebraska & 26.30 & --- \\
\hline Nevada & 23.00 & --- \\
\hline New Hampshire & 19.50 & --- \\
\hline New Jersey & 14.50 & --- \\
\hline New Mexico & 18.90 & --- \\
\hline New York & 23.20 & 4.25 \\
\hline North Carolina & 26.85 & --- \\
\hline North Dakota & 21.00 & --- \\
\hline Ohio & 26.00 & --- \\
\hline Oklahoma & 17.00 & --- \\
\hline Oregon & 24.00 & --- \\
\hline Pennsylvania & 30.00 & --- \\
\hline Rhode Island & 31.00 & --- \\
\hline South Carolina & 16.00 & --- \\
\hline South Dakota & 22.00 & --- \\
\hline Tennessee & 21.40 & --- \\
\hline Texas & 20.00 & --- \\
\hline Utah & 24.50 & --- \\
\hline Vermont & 20.00 & --- \\
\hline Virginia & 17.50 & --- \\
\hline Washington & 28.00 & --- \\
\hline West Virginia & 27.00 & --- \\
\hline Wisconsin & 29.10 & --- \\
\hline Wyoming & 14.00 & --- \\
\hline
\end{tabular}

Source: Federation of Tax Administrators
Sorted by Unit Tax Rate

\begin{tabular}{|c|c|c|}
\hline State & $\begin{array}{c}\text { Unit } \\
\text { (cents/gallon) }\end{array}$ & Sales (\%) \\
\hline Rhode Island & 31.00 & --- \\
\hline Pennsylvania & 30.00 & --- \\
\hline Wisconsin & 29.10 & --- \\
\hline Washington & 28.00 & --- \\
\hline Montana & 27.00 & --- \\
\hline West Virginia & 27.00 & --- \\
\hline North Carolina & 26.85 & --- \\
\hline Nebraska & 26.30 & --- \\
\hline Ohio & 26.00 & --- \\
\hline Maine & 25.20 & --- \\
\hline Connecticut & 25.00 & --- \\
\hline Idaho & 25.00 & --- \\
\hline Utah & 24.50 & --- \\
\hline Kansas & 24.00 & --- \\
\hline Oregon & 24.00 & --- \\
\hline Maryland & 23.50 & --- \\
\hline New York & 23.20 & 4.25 \\
\hline Delaware & 23.00 & --- \\
\hline Nevada & 23.00 & --- \\
\hline District of Columbia & 22.50 & --- \\
\hline Colorado & 22.00 & --- \\
\hline South Dakota & 22.00 & --- \\
\hline Arkansas & 21.50 & --- \\
\hline Tennessee & 21.40 & --- \\
\hline Massachusetts & 21.00 & --- \\
\hline North Dakota & 21.00 & --- \\
\hline lowa & 20.50 & --- \\
\hline Illinois & 20.10 & 6.25 \\
\hline Louisiana & 20.00 & --- \\
\hline Minnesota & 20.00 & --- \\
\hline Texas & 20.00 & --- \\
\hline Vermont & 20.00 & --- \\
\hline New Hampshire & 19.50 & --- \\
\hline Michigan & 19.00 & 6.00 \\
\hline New Mexico & 18.90 & --- \\
\hline Mississippi & 18.40 & --- \\
\hline Alabama & 18.00 & --- \\
\hline Arizona & 18.00 & --- \\
\hline California & 18.00 & 6.00 \\
\hline Indiana & 18.00 & 6.00 \\
\hline Virginia & 17.50 & --- \\
\hline Kentucky & 17.40 & --- \\
\hline Missouri & 17.03 & --- \\
\hline Oklahoma & 17.00 & --- \\
\hline Hawaii & 16.00 & 4.00 \\
\hline South Carolina & 16.00 & --- \\
\hline Florida & 14.50 & --- \\
\hline New Jersey & 14.50 & --- \\
\hline Wyoming & 14.00 & --- \\
\hline Alaska & 8.00 & --- \\
\hline Georgia & 7.50 & 4.00 \\
\hline
\end{tabular}


of this paper. ${ }^{28}$ Cross-border shopping occurs when residents of a given jurisdiction travel across a political boundary to take advantage of lower prices outside the home jurisdiction. Large price differentials across jurisdictions are often driven by interstate tax differentials.

There are numerous theoretical models of cross-border shopping and the resulting tax competition between political jurisdictions. Several of these studies have shown that direct tax competition causes the regions to reduce their tax rates below the socially efficient levels, leading to a general underprovision of public goods. Kanbur and Keen (1993), Wang (1999), and Neilson (2001) each assume an evenly distributed population, modeling interstate tax competition as a Nash game under various assumptions. Trandel (1994) and Ohsawa (1999) allow for asymmetric populations and densities between the competing jurisdictions. Lucus (2004) considers a federal economy allowing for both horizontal and vertical externalities.

While much of the theoretical literature has focused on tax competition among political jurisdictions, most of the empirical studies of cross-border shopping have taken tax rates as given and focused on estimating the impacts of those taxes on regional sales. ${ }^{29}$ Mikesell and Zorn (1986) and Mikesell (1971) find some evidence that sales tax differentials can encourage cross-border sales and that department store sales are impacted more than convenience goods stores. Coats (1995) and Saba et al. (1995) both find evidence of cross-border shopping in response to cigarette taxation. According to Coats' results, about eighty percent of the sales response to changes in the cigarette

\footnotetext{
${ }^{28}$ See Thursby et al. (1991) and Thursby and Thursby (2000) for detailed analysis of commercial smuggling.

${ }^{29}$ One exception is Nelson (2002), who presents an empirical analysis examining how states determine their commodity tax rates.
} 
excise tax is due to cross-border shopping. Beard et al. (1997), applying the microanalytic model of Saba et al (1995) to the market for alcohol, suggest that crossborder shopping is a significant determinant of alcohol sales in some regions. Additional evidence of cross-border shopping in response to differences in the tax treatment of wine and liquor across states is presented in Chapter 2 of this dissertation.

In a related issue, Garrett and Marsh (2002) use county-level data from Kansas and find strong evidence of cross-border lottery shopping. While cross-border lottery shopping is not driven by interstate tax differentials per se, a primary force behind these sales is the differences in state take-out rates, which can be viewed as an implicit tax on the winnings. Garrett and Marsh also find evidence of spatial autocorrelation in their lottery sales data, suggesting that lottery sales in a county is influenced by the lottery sales in nearby counties. The spatial autocorrelation problem is also an issue that must be dealt with in the empirical analysis of this chapter, as will be discussed further in Section 4.3 .

The previous literature clearly suggests that the occurrence of cross-border shopping can play a significant role in determining a state's overall sales volume in at least some markets. However, this literature has developed no inferences on the purchases of quality when cross-border shopping is prevalent. Before addressing the issue of how cross-border shopping, induced by interstate tax differentials, impacts product quality, the chapter first provides a general overview concerning the literature on quality substitution. 


\subsubsection{Unit Costs and Product Quality}

Alchian and Allen (1967) theorized that the imposition of a fixed charge, such as a transportation cost, causes the price of the higher-quality version of a good to fall relative to a lower-quality substitute. Given that the price of the higher-quality good is relatively cheaper, consumers in the aggregate tend to purchase proportionately more of it. The Alchian and Allen theorem is often referred to as the "third law of demand" because of its ability to predict consumer behavior. The third law of demand was originally modeled in a two-good world with few additional assumptions. Borcherding and Silberberg (1978) extend the model to a three-good world (two quality-grades of one product plus another good), showing that the imposition of a transportation cost does increase the consumption of the higher-quality good relative to a lower-quality substitute under certain conditions. Razzolini, Shughart, and Tollison (2003) compare the results of a perfectly competitive market to those of a monopoly market. While a fixed charge unambiguously reduces the relative price of the higher-quality good in a perfectly competitive market, the outcome is ambiguous in a monopoly market, depending on the elasticities of demand and supply. ${ }^{30}$

Examples of the Alchian and Allen theorem are abundant. Borcherding and Silberberg (1978) discuss a letter appearing in the Seattle Times written by a Washington resident complaining that all the apples for sale in the state of Washington are "small and old-looking." She asks why such an outcome is reached. Silberberg's answer, also appearing in the Seattle Times, to why so few high-quality apples are for sale in a state known for its apple orchards is that good apples are relatively cheaper in the East than they are in the West due to transportation costs, consistent with Alchian and Allen

\footnotetext{
${ }^{30}$ See Leffler (1982), Umbeck (1980) and Cowen and Tabarrok (1995) for on the theoretical modeling of the third law of demand.
} 
theorem. Other common observations that can be explained by the third law of demand include vacationers enjoying a higher-quality vacation the further they travel and couples who hire a babysitter for the evening choosing to attend the theater rather than the cinema. Bertonazzi, Maloney, and McCormick (1993) apply the theory to the purchase of Clemson University football tickets, showing that individuals who travel longer distances to attend the football games tend to purchase better seats than do other attendees.

The third law of demand also applies to cases of unit taxation. A unit tax is just like any other fixed fee, and therefore should reduce the relative price of the higherquality good. Barzel (1976) offers a complimentary explanation to the Alchian and Allen theorem for the case of unit taxation. He explains that per unit excise taxes do not tax all attributes of a good, leaving the quality attributes untaxed. Consumers substitute away from the taxed attribute (which is quantity) and into the untaxed attribute (which is quality). Ad valorem taxes, which are based on the price of the good, do tax all attributes of the good and induce no quality substitution. Johnson (1978) and Sobel and Garrett (1997) offer support for the theory in the cigarette market while the results of Chapter 3 of this dissertation show support of the theory in the market for gasoline. ${ }^{31}$

\subsection{Empirical Model and Results}

Based on the empirical literature discussed above, the imposition of a unit tax on a particular commodity induces consumers to substitute toward higher-quality in at least some markets. These studies test for quality substitution effects through the impact on

\footnotetext{
${ }^{31}$ Sumner and Ward (1982) empirically reject the theory in the cigarette market. Barzel and Hall (1977) also find evidence of quality substitution due to oil import quotas.
} 
relative prices. However, state tax rates vary widely, and the resulting interstate tax differentials have been shown to cause cross-border shopping. Cross-border shoppers must generally travel further distances than the typical in-state shopper, imposing a fixed cost per trip on cross-border shoppers. Just as travel distance influences the purchase of Clemson football tickets in Bertonazzi, Maloney, and McCormick (1993), it should increase average product quality in the case of cross-border sales. Thus, an increase in a state's per-unit excise tax impacts product quality in two ways: First, the relative price of the higher-quality version falls, causing consumers to substitute toward higher quality. Second, the state will observe a decline in net cross-border sales, as the higher tax drives away some cross-border shoppers, who happen to be more likely to purchase higherquality goods according to the third law of demand. These two effects will be tested using gasoline market data.

The empirical model used in this study is based on the model introduced by Sobel and Garrett (1997). Like the market for cigarettes, which is characterized by two distinct quality grades - premium-brand and generic-brand cigarettes - the gasoline market allows for the direct measurement of changes in product quality. Consumers can choose between three quality-grades of gasoline (regular-grade, mid-grade, and premium-grade), where quality is defined by octane level. In order to directly measure how product quality varies in response to changes in state tax policy, the market shares for regulargrade and premium-grade gasoline are used. For example, an increase in product quality can be measured by an increase in the market share of premium-grade gasoline.

Annually averaged daily volume sales data by gasoline grade and by state for the time period 1994-2001 was obtained from the Energy Information Administration (EIA). 
From this, the market shares of regular-grade and premium-grade gasoline were calculated. $^{32}$ Data on gasoline taxes, percent male licensed drivers, and the percent of licensed drivers in various age groups were collected from Highway Statistics while per capita income was obtained from the Census Bureau. In order to measure the effect of cross-border sales, a measure of the interstate tax differential must be constructed. As such, the average unit tax rate differential between the home state and bordering states is calculated for every state. The year 1994 is chosen as the first year of observation because it is the earliest year in which all necessary variables were available to ensure a balanced panel. ${ }^{33}$ Descriptive statistics of the data used in this study can be found in Table 4.2.

Table 4.2

Descriptive Statistics, 1994-2001

\begin{tabular}{|l|r|r|r|r|}
\hline \multicolumn{1}{|c|}{ Variable } & \multicolumn{1}{|c|}{ Mean } & \multicolumn{1}{c|}{ Std.Dev. } & \multicolumn{1}{c|}{ Minimum } & Maximum \\
\hline Market Share--Regular & 73.990 & 8.199 & 53.666 & 93.376 \\
Market Share--Premium & 15.824 & 5.157 & 4.305 & 32.803 \\
\hline & & & & \\
Unit Tax & 45.570 & 7.102 & 25.683 & 70.934 \\
Average Unit Tax Differential & 0.084 & 4.690 & -19.331 & 15.262 \\
Sales Tax & 0.677 & 1.782 & 0.000 & 6.250 \\
Per Capita Income (\$1,000) & 27.381 & 4.292 & 19.468 & 42.919 \\
Percent Male Drivers & 50.058 & 1.131 & 46.050 & 53.810 \\
Percent Drivers under Age 35 & 34.206 & 2.952 & 23.967 & 44.522 \\
Percent Drivers over Age 54 & 25.993 & 2.407 & 18.767 & 32.728 \\
\hline
\end{tabular}

The market share for both grades of gasoline is modeled as a function of the unit tax amount (in cents), the average unit tax rate differential (in cents), the ad valorem sales

\footnotetext{
${ }^{32}$ Results for mid-grade gasoline can be inferred from the results of regular-grade and premium-grade gasoline because the sum of the market shares must equal one hundred percent.

${ }^{33} \mathrm{ND}$, SD, and WY are excluded due to missing observations. AK and HI are excluded because neither state borders another state in the union.
} 
tax rate (in percent), and a set of variables, $\Gamma$, to control for driver characteristics in each state. The variables included in $\Gamma$ are per capita income, percent licensed drivers who are male, percent licensed drivers under the age of thirty-five, and the percent licensed drivers over the age of sixty-four. The empirical model can be written:

$$
\begin{gathered}
\% \text { MARKET }_{i t}=\beta_{0}+\beta_{1} * \operatorname{UNIT~TAX~}_{i t}+\beta_{2} * \text { TAX DIFFERENTIAL }_{i t}+ \\
\beta_{3} * \operatorname{SALES~TAX~}_{i t}+\beta^{*} \Gamma_{i t}+\varepsilon_{i t}
\end{gathered}
$$

where $\% \mathrm{MARKET}_{i t}$ is the market share of the specified grade of gasoline (regular or premium), UNIT $\mathrm{TAX}_{i t}$ is the sum of the federal and state tax on gasoline in cents per gallon, TAX DIFFERENTIAL ${ }_{i t}$ is the average difference between state $i$ 's unit tax on gasoline and the unit tax in each of the bordering states in cents per gallon, SALES TAX $X_{i t}$ is the sales tax rate applied to gasoline, and $\Gamma$ is a matrix of other control variables, where $i$ and $t$ represent state and time, respectively.

The relative-price effect of the gasoline unit tax on product quality can be

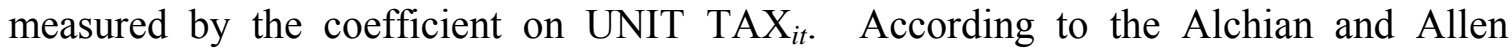
theorem, an increase in the unit tax (a fixed charge) reduces the relative price of premium-grade gasoline, leading some consumers to substitute toward higher-quality, premium-grade gasoline. Thus, the coefficient on UNIT $\mathrm{TAX}_{i t}$ is predicted to be positive and significant in the \%PREMIUM model and negative and significant in the \%REGULAR model. The coefficient on SALES TAX $\mathrm{X}_{\mathrm{it}}$ is hypothesized to be insignificant in both models because the tax induces no change in relative prices. 
The cross-border effect of the gasoline unit tax on product quality is picked up by the coefficient on the TAX DIFFERENTIAL ${ }_{i t}$ variable. This variable is calculated as the average of the home tax rate minus the tax rate of each bordering state. Thus, a negative value signifies that state $i$ has, on average, a lower unit tax on gasoline relative to the rate in the bordering states. A state is expected to experience a large net gain in cross-border sales of gasoline when the TAX DIFFERENTIAL ${ }_{i t}$ variable is negative and large in magnitude. Cross-border shoppers are assumed to have traveled farther than in-state consumers. Thus, according to the third law of demand, they will be more likely to purchase higher octane gasoline than the typical in-state consumer. This is because the larger fixed unit cost of travel for cross-border shoppers reduces the relative price of premium-grade gasoline. Therefore, a state with a lower unit tax on gasoline relative to its bordering states, all else constant, should exhibit a larger market share for premiumgrade gasoline than otherwise.

On the other hand, a state with a higher unit tax on gasoline relative to that of its neighboring states is expected to experience a net loss in cross-border sales. That is, when the TAX DIFFERENTIAL ${ }_{i t}$ variable is positive and large in magnitude, state $i$ is less likely to attract consumers from other states and is more likely to cause its residents to shop in neighboring states. Because state $i$ attracts fewer cross-border shoppers, who are as a group more likely to purchase premium-grade gasoline, the state will experience a decline in the market share for premium-gasoline. Thus, the coefficient on the TAX DIFFERENTIAL $_{i t}$ variable is expected to be negative in the premium-grade model and positive in the regular-grade model. 
The purchase of gasoline grade should also depend on the characteristics of the drivers within a state. Men may be more likely to own sports cars that require high octane gasoline, so the coefficient on the percent male variable is expected to be positive in the premium-grade model and negative in the regular-grade model. The same can be said of younger drivers. The market share of premium gasoline is expected to fall as the percentage of licensed drivers over the age of sixty-four increases, suggesting a negative sign in the premium-grade model and a positive sign in the regular-grade model. The effect of per capita income is not as straight-forward. While individuals with more income may be more likely to purchase sports cars requiring premium-grade gasoline, individuals with low income, as a group, may purchase more premium-grade gasoline for a different reason. High octane gasoline is often used to eliminate engine knock, which is a symptom of older, high-mileage automobiles. Individuals with higher incomes may own newer cars that do not suffer from engine knock. Thus, the sign of the coefficient on per capita income could be negative or positive. If older vehicles are used on a daily basis and if consumers are knowledgeable of the benefits of high octane gasoline for ridding of engine knock, then the coefficient on per capita income should be negative in the premium-grade model and positive in the regular-grade model.

The results from the two-way fixed effects model using Ordinary Least Squares (OLS) estimation for both grades of gasoline are presented in Table 4.3. The coefficients of the variables controlling for driver characteristics are of the anticipated sign, although not always significant. The sales tax is shown to be an insignificant determinant of the market share for both regular-grade and premium-grade gasoline. Surprisingly, the unit tax is also statistically insignificant. Furthermore, it is of the wrong sign in the premium- 
Table 4.3

Ordinary Least Squares Model (OLS)

1994 - 2001

\begin{tabular}{|c|c|c|}
\hline Dependent Variable & $\begin{array}{l}\text { Market Share for } \\
\text { Regular Gasoline }\end{array}$ & $\begin{array}{l}\text { Market Share for } \\
\text { Premium Gasoline }\end{array}$ \\
\hline Unit Tax (cents) & $\begin{array}{l}-0.006 \\
(0.03)\end{array}$ & $\begin{array}{l}-0.143 \\
(1.60)\end{array}$ \\
\hline $\begin{array}{l}\text { Average Tax Differential } \\
\text { of Bordering States (cents) }\end{array}$ & $\begin{array}{l}0.487^{* *} \\
(2.23)\end{array}$ & $\begin{array}{l}-0.103 \\
(1.24)\end{array}$ \\
\hline Sales Tax Rate (\%) & $\begin{array}{l}-0.017 \\
(0.03)\end{array}$ & $\begin{array}{l}0.123 \\
(0.66)\end{array}$ \\
\hline Per Capita Income $(\$ 1,000)$ & $\begin{array}{l}0.362 \\
(1.29)\end{array}$ & $\begin{array}{c}-0.206^{*} \\
(1.93)\end{array}$ \\
\hline Percent Male (\%) & $\begin{array}{l}-0.671^{\star \star} \\
(2.20)\end{array}$ & $\begin{array}{c}0.327^{\star \star *} \\
(2.81)\end{array}$ \\
\hline Percent of Population < 35 (\%) & $\begin{array}{c}-0.390^{\star \star \star} \\
(2.65)\end{array}$ & $\begin{array}{l}0.111^{\star *} \\
(1.98)\end{array}$ \\
\hline Percent of Population > $64(\%)$ & $\begin{array}{l}0.457 \\
(1.50)\end{array}$ & $\begin{array}{l}-0.076 \\
(0.65)\end{array}$ \\
\hline Constant & $\begin{array}{c}99.401^{\star \star \star} \\
(4.10)\end{array}$ & $\begin{array}{l}9.719 \\
(1.05)\end{array}$ \\
\hline $\begin{array}{l}\text { State Fixed Effects } \\
\text { Period Fixed Effects }\end{array}$ & $\begin{array}{l}\text { Yes } \\
\text { Yes }\end{array}$ & $\begin{array}{l}\text { Yes } \\
\text { Yes }\end{array}$ \\
\hline $\begin{array}{l}\text { R-squared } \\
\text { Log-Likelihood } \\
\text { Observations }\end{array}$ & $\begin{array}{c}0.902 \\
-849.100 \\
360\end{array}$ & $\begin{array}{c}0.964 \\
-501.760 \\
360\end{array}$ \\
\hline
\end{tabular}

Absolute t-ratios in parenthesis. Significance levels of $1 \%, 5 \%$, and $10 \%$ are denoted by ${ }^{* *},{ }^{* *}$, and ${ }^{*}$, respectively. 
grade model. While of the correct sign in both models, the tax differential variable is significant in the regular-grade model only.

The results from the OLS estimation provide little evidence in support of the Alchian and Allen theorem. However, the OLS estimator has been shown to be either biased and inconsistent or inefficient when spatial dependence exists. ${ }^{34}$ Spatial dependence occurs when observations are related through unobservable geographic variables. When specifying spatial dependence, the model may contain a spatially autoregressive dependent variable, or it may incorporate a spatial autoregressive process in the error term. The first model, known as the spatial lag model takes the following form:

$$
\mathrm{Y}=\rho \cdot \mathrm{W} \cdot \mathrm{y}+\mathrm{X} \cdot \beta+\varepsilon
$$

where $\mathrm{Y}$ is the $\mathrm{N} \times 1$ dependent variable, $\mathrm{X}$ is the $\mathrm{N} \times \mathrm{K}$ matrix of exogenous variables, $\mathrm{W}$ is the $\mathrm{N} \times \mathrm{N}$ spatial weighting matrix, and rho is the spatial autoregressive coefficient. The second model, known as the spatial error model, can be represented by:

$$
\mathrm{Y}=\mathrm{X} \cdot \beta+\varepsilon ; \varepsilon=(\mathrm{I}-\lambda \cdot \mathrm{W})^{-1} \cdot v
$$

where lambda is the unobserved spatial error correlation coefficient and $v$ is the $\mathrm{N} \times 1$ vector of IID random variables component of the error terms.

\footnotetext{
${ }^{34}$ See Anselin (1988), Dubin (1988), Case (1991), Anselin and Hudak (1992), Baltagi (2001), Elhorst (2003), and Lacombe (2004) for more on specification and estimation of models with spatial dependence.
} 
Equation 4.1 is re-estimated using both the spatial lag model and the spatial error models in MATLAB using the sar_panel and sem_panel functions found in the spatial econometrics toolbox. ${ }^{35}$ One drawback of the spatial two-way fixed effects model is that the coefficients of the fixed effects and period effects may not be estimated consistently. ${ }^{36}$ Fortunately, this problem does not spill over to the other coefficients of the X-matrix. The weighting matrix used to control for spatial dependence is based on first degree contiguity (geographic neighbors). ${ }^{37}$ Estimation results for the spatial lag model and spatial error model are presented in Tables 4.4 and 4.5, respectively.

According to the results of both the spatial lag and spatial error models, spatial dependence does appear to be present in the data. The spatial autoregressive coefficient, rho, is positive and significant at the one-percent level for both gasoline grades, suggesting that when the market share for a particular gasoline grade is high in a neighboring state the market share in the home state is also large. This seems to be intuitive because preferences and habits may vary regionally. Lambda, the spatial error correlation coefficient, is also positive and significant in the spatial error model, suggesting that there is spatial autocorrelation in the measurement errors or in the variables not crucial to (and therefore not included in) the model. ${ }^{38}$ While the results of the two models of spatial autocorrelation are largely similar, only those from the spatial lag model will be discussed below, for two reasons. First, the log-likelihood statistic is larger for the spatial lag model. Second, and more importantly, the interpretation of the

\footnotetext{
${ }^{35}$ The spatial econometric toolbox is a public domain set of functions maintained by James LeSage. The toolbox can be downloaded for free at www.spatial-econometrics.com. The code for the spatial panel models was developed by J. Paul Elhorst.

${ }^{36}$ See Elhorst (2003), pages 250-251.

${ }^{37}$ Each bordering state is given equal weight in this specification. Alternatively, the weights could be based border length, population demographics, among others. While leading to some minor changes in the value of the coefficients, using one of these alternatives is not likely to impact the results significantly.

${ }^{38}$ See Anselin and Bera (1998).
} 
Table 4.4

Spatial Lag Model (SAR)

1994 - 2001

\begin{tabular}{|c|c|c|}
\hline Dependent Variable & $\begin{array}{l}\text { Market Share for } \\
\text { Regular Gasoline }\end{array}$ & $\begin{array}{l}\text { Market Share for } \\
\text { Premium Gasoline }\end{array}$ \\
\hline Unit Tax (cents) & $\begin{array}{l}-0.227^{\star \star *} \\
(10.99)\end{array}$ & $\begin{array}{l}0.157^{\star \star \star} \\
(16.93)\end{array}$ \\
\hline $\begin{array}{l}\text { Average Tax Differential } \\
\text { of Bordering States (cents) }\end{array}$ & $\begin{array}{l}0.672^{\star \star *} \\
(8.01)\end{array}$ & $\begin{array}{l}-0.359^{* \star *} \\
(9.70)\end{array}$ \\
\hline Sales Tax Rate (\%) & $\begin{array}{l}-0.377 \\
(1.05)\end{array}$ & $\begin{array}{l}0.253 \\
(1.60)\end{array}$ \\
\hline Per Capita Income $(\$ 1,000)$ & $\begin{array}{c}0.473^{\star \star *} \\
(4.16)\end{array}$ & $\begin{array}{c}-0.370^{* \star *} \\
(7.36)\end{array}$ \\
\hline Percent Male (\%) & $\begin{array}{c}-0.460^{\star *} \\
(2.11)\end{array}$ & $\begin{array}{c}0.440^{\star \star \star} \\
(4.58)\end{array}$ \\
\hline Percent of Population < $35(\%)$ & $\begin{array}{c}-0.255^{\star \star \star} \\
(2.66)\end{array}$ & $\begin{array}{c}0.204^{\star \star \star} \\
(4.83)\end{array}$ \\
\hline Percent of Population > $64(\%)$ & $\begin{array}{l}0.677^{\star \star \star} \\
(3.26)\end{array}$ & $\begin{array}{l}-0.045 \\
(0.49)\end{array}$ \\
\hline Rho & $\begin{array}{l}0.325^{\star \star \star} \\
(9.93)\end{array}$ & $\begin{array}{c}0.359^{\star \star \star} \\
(14.92)\end{array}$ \\
\hline $\begin{array}{l}\text { State Fixed Effects } \\
\text { Period Fixed Effects }\end{array}$ & $\begin{array}{l}\text { Yes } \\
\text { Yes }\end{array}$ & $\begin{array}{l}\text { Yes } \\
\text { Yes }\end{array}$ \\
\hline $\begin{array}{l}\text { R-squared } \\
\text { Log-Likelihood } \\
\text { Observations }\end{array}$ & $\begin{array}{c}0.934 \\
-852.776 \\
360\end{array}$ & $\begin{array}{c}0.968 \\
-700.303 \\
360\end{array}$ \\
\hline
\end{tabular}

Absolute t-ratios in parenthesis. Significance levels of $1 \%, 5 \%$, and $10 \%$ are denoted by ${ }^{\star \star *},{ }^{* \star}$, and ${ }^{*}$, respectively. 
Table 4.5

Spatial Error Lag Model (SEM)

1994 - 2001

\begin{tabular}{|c|c|c|}
\hline Dependent Variable & $\begin{array}{l}\text { Market Share for } \\
\text { Regular Gasoline }\end{array}$ & $\begin{array}{l}\text { Market Share for } \\
\text { Premium Gasoline }\end{array}$ \\
\hline Unit Tax (cents) & $\begin{array}{l}-0.348^{* \star *} \\
(16.57)\end{array}$ & $\begin{array}{l}0.252^{\star \star \star} \\
(21.17)\end{array}$ \\
\hline $\begin{array}{l}\text { Average Tax Differential } \\
\text { of Bordering States (cents) }\end{array}$ & $\begin{array}{c}0.620 * \star \star \\
(10.92)\end{array}$ & $\begin{array}{c}-0.375^{\star \star \star} \\
(10.95)\end{array}$ \\
\hline Sales Tax Rate (\%) & $\begin{array}{l}-0.292 \\
(1.04) \\
\end{array}$ & $\begin{array}{l}0.107 \\
(0.64) \\
\end{array}$ \\
\hline Per Capita Income $(\$ 1,000)$ & $\begin{array}{c}1.215^{\star \star \star} \\
(12.38)\end{array}$ & $\begin{array}{c}-0.713^{\star \star \star} \\
(12.50)\end{array}$ \\
\hline Percent Male (\%) & $\begin{array}{l}-0.211 \\
(1.27)\end{array}$ & $\begin{array}{c}0.357^{\star \star \star} \\
(3.61)\end{array}$ \\
\hline Percent of Population < $35(\%)$ & $\begin{array}{l}-0.082 \\
(0.99)\end{array}$ & $\begin{array}{c}0.184^{\star \star \star} \\
(3.81)\end{array}$ \\
\hline Percent of Population > $64(\%)$ & $\begin{array}{c}0.377^{\star *} \\
(2.26)\end{array}$ & $\begin{array}{l}-0.007 \\
(0.08)\end{array}$ \\
\hline Lambda & $\begin{array}{c}0.755^{\star \star \star} \\
(24.89)\end{array}$ & $\begin{array}{c}0.583^{\star * *} \\
(13.39)\end{array}$ \\
\hline State Fixed Effects & Yes & Yes \\
\hline Period Fixed Effects & Yes & Yes \\
\hline $\begin{array}{l}\text { R-squared } \\
\text { Log-Likelihood } \\
\text { Observations }\end{array}$ & $\begin{array}{c}0.944 \\
-752.852 \\
360 \\
\end{array}$ & $\begin{array}{c}0.961 \\
-535.464 \\
360 \\
\end{array}$ \\
\hline
\end{tabular}

Absolute t-ratios in parenthesis. Significance levels of $1 \%, 5 \%$, and $10 \%$ are denoted by ${ }^{* *},{ }^{* *}$, and ${ }^{*}$, respectively. 
spatial autocorrelation in the spatial lag model is intuitive in this case; purchases of gasoline in a given state should be fairly similar to the purchases in a neighboring state.

The estimated coefficients of all variables in the two-way fixed effects spatial lag model are of their predicted sign and, with the exception of the percent of licensed drivers over the age of sixty-four in the premium-grade model, are of the expected significance. Similar to the results of the OLS estimation, men and young drivers purchase proportionately more premium-grade gasoline. Drivers over the age of sixty-four tend to purchase proportionately more regular-grade gasoline relative to drivers aged between thirty-five and sixty-four. An increase in per capita income again appears to be negatively related to the market share of premium-grade gasoline. In particular, a one thousand dollar increase in state per capita income causes the market share of premiumgrade gasoline in that state to fall by 0.370 percentage points. The same increase in income is also associated with a 0.473 percentage point increase in regular-grade gasoline.

The results support the implications of the Alchian and Allen theorem concerning the relative-price effects of unit and ad valorem (sales) taxation. The sales tax, which exerts no influence on relative prices, is shown to have no significant influence on the market shares of either grade of gasoline. Ignoring any cross-border effects, an increase in a state's unit tax on gasoline is predicted to cause an increase in gasoline quality. The results support this prediction, indicating that a one-cent increase of the unit tax on gasoline in a given state will lead to a 0.157 percentage point increase in the market share of premium-grade gasoline and a 0.227 percentage point decrease in the market share of regular-grade gasoline. Based on these estimates and applying the sample mean unit tax 
(45.57 cents), the average state's market share of premium-grade gasoline is about 7.15 percentage points larger than it would otherwise be. This represents over an eighty percent increase in the market share of premium-grade gasoline. The market share of regular-grade gasoline is about 10.34 percentage points less than otherwise, representing a twelve percent decline.

In addition to the relative-price effects detailed above, gasoline unit taxes are also shown to have statistically significant cross-border effects on the purchase of gasoline grade. The cross-border effect, as measured by the coefficient on the TAX DIFFERENTIAL $_{i t}$ variable, is found to be negative in the premium-grade model and positive in the regular-grade model and statistically significant in both models. A one cent increase in the unit tax in a given state, holding constant the tax rates in all the bordering states, leads to a 0.359 percentage point decrease in the market share of premium-grade gasoline and a 0.672 percentage point increase in the market share of regular-grade gasoline. Alternatively, the same outcome could result if a given state holds its unit tax constant and all bordering states reduce their unit taxes on gasoline by one cent.

While the above results are each interesting and important in their own right, it is the net effect of a change in the gasoline unit tax that most interesting. The net effect of a change in the unit tax on gasoline is simply the sum of the estimated coefficients $\beta_{1}$ and $\beta_{2} .{ }^{39}$ First consider a one cent increase in the federal unit tax on gasoline. An increase in the federal tax is equivalent to the case where all states raise their taxes equally, leaving the tax rate differential unchanged and causing $\beta_{2}$ to fall out of the equation. As such, the

\footnotetext{
${ }^{39}$ To arrive at this result, simply take the derivative of equation 4.1 with respect to the unit tax in state $i$.
} 
net effect of a one cent increase in the federal gasoline unit tax is equal to $\beta_{1}$, or 0.157 percentage points for premium-grade gasoline and -0.227 percentage points for regulargrade gasoline.

Next, consider a one cent increase in state i's unit tax, holding constant the gasoline tax in each bordering state. The net effect of a one cent increase in state $i$ will equal $\beta_{1}+\beta_{2}$, or -0.202 percentage points for premium-grade and 0.445 percentage points for regular-grade gasoline. The cross-border effect dominates the relative-price effect of a change in a states unit tax on gasoline $\left(\beta_{2}\right.$ is greater in magnitude than $\left.\beta_{1}\right)$. Thus, the net effect of an increase in a state's unit tax on gasoline is to decrease the market share of premium-grade gasoline in that state. Each of the bordering states will observe a small increase in their market shares of premium-grade gasoline. The effects for regular-grade gasoline are in the opposite direction and slightly larger in magnitude.

The goal of this chapter is not to determine the optimal tax on gasoline; rather it is intended simply to quantify the quality substitution effects of the gasoline excise tax. However, the distortionary effects of the gasoline excise tax warrant consideration of some policy implications. State and federal unit taxes both reduce consumer welfare by altering consumer purchases of gasoline grade. Furthermore, any non-uniform tax across states, either on a per-unit or ad valorem basis, will cause consumer purchases of product quality to adjust due to the cross-border effect, necessarily reducing welfare. Only a uniform ad valorem state tax or, equivalently a federal ad valorem tax, will leave product quality unchanged. It is this latter tax structure that may be preferred (in welfare terms) in the case where the sole purpose of an excise tax is to generate revenue. 
An argument could also be made suggesting that the current excise tax structure is preferable on a welfare basis. Excise taxes, as if often argued by politicians, exist not to raise revenue, although that is a convenient secondary characteristic, but exist as user fees or as a means to deter an action that produces a negative externality on society. Indeed, if voter preferences for environmental quality and highway maintenance do vary by state, then it is likely optimal to have a system of non-uniform taxes on gasoline. ${ }^{40}$ Furthermore, unit taxes are preferable to ad valorem taxes in such a scenario because the relative-price and cross-border effects on product quality partially off-set one-another. In a system of only non-uniform ad valorem taxes, the full brunt of the cross-border effect on product quality would be felt by society. Thus, it could be the case that a system of excise taxation similar to the one currently imposed may be a second-best alternative, given a specific revenue constraint.

\subsection{Conclusion}

This chapter explores the impact of unit taxes on the purchase of product quality, as measured by the market shares of gasoline grade, in a federal economy where taxes commonly differ from state to state. The results show that unit taxes can influence the choice of gasoline grade through two channels. First, changes in unit taxes alter the relative price of higher-quality, premium-grade gasoline, causing some consumers to substitute between grades. Second, changes in the interstate tax differential can alter the number of cross-border shoppers into the state. Because cross-border shoppers incur a larger fixed cost of travel than the typical in-state shoppers, which reduces the relative

\footnotetext{
${ }^{40}$ If the Tiebout (1956) model is true at the state level, individuals will "vote with their feet" and move to the state where the constituents' preferences are most in line with their own.
} 
price of higher-quality goods, they are more likely to purchase premium-grade gasoline than in-state shoppers. These two channels through which unit taxes affect product quality are shown to be partially offsetting, with the cross-border effect dominating the relationship. This would suggest that the elasticity of demand for cross-border shoppers is greater than that of in-state consumers.

The quality substitution effects were quantified in terms of a one-cent increase in the federal unit tax and a one-cent increase in a single state's unit tax. An increase in a single state's unit tax is shown to distort consumer purchases of gasoline grade through both channels. The net effect of such an increase is to decrease the market share of premium-grade gasoline by 0.202 percentage points and increase the market share of regular-grade gasoline by 0.445 percentage points. An increase in the federal tax is equivalent to an equal increase in the tax across all states. Such a tax increase causes no interstate tax differentials and therefore does not cause cross-border shopping across states. The impact of a one-cent increase in the federal unit tax on product quality is to increase the market share of premium-grade gasoline by 0.157 percentage points and to decrease the market share of regular-grade gasoline by 0.227 percentage points.

These results suggest some policy implications concerning the imposition of excise taxes. Unit taxes at both the state and federal level are shown to distort consumer purchases of quality, necessarily reducing consumer welfare. Non-uniform taxation (both per-unit and ad valorem) across states leads to additional distortions in product quality through cross-border shopping, again reducing welfare. It is argued that only a federal ad valorem tax leaves product quality unchanged. Thus, when the sole purpose of a tax is to generate revenue, a federal ad valorem tax or a uniform state ad valorem tax may be 
preferable in a welfare sense. However, if voter preferences for environmental quality and highway maintenance vary across states, a tax system similar to the current one may be best. 


\section{Chapter 5 \\ Federal Grants, Earmarked Revenues, and Budget Crowd-Out: State Highway Funding}

\subsection{Introduction}

State highway projects are largely funded through two sources: state revenues from earmarked taxes on motor-fuels, vehicles, and tolls and revenues from federal highway grants. Increases in either earmarked tax revenues or federal grant money can crowd-out general funds. The goal of this chapter is to determine the degree of crowd-out or crowdin for the case of state highway expenditure. The previous literature on highway spending attempts to measure by how much highway spending increases due to an increase in federal grants. This literature has neglected the influence of earmarked revenues on highway spending.

Until recently, the literature on highway spending also failed to properly incorporate the unique features of the budgetary process. Early studies of highway spending empirically model state highway expenditure as a function of federal grant receipts and a set of control variables. However, as Gamkhar (2000 \& 2003) describes, federal grant expenditures are endogenous. The Federal Highway Administration (FHWA) first apportions federal highway aid for state use and states can then reserve (or obligate) these funds for a specific highway project. Federal grants are not awarded upfront. Rather, highway aid is given to the states as a reimbursement. States first decide how much to spend on highway construction and maintenance based on federal aid obligations, and federal aid expenditure is determined by the level of state expenditure. To incorporate the endogenous nature of federal aid expenditure, an instrumental variable 
estimator is used. In particular, federal highway obligations and state payments to the federal highway trust fund are used as instruments for federal highway grants.

The chapter proceeds as follows: Section 5.2 discusses the past literature analyzing intergovernmental grants and the literature on tax earmarking. The state highway funding process, including a discussion of the major changes imposed by the Intermodal Surface and Transportation Efficiency Act in 1991, is reviewed in Section 5.3. The empirical model, data, and results are presented in Section 5.4 and concluding remarks are offered in Section 5.5.

\subsection{Literature Review}

\subsubsection{Intergovernmental Grants}

Nearly twenty-nine percent of state revenues during the fiscal year ending in 2002 came in the form of federal grants. ${ }^{41}$ Federal grants can be matching or non-matching. Nonmatching grants are simply lump-sum transfers. Matching grants require states to fund a specified percent of total project expenditures, creating both income and price effects on the demand for local public goods. For example, most federal highway funds are awarded on an eighty percent federal — twenty percent state matching basis. Many matching grant programs impose a cap on the amount a state can receive. Thus, if a state spends beyond the amount necessary to reach the cap, the grant can be treated as if it were non-matching because the matching rate is not binding.

When considering the simple case of a non-matching grant (or a non-binding matching grant), the theoretical model of Bradford and Oates (1971) suggests that states should treat grant receipts as if they are simply increases in statewide private income. As

${ }^{41}$ Census of Governments, 2002. 
such, the increase in state spending out of grant receipts should equal the marginal propensity of local governments to spend out of income, which is, according to Hines and Thaler (1995), about five to ten percent for state governments. However, estimates of the actual proportion used for state spending often approach the one hundred percent mark. This anomaly between the theoretical predictions and actual observations has been coined the "flypaper effect" because money sticks to where it hits.

Much of the empirical work estimating the extent of the flypaper effect examines the relationship between additional grant receipts earmarked for the provision of a given public good or service and the respective increase state expenditures. Gramlich (1977), Oates (1994), Hines and Thaler (1995), and Bailey and Connolly (1998) each provide comprehensive reviews of the empirical literature covering the flypaper effect. Table 5.1 reproduces tables by Hines and Thaler (1995) and Knight (2000) displaying the summary findings of this literature. As can be seen in Table 5.1, a one dollar increase in grants receipts increases state expenditures by between twenty-five cents and one hundred seventy cents. However, the majority of the estimates are between forty cents and sixtyfive cents.

Because this chapter examines state highway revenues and expenditures, I will discuss only those studies related to this area of state spending. Case, Hines, and Rosen (1993) consider overall state expenditures and four specific categories of state expenditure: state administration, health and human services, education, and highways. Before controlling for state spillover effects, their estimates indicate that a dollar of grant receipts increases total state expenditures by a little over a dollar. However, according to their model of choice, which controls for spatial dependence across states, an increase in 
Table 5.1

Some Estimates of the Flypaper Effect

\begin{tabular}{|l|l|c|}
\hline \multicolumn{1}{|c|}{ Author } & \multicolumn{1}{|c|}{ Sample } & $\begin{array}{c}\text { Change in spending } \\
\text { as grant changes }\end{array}$ \\
\hline Inman (1971) & State grants to 41 cities, 1967 & 1.00 \\
Weicher (1972) & State grants to 106 municiple governments, 1962 & 0.90 \\
Weicher (1972) & State grants to 106 school districts, 1962 & 0.40 \\
Gramlich and Galper (1973) & Federal grants to local and state governments, & 0.43 \\
Gramlich and Galper (1973) & 1954-1972 (time-series) & 0.25 \\
Bowman (1974) & Federal and state aid to 10 large urban governments, \\
Bowman (1974) & 1962-1970 (panel) & 1.06 \\
Feldstein (1975) & Federal education grants to 55 WV school districts, 1970 & 0.50 \\
Grossman (1990) & State grants to 55 WV school districts, 1970 & 0.60 \\
Olmsted, Denzau and Roberts (1993) & Federal and state aid to 344 MO school districs, 1980 & 1.70 \\
Case, Hines, and Rosen (1993) & Federal grants to 48 states, 1970-1985 (panel) & 0.58 \\
Becker (1996) & Federal grants to state and local governments, & 0.65 \\
Gamkar and Oates (1996) & 1977-1986 (panel) & 0.61 \\
\hline
\end{tabular}

Reproduced from Hines and Thaler (1995) and Knight (2000)

grant receipts causes only a sixty-five cent rise in total state expenditures. The authors also find evidence of the flypaper effect in the categorical specifications, including the highway spending specification. Meyers (1987), modeling federal highway grants as endogenous, indicates that a dollar of federal grant receipts increases state expenditures by only thirty-seven cents. Although this response is fairly small, it is still much larger than the expenditure response of an increase in personal income, offering further evidence of the flypaper effect.

Gamkhar (2003) uses an empirical model that better represents the reimbursement nature of the federal highway grant process. The Federal Highway Administration (FHA) first apportions federal highway aid to each state. ${ }^{42}$ Only then can states obligate

\footnotetext{
${ }^{42}$ Apportionments are based on the formula described in the highway authorization bill. The formulas vary based on the highway program (primary, secondary, urban, and interstate systems); however, the formulas
} 
(or reserve) these funds for a specific highway project. Once obligated, states have upwards of eight years before the state's claim to the funds expires. Federal grants are not awarded up-front; rather, highway aid is given to the states as a reimbursement. States first decide how much to spend on highway construction and maintenance based on federal aid obligations, and federal aid expenditure is determined by the amount of state expenditures. Because states base highway expenditure decisions on the amount of funds that have been obligated to the state, Gamkhar suggests that obligations (current year plus the one- and two-year lagged obligations) be used as the federal aid variable instead of current year federal highway grant expenditure.

Gamkhar (2003) uses a panel data set of state-level highway expenditure data for the time period 1978-1990 to measure the effect of federal highway grants on state and local highway expenditure. His results indicate a substantial flypaper effect. The sum of the effects of the current plus the one- and two-year lagged obligations indicate that a one dollar increase in federal highway obligations causes state expenditures to rise by about seventy-eight cents. A one dollar increase in per capita income is shown to lead to only a two cent increase in state highway expenditures. In a closely related paper, Gamkhar (2000) estimates an asymmetric response to increases and decreases in federal highway obligations. $^{43}$ He finds the combined effect from current and lagged obligations on state and local highway spending is eighty-seven cents on the dollar. Although he does find some evidence of asymmetry in the response to increases and decreases in federal aid, it is small and not economically significant.

include the following factors: land area, urban and rural population, postal mileage, vehicle miles traveled, interstate lane mileage, and payments into the highway trust fund, among others.

${ }^{43}$ See also Gamkhar and Oates (1996) for more on the asymmetric responses to federal grant receipts. 
Gamkhar's (2000 and 2003) estimates of the response of state highway expenditures to an increase in grant receipts are much larger than others have observed. However, previous studies had not used obligations as the grant variable. In order to better compare his results with the earlier studies, Gamkhar (2003) re-estimates his results using federal highway grants as the aid variable. His results from this specification are much closer to those found in the earlier literature, indicating only a thirty-seven cent increase in state highway spending.

Knight (2002) offers a complementary explanation of the relationship between federal highway grants and state and local highway expenditures. Because theory predicts that states should treat an increase in grant receipts like an increase in personal income, Knight claims that federal grants should crowd-out a large portion of state funds. ${ }^{44}$ Thus, evidence of the flypaper effect is analogous to finding little evidence of budget crowd-out; hence, the literature has found little empirical evidence of budget crowd-out. He attributes this lack of evidence for budget crowd-out to the endogeneity of federal grants, claiming that the actions of political representatives may reflect unobserved constituent preferences. Knight proposes a legislative bargaining model to correct for this bias.

Like the highway studies discussed above, Knight (2002) attempts to empirically estimate by how much state highway expenditures rise when federal highway grant receipts increase. He uses data on forty-seven states for the time period 1983 to 1997. Before correcting for the endogeneity problems, his OLS results suggest budget crowdin. However, the results from the 2SLS and LIML specifications provide evidence of crowd-out. As instruments for grant receipts, Knight uses the proportion of

\footnotetext{
${ }^{44}$ See Bradford and Oates (1971).
} 
representatives serving on the transportation committee, the percent of representatives of the majority party, and average tenure for both the house and senate.

As will be described below, state earmarking is also predicted to cause budget crowd-out. Because state highway spending is funded both through federal highway grants and through state earmarking, highway expenditures provide an interesting case study for budget crowd-out. Indeed, the estimates of Knight (2002) and others may suffer from omitted variable biased since they do not incorporate the earmark financing nature of state tax revenues.

\subsubsection{Public Choice Theory of Earmarking}

Buchanan (1963) defines earmarking as the practice of designating or dedicating specific tax revenues to the financing of specific public services. The number of arguments both for and against the practice of tax earmarking is numerous. The standard criticism of tax earmarking is analogous to the introduction of additional constraints on consumer choice, potentially leading to an inferior consumption bundle. Earmarking, it is argued, limits a politician's ability to adjust public funding to the changing needs of society. Buchanan (1963) points out the short-comings of the consumer demand analogy, arguing that general-fund financing and earmarking be compared as alternative budgetary solutions in a model of government in which the incentives of politicians do not always coincide with those of the constituency. ${ }^{45}$

Buchanan (1963) theoretically compares general-fund financing to earmark financing, ultimately suggesting that earmark financing is the preferable budgetary option. One of Buchanan's major criticisms of general fund financing is that voters are

\footnotetext{
${ }^{45}$ See also McMahon and Sprenkle (1970).
} 
only able to determine the total level of government spending, leaving the relative expenditure across government projects up to the budgetary authority. Because the incentives of the budgetary authority are unlikely to coincide with voter incentives, the relative expenditure levels are unlikely to be in line with voter preferences. The resulting expenditure level under general-fund financing is inefficient. However, under earmark financing voters are able to vote on the level of expenditure for each individual project. ${ }^{46}$

For example, consider a government which produces two goods, highways and education, where voters seek only a one dollar increase in education spending. Under a general-fund financing program where highways and education are funded using, for example, an eighty-twenty tie-in ratio, voters must vote for a five dollar increase in taxes. That is, in order to increase education funding by one dollar, they also (implicitly) vote for a four dollar increase in spending on highways. Under earmark financing, voters could cast two independent votes concerning highway and education funding. As such, the outcome in this simple example would be a one dollar increase in education funding and no change in the level of funding for highways. Clearly, earmark financing is preferable from a voter welfare standpoint in this simple example.

Goetz (1968) modifies Buchanan's theoretical model to allow for a group decision to determine the outcome rather than having it depend on a single individual, as is assumed in the Buchanan model. Goetz's conclusions support those of Buchanan, suggesting that the earmarking process better represents voters' preferences. Buchanan and Brennan (1978) approach the issue of tax earmarking from a constitutional viewpoint. They argue that the use of earmarked tax revenues to finance government

\footnotetext{
${ }^{46}$ Eklund (1972) suggests that the consumer demand analogy, although imperfect, cannot be ignored. The desirability of earmarking, it is argued, must be determined based on the trade-off between a better matching of taxpayers' preferences for public goods and the benefits of redistributive fiscal policies.
} 
projects limits the ability of a government to behave as a Leviathan. Thus, an earmarking arrangement ensures at least a certain level of public services is provided rather than allowing all tax revenues to be wasted by the Leviathan. Additionally, such an arrangement aligns the incentives of the government with those of the voters when the tax base and the government service are tied together (i.e., the gasoline tax and highways). In order to raise additional revenues from the sale of gasoline, the government must provide the roadways desired by the public to encourage them to consume more gasoline and increase tax revenues. ${ }^{47}$

Bos (2000) develops a "planner-taxer-spender" model to analyze earmarking, concluding that the implications of the Buchanan and Brennan argument may not be entirely true. Bos argues that earmarking does not encourage government to behave more efficiently largely due to asymmetric information problems. Furthermore, he argues that earmarking does not bring public expenditures more in line with individual preferences. Because earmarking is not a user-fee principle, the tax increases only the price of the private good on which the tax is applied. Bos explains that an earmarked tax is not the price of the public good. Thus, the payment-consumption link is still broken, leading to inefficient levels of the pubic good.

Buchanan's (1963) article also addresses the intermediate case in which a project is funded both by earmarking and by the general fund. Specifically, he examines the impact of the introduction of earmarked revenues for a project already financed by the general fund. According to Buchanan's model, the level of project spending could

\footnotetext{
${ }^{47}$ Hsiung (2001) offers a complementary reason for adopting an earmarking arrangement, namely compartmentalization. Earmarking can prevent the problems of a particular budgetary item from spreading to other budgetary items.
} 
increase, decrease, or even stay the same. The outcome depends upon what happens to the allocation of general funds dedicated to the project. The earmarked funds could simply serve as a substitute for allocations from the general funds, causing project spending to at most increase by an amount less than the earmarked revenues. This situation is commonly referred to as crowding-out. On the other hand, the earmarked revenues could crowd-in general funds, where the earmarked revenues actually attract additional allocations from the general fund.

Thus earmarking a tax for a specific public expenditure may not increase expenditure on the earmarked project, contrary to voter expectations. In a general fund financing setting, the implementation of an earmarked tax may simply displace the general funds previously used for the earmarked project. The newly freed-up general funds can now be used for other purposes, such as spending on special-interest. In such a case, a politician is able to increase expenditures on special-interest with little voter opposition. ${ }^{48}$

Although it is possible for an earmarked tax to increase government expenditure on a project other than the one it is earmarked for, it is also possible that additional spending on the earmarked project is politically advantageous in that it maximizes votes for the politician. In such a case, general-funds would not be diverted away from the project, and expenditures on the project would increase by nearly the full amount of the tax revenues. Politicians want to maximize tax revenue in both cases, either to maximize the benefit to special-interest or to maximize the provision of the earmarked project so as to gain as many votes as possible in the up-coming election.

\footnotetext{
${ }^{48}$ See Lee (1997).
} 
Buchanan (1963) explains that, a priori, earmarking is just as likely to cause crowd-in as it is to cause crowd-out. He also suggests that the effect on expenditures is likely to vary by project. Therefore, the answer to how earmarking impacts spending becomes an empirical issue that must be addressed on a case-by-case basis. Deran (1965) attempts to shed light on the relationship between earmark financing and the level of expenditure. She hypothesized that increased earmarking would lead to increased expenditures (crowd-in). Using a nonparametric test to evaluate her hypothesis, Deran finds only minimal support for her claim that an increase in the level of earmarking for a project causes expenditures to rise.

Deran also finds evidence that earmarking provisions become embedded in a state's financial structure over time, as the provisions are not re-examined as often as needed. She shows that the amount of earmarked revenue will only initially correspond to the public's level of demand for that service, and over time, there is no reason that the two will equate. More specifically, the testing procedure revealed a downturn bias in earmarked revenues. When demand for an earmarked service is declining, the revenues and expenditures are sticky. This is due to the fact that the tax base is usually separated from those demanding the public service and the overall non-re-evaluative nature of the earmarking process.

Dye and McGuire (1992) also attempt to determine if earmarking increases expenditures dollar-for-dollar. They examine four categories of expenditure: total, education, highways, and aid to local government. Their results suggest that earmarking has little impact on categorical spending, with the exception of aid to local government. An increase in earmarked revenue is found to have no effect on total or education 
spending while increasing highway spending by only nineteen cents, suggesting that there is significant crowd-out. While still suggesting some level of crowd-out in the case of aid to local government, expenditures per dollar of earmarked revenue are much higher; the expenditure response for this category is estimated to be sixty-five cents for every dollar of earmarked revenue.

\subsection{The State Highway Funding Process}

In an effort to add to the empirical literature on earmarking and add to our knowledge of how earmarking and intergovernmental grants impact state and local government expenditures, state highway funding will be analyzed. State highways are funded largely by federal grants and state earmarked taxes. Other sources of revenue for state highway spending include the state's general fund and bond proceeds, among other various

sources. In 2002, nearly forty-eight percent of all revenues used for state highway spending came from state highway-user taxes and fees earmarked for highway use. Nearly twenty-seven percent came in the form of government grants and only about five percent was allocated from the general fund.

According to the three most recent studies, a one dollar increase in federal highway grant receipts causes state and local highway expenditures to rise by between fifty-two and seventy-eight cents. Equivalently, a dollar increase in federal grants crowds-out between twenty-two and forty-eight cents of state funds; see Gamkhar (2000 \& 2003) and Knight (2002) for such examples. The empirical model used in this study borrows largely from Gamkhar (2003) and Knight (2002). 
As explained above, the federal highway grant process follows a reimbursement rule. Funds are first allocated by the FHA, a state then obligates those funds for specified projects and, finally, the FHA distributes highway grant funds after the state has paid for project expenses up-front. ${ }^{49}$ The empirical model used in this chapter improves upon the 2SLS model in Gamkhar (2003). The major difference is that federal obligations (current and lagged) are added as instruments for federal highway grant expenditures in a 2SLS model. In addition, some of the political variables used by Knight (2002) are also included.

Data are obtained from various sources for the time period 1992 - 2002. However, in order to construct the lagged obligations variables, we base the regression analysis on the period from 1994-2002. This time period offers an additional benefit for our study. The Intermodal Surface Transportation Efficiency Act (ISTEA) of 1991 changed many of the rules by which federal highway grants adhere. While a detailed analysis of all the changes in ISTEA is beyond the scope of this chapter, some of the major changes are discussed below. First, ISTEA broadened the scope of approved usages of FHA grants. States can now use federal highway funds for transit projects and bicycle or pedestrian facilities. This rule change has encouraged many states to undertake an assortment of "rails-to-trails" projects.

Other rules introduced in ISTEA altered state management procedures. These rules have the stated purpose of increasing the efficiency of state highway management procedures. According to the new guidelines, states must develop, establish, and implement a systematic process to manage pavements, bridges, safety, congestion, public transit, and intermodal facilities. In other words, states are expected to maintain a

\footnotetext{
${ }^{49}$ States often receive a portion of the federal grant funds as each stage of a project is completed.
} 
process by which authorities can efficiently identify problem areas and quickly develop plans to address those areas.

ISTEA also introduced new planning regulations for statewide and metropolitan projects. The new guidelines left the actual planning process unchanged; however, it did alter the decision-making process. States must consider twenty-three different factors and metropolitan planning organizations (MPOs) must consider fifteen factors when deciding between transportation plans. Additionally, funding must be identified for all projects contained within the first three years of a plan. States and MPOs are also required to have sufficient funds available for on-going projects. ${ }^{50}$

\subsection{Empirical Data and Results}

The data used in this study are a panel of forty-eight states in the continental United States for the period 1994-2002 (obligations data starts in 1992). The panel data allow for the ability to control for state specific factors, such as weather and isolated cases of state budget crisis. The empirical results discussed below are based on a two-stage least squares regression model where the first- and second-stage equations are described by the following:

$$
\begin{aligned}
& \text { FHAGRANT it }=\beta_{0}+\beta_{1} \cdot \mathrm{OB} i t+\beta_{2} \cdot \mathrm{OB} 1_{i t}+\beta_{3} \cdot \mathrm{OB} 2_{i t}+\beta_{4} \cdot X_{i t}+\sum_{i=1}^{48} \alpha_{i} \cdot \mathrm{S}_{i}+v_{i t} \\
& \operatorname{STATEEXP}_{i t}=\beta_{0}+\beta_{1} \cdot \text { FHAGRANT }_{i t}+\beta_{2} \cdot \text { EARMARK }_{i t}+\beta_{3} \cdot \Gamma_{i t}+\sum_{i=1}^{48} \alpha_{i} \cdot S_{i}+\varepsilon_{i t}
\end{aligned}
$$

\footnotetext{
${ }^{50}$ A full-text version of the ISTEA is available at http://iti.acns.nwu.edu/clear/infr/istea_lst.html.
} 
In the first stage, federal highway grants received (FHAGRANT) are regressed on the current year and the one- and two-year lagged obligations (OB, OB1, and $\mathrm{OB} 2)$, a set of other control variables $(\mathrm{X})$, and state dummy variables (s). In the second stage, state highway expenditures (STATEEXP) are regressed on the instrumented variable federal highway grants received (FHAGRANT), state revenues earmarked for highway spending (EARMARK), a set of other control variables $(\Gamma)$, and state dummy variables $(\mathrm{s}){ }^{51}{ }^{5}$ The descriptive statistics and sources for all of the variables used in the study are provided in Table 5.2. All dollar values are per capita and are reported in constant year 2000 dollars. State highway expenditures per capita averaged three hundred sixty-seven dollars, federal highway grant receipts averaged one hundred four dollars per capita, and state taxes earmarked for highways averaged one hundred ninety dollars per capita during the sample period.

Table 5.3 presents the estimation results. ${ }^{52}$ The estimates are corrected for autocorrelation through an AR1 process. Columns two and three report the results from the first-stage regression. As anticipated, federal highway grant receipts are positively affected by obligations (both current and lagged). A one dollar increase in obligations in the current year is shown to increase federal highway grants by eighty-five cents over a three year period (current year and the following two years). States that pay large sums into the federal highway trust fund - that is, those states where a large sum of federal gasoline tax revenue is earned-are shown to gain in the form of increased federal

\footnotetext{
${ }^{51}$ Because states generally spend beyond the level required to reach the cap on federal funds, highway grants are treated as non-matching. This practice is common in the literature (Gamkhar $2000 \& 2003$, Knight 2002, among others).

${ }^{52}$ Case, Hines, and Rosen (1993) suggest that state expenditures are spatially dependent. Spatial autocorrelation models were examined here; however, the spatial parameters were never significant using weighting matrixes based on contiguity and per capita highway spending.
} 
Table 5.2

Variable Definitions, Descriptive Statistics, and Sources*

1994-2002

\begin{tabular}{|c|c|c|c|c|c|c|}
\hline Variable & Definition & Mean & Std.Dev. & Minimum & Maximum & Source \\
\hline STATE_EXP & State highway disbursements $(\$)$ & 367.0858 & 126.8734 & 189.7096 & 908.8871 & [1] \\
\hline FHA_GRANT & Federal Highway grants received(\$) & 104.1003 & 56.4897 & 37.4119 & 401.4232 & [1] \\
\hline EARMARK & State revenues earmarked for highway spending (\$) & 190.2327 & 52.0225 & 52.9680 & 448.4151 & [1] \\
\hline $\mathrm{OB}$ & Federal funds obligated for state highway use $(\$)$ & 115.4627 & 61.8667 & 43.9731 & 450.2419 & [1] \\
\hline OB_1 & 1-year lagged obligations (\$) & 107.5773 & 57.2513 & 42.0963 & 417.0164 & [1] \\
\hline $\mathrm{OB} \_2$ & 2-year lagged obligations (\$) & 101.3349 & 53.1949 & 40.8859 & 406.3205 & [1] \\
\hline SEN_D & Percent state senate members democrat & 50.5006 & 16.6238 & 0.0000 & 94.1176 & [2] \\
\hline HOU_D & Percent state house members democrat & 50.8083 & 17.2643 & 0.0000 & 88.0000 & [2] \\
\hline DEMGOV & Dummy variable $=1$ if democrat & 0.3681 & 0.4828 & 0.0000 & 1.0000 & [3] \\
\hline SEN_TRANS & Percent of senate members on transportation authorization committee & 12.3843 & 22.6567 & 0.0000 & 100.0000 & [3] \\
\hline HOU_TRANS & Percent of house members on transportation authorization committee & 2.8044 & 6.2432 & 0.0000 & 28.5714 & [3] \\
\hline TFUND_PAY & State payments into the federal highway trust fund & 1.2226 & 0.4902 & 0.5620 & 4.0917 & [1] \\
\hline OTH_GRANT & Non-highway grants received & 942.3928 & 241.9741 & 25.6204 & 1881.0121 & [4] \\
\hline INCOME & Per capita income $(\$ 1000)$ & 26.6841 & 4.1345 & 18.9292 & 41.4950 & [5] \\
\hline URATE & Unemployment rate & 4.7049 & 1.1718 & 2.2000 & 8.9000 & [5] \\
\hline DENSITY & Population density & 182.5781 & 248.6123 & 4.9463 & 1156.1618 & [5] \\
\hline VEHICLE & Registered vehicles per capita & 0.8222 & 0.1245 & 0.4778 & 1.2395 & [1] \\
\hline DRIVERS & Licensed drivers per capita & 0.6863 & 0.0509 & 0.5621 & 0.8589 & [1] \\
\hline TRAVEL & Miles traveled per capita & 0.0102 & 0.0017 & 0.0061 & 0.0181 & [1] \\
\hline $\begin{array}{l}\text { [1] Highway St } \\
\text { [2] Book of the } \\
\text { [3] Almanac of } \\
\text { [4] Census of } \\
\text { [5] Bureau of }\end{array}$ & $\begin{array}{l}\text { istics, Federal Highway Administration, various years } \\
\text { tates } \\
\text { merican Politics } \\
\text { vernments } \\
\text { onomic Analysis }\end{array}$ & & & & & \\
\hline
\end{tabular}


highway grants. This relationship seems intuitive because those states where federal gasoline tax revenue is high will obviously have high demand for highways, lending to the need for additional funds to support highways. The percent of state representatives in the House serving on the transportation authorization committee positively impacts federal highway grants, suggesting that those states with more political power over the federal highway program are able to allocate more funds toward the constituents of their home district. Finally, population density is negatively related to federal highway grants. This finding may suggest that there are economies of scale in the provision of highways.

Columns four and five of Table 5.3 report the second-stage regression. This regression is intended to determine the level of crowding-out that occurs in state highway funding due to state earmarked funds and due to federal grant receipts. State earmarked taxes are also shown to have cause little to no crowding-out. A one dollar increase in state earmarked taxes leads to an estimated ninety-four cent rise in state highway spending. This estimate is much larger than Dye and McGuire's (1992) finding that each dollar of earmarked revenue increases state highway expenditures by only nineteen cents. The results presented here should be considered superior to those of Dye and McGuire as this study better controls for the all the characteristics of the state funding process whereas the earlier study does not.

A one dollar increase in federal grant receipts is estimated to cause a rise in state highway spending by about seventy-five cents, suggesting that each dollar of federal grant money crowds-out twenty-five cents of state funds. However, this finding is not statistically different from the case of no crowding - the estimate is not statistically different from a value of one. Although positively related to state highway spending, 
income is found to be statistically insignificant. The insignificant impact of personal income and the near one-for-one relationship between federal grants and state highway spending is consistent with the flypaper effect found in previous studies.

Table 5.3

State Highway Expenditures

1994-2002

\begin{tabular}{|c|c|c|c|c|}
\hline \multirow{3}{*}{ Dependent Variable } & \multicolumn{4}{|c|}{ 2SLS-AR1 } \\
\hline & \multicolumn{2}{|c|}{ FHA_GRANT } & \multicolumn{2}{|c|}{ STATE_EXP } \\
\hline & Coefficient & abs. t-stat & Coefficient & abs. t-stat \\
\hline OB & $0.3113^{\star \star \star}$ & 6.161 & & \\
\hline OB_1 & $0.3266^{* \star *}$ & 6.872 & & \\
\hline OB_2 & $0.2145^{\star * *}$ & 3.788 & & \\
\hline FHA_GRANT & & & $0.7553^{\star * *}$ & 2.834 \\
\hline EARMARK & -0.0002 & 0.004 & $0.9384^{\star \star \star}$ & 5.483 \\
\hline$\overline{\mathrm{OTH} \text { GRANT }}$ & -0.0060 & 0.485 & -0.0009 & 0.023 \\
\hline TFUN̄D PAY & $0.1966^{\star \star \star}$ & 2.678 & 0.1274 & 0.553 \\
\hline INCOME & -1.6965 & 0.994 & 1.7895 & 0.302 \\
\hline URATE & 0.8000 & 0.565 & 4.4529 & 0.957 \\
\hline DENSITY & $-0.4948^{\star \star \star}$ & 2.712 & 0.3873 & 0.578 \\
\hline VEHICLES & 28.3441 & 1.400 & -105.0319 & 1.601 \\
\hline DRIVERS & -7.3679 & 0.166 & -123.3166 & 0.863 \\
\hline TRAVEL & 369.0158 & 0.151 & -8978.2858 & 1.157 \\
\hline TREND & $2.0035^{\star}$ & 1.792 & $8.6229 \star \star$ & 2.078 \\
\hline SEN_D & 0.2567 & 1.143 & -0.6239 & 0.822 \\
\hline HOU_D & 0.1430 & 0.590 & 0.2967 & 0.368 \\
\hline DEMGOV & 3.3525 & 1.070 & 2.9286 & 0.289 \\
\hline SEN_TRANS & -0.0541 & 0.740 & & \\
\hline HOU_TRANS & $0.4732^{\star \star}$ & 2.026 & & \\
\hline Fixed Effects & & & & \\
\hline R-square & & & & \\
\hline Observations & & & & \\
\hline
\end{tabular}

The estimated impact of a dollar of federal grants is very similar to Gamkhar's (2000 \& 2003) estimate of the combined impact of current and lagged obligations. He estimates that a dollar increase in obligations eventually increases state expenditures by between seventy-eight and eighty-seven cents. However, his results for federal grants in the 2SLS estimation fall to only thirty-seven cents per dollar of grant receipts. When 
obligations are used as an instrument for federal highway grants, the impact of a dollar of federal grants is shown to be similar to the estimates in Gamkhar's studies, where obligations are used as the federal aid variable. Thus, when federal highway grants are correctly instrumented, the measured effect of an increase in grants rises to levels where little crowding-out is observed.

Given the changes to the federal highway grant process introduced by ISTEA, it is worth-while to identify if the new rules have changed how state highway spending patterns respond to federal grant receipts. Gamkhar's studies pre-date ISTEA while the sample period here begins after the provisions in ISTEA became effective. The similarity of the results in this study and Gamkhar's studies suggest that the changes made to the federal highway aid program by ISTEA in 1991 have little impact on the response of state spending to federal aid. This is not to suggest that ISTEA has had no impact on state highway spending. The new rules may have enabled states to better identify the areas that need maintenance. Thus, states may not have changed spending habits in general although they may be spending more wisely. This is an area of study that still needs to be addressed.

\subsection{Conclusion}

The goal of this chapter was to examine the relationship between state highway spending and changes in the amount of funding from the two main sources of revenue for state highway programs. State earmarked tax revenues account for nearly forty-eight percent

of all state highway funds, while federal grants and the general fund account for another twenty-seven percent and five percent, respectively. Revenues from earmarking and 
federal grants for highways must be used for highway construction and maintenance, limiting the ability of state authorities to shift funds to special interests. However, because the general fund is fungible, states can theoretically use earmarked revenues and federal aid to substitute for general funds. The results presented in this chapter suggest that this substitution is not occurring in state highway funding.

The estimated impact of a one dollar increase in state tax revenues earmarked for highways is to increase state highway spending by nearly ninety-four cents. An identical increase in federal highway aid is shown to cause state highway spending to rise by about seventy-five cents. Neither of these findings is statistically different from one. Thus, the hypothesis that states increase highway spending dollar-for-dollar can not be rejected. These results imply that the federal highway administration need not be concerned about states using the grant money as a substitute for own spending on highways. Federal highway aid appears to allow states to undertake highway projects that would not have been completed otherwise. Whether or not these projects are efficient is an issue for another study.

The results concerning the response to an increase in federal aid still suggests a large flypaper effect. States are observed to spend more on highways from an increase in federal aid than they would have if the aid had been given to residents in the form of tax relief. The exclusion of state earmarking in prior studies does not seem to bias previous results toward measuring the flypaper effect. State spending also appears to respond fairly equally to increases in federal aid and increases in earmarked tax revenue. Thus, from a public administration perspective, state earmarked funds are identical to federal highway grants. 


\section{Chapter 6 Summary and Conclusion}

Governments have long used excise taxation as a means of raising additional tax revenues and discouraging specific activities. And although the importance of excise taxes as a source of federal government revenue has continued to diminish since the introduction of the income tax in 1913, excise tax policy still appears to be an important tool for policy-makers, particularly for special-interest legislation. ${ }^{53}$ The imposition of an excise tax is fairly straight forward on the surface, especially when compared to the complexities of the income tax. However, the secondary effects and distortions caused by excise taxation are numerous and are often not entirely obvious. Many of these distortions are motivated by special interest groups seeking monopoly power or government subsidies. However, other distortions are the result of individuals trying to avoid taxation. This dissertation contributes to the literature dealing with the various secondary costs of excise taxation.

Chapter 2 analyzes county-level wine and liquor sales in the state of West Virginia to estimate the amount of cross-border shopping that occurs between the state and each of its neighbors. The tax treatment of wine and liquor differs substantially across West Virginia and its five bordering states. The resulting tax differentials ultimately cause many consumers to voluntarily incur the additional expense of traveling across the border where the tax rates (and prices) are lower. The results show that West Virginia observes positive net cross-border sales of wine and liquor in counties bordering

\footnotetext{
${ }^{53}$ See Shughart (1997) for many examples of such legislation.
} 
Pennsylvania and Virginia and negative net cross-border sales in counties bordering Kentucky, Ohio, and Maryland.

It is estimated that over twenty-five percent of all revenue from the mark-up on liquor sales in West Virginia is generated from net cross-border shopping and tourism. While the results of this chapter support the general finding in the literature that crossborder shopping can significantly increase state revenues, the main driving force behind cross-border shopping remains unclear. Consumers may decide to cross-border shop because the tax on a particular good or class of goods is much lower across the border than it is in the consumer's home state. But, because shoppers are likely to purchase other goods while in the store, it is difficult to isolate the reason for cross-border shopping. Thus, an interested and much needed extension of the literature on crossborder shopping concerns the driving force behind cross-border shopping.

Chapters 3 and 4 analyze the quality substitution effects of per-unit excise taxation. Alchian and Allen (1967) theorized that the imposition of a per-unit charge, such as transportation cost or a unit tax, will reduce the relative price of the higher quality version of a good. As the relative price of higher quality falls, consumers choose to buy proportionately more of it. Ad valorem excise taxes, on the other hand, are explained to have no impact on relative prices and should cause no quality substitution. While both per-unit and ad valorem taxes cause substitution in terms of quantity, only the per-unit tax causes substitution in terms of quality.

The results of Chapter 3 make an important contribution to the literature by confirming the theory in a market other than cigarettes. Barzel (1976) conducted the first tests of this theory as applied to unit taxation. His results are supportive of the theory in 
the cigarette market, but he fails to find evidence of the theory in the gasoline and alcohol markets. Since Barzel's original paper was published, three other studies tested the theory in the cigarette market; however, no further work has been developed using other markets. Thus, although the evidence clearly shows support for the theory in the cigarette market, one could still question whether the relationship is unique to cigarette taxation or whether the theory applies generally.

The results of Chapter 3 indicate that the market share of premium-grade and mid-grade gasoline are higher in states with larger unit taxes on gasoline. A one cent increase in the federal or state unit tax is shown to cause a 0.21 percentage point increase in the market share of premium-grade gasoline. Based on the average tax rates in the year 2001, the results indicate that the market share for premium-grade gasoline was over nine percentage points larger and the market share for regular-grade gasoline was about ten percentage points smaller than they would have been without any unit taxes on gasoline. These results clearly indicate support for the theory, suggesting that it can be applied generally to all cases of unit and ad valorem taxation.

In addition to confirming the relationship between taxation and product quality, the results also suggest that the 1997 settlement between the Federal Trade Commission and Exxon had a significant impact on the consumption of premium-grade gasoline. The settlement mandated that Exxon air television commercials and provide pamphlets educating consumers of the lack of benefits obtained by using higher octane gasoline. These efforts are shown to have decreased the market share of premium-grade gasoline by about 1.35 percentage points. 
Higher transportation costs can also cause consumers to substitute toward higher product quality according to the Alchian and Allen (1967) theorem. Assuming that crossborder shoppers travel farther to shop than do in-state shoppers, cross-border shopping can lead to quality substitution. Cross-border shopping was explained to be caused, at least in part, by interstate tax differentials in Chapter 2. Thus, unit taxation can influence the choice of gasoline grade through two channels. First, changes in unit taxes alter the relative price of higher-quality, premium-grade gasoline, causing some consumers to substitute between grades. Second, changes in interstate tax differentials can alter the number of cross-border shoppers. Cross-border shoppers, because they have incurred a higher cost of travel for the trip to the store, are more likely to purchase higher-quality gasoline.

The empirical model of Chapter 4 estimates how the market shares of regulargrade and premium-grade gasoline adjust to changes in the gasoline unit tax. The analysis in this chapter differs from that of Chapter 3 in two primary respects. First, the model in Chapter 4 adds a variable, the average difference in the unit tax rate between the home state and each of its neighbor-states, to control for the effect of cross-border shopping on product quality. The second difference is that the analysis in Chapter 4 uses a model that corrects for spatial autocorrelation.

The results of Chapter 4 show that unit taxation impacts product quality both through the relative-price channel and the cross-border channel. More importantly, it is shown that these effects work in opposite directions with the cross-border effect dominating the relative-price effect. A one cent increase in a state's gasoline unit tax is shown to cause the market share of premium-grade gasoline to rise by 0.157 percentage 
points through the relative-price effect. However, this effect is dominated by the 0.359 percentage point decline in the market share of premium-grade gasoline due to the loss in cross-border shoppers resulting from the tax increase. The total effect of a one cent increase in a state's gasoline tax is a 0.202 percentage point decline in the market share of premium-grade gasoline.

These results suggest some policy implications concerning the imposition of excise taxes. Unit taxes at both the state and federal level are shown to distort consumer purchases of quality, necessarily reducing consumer welfare. Non-uniform taxation (both per-unit and ad valorem) across states leads to additional distortions in product quality through cross-border shopping, again reducing welfare. It is argued that only a federal ad valorem tax leaves product quality unchanged. Thus, when the sole purpose of a tax is to generate revenue, a federal ad valorem tax or a uniform state ad valorem tax may be preferable in a welfare sense. However, if voter preferences vary across states, a tax system similar to the current one may be best.

The results of this chapter also suggest that unit taxes will impact counties within the state differently. Counties on or near the border are likely to observe cross-border shopping. As such, it is likely that only these counties will experience a decline in the market share of premium-grade gasoline when the state increases its tax rate relative to its neighboring states. Thus, for a state with a large gasoline unit tax relative to those of the bordering states, border counties within the state should observe a much lower market share for premium-grade gasoline relative to the market share in non-border counties. This is an implication that can easily be tested in future research if county-level sales data become available. 
Chapter 5 comes full-circle and returns to the incentives of the policy-maker. Chapter 2 presented evidence that cross-border shopping can significantly impact state tax revenues. It was suggested that state policy-makers compete for tax revenues by encouraging cross-border shopping and tourism. The discussion in Chapter 5 focuses on the incentives of the budgeting authority when a project is funded heavily through earmarked state taxes and federal grants. State highways are funded in this fashion. Public choice models of earmarking and intergovernmental grants indicate that there is a potential for both sources of revenue to substitute for general funds. Indeed, Lee (1997) explains that a primary reason for using earmarked taxes is that politicians can raise additional tax revenue to free-up general funds for special-interest legislation and do so without much voter resistance.

Using a two-stage least squares model to incorporate the reimbursement nature of the federal grant process, the response of state spending to changes in the level of federal grants and earmarked revenues is estimated. State highway construction and maintenance planning is largely based on the level of federal funds that have been obligated to the state. Thus, federal obligations (current and lagged) are included as instruments for federal grants. A dollar of obligated funds is found to increase federal aid by about eighty-six cents over a three year period (current plus the following two years). Additionally, each dollar a state pays into the federal highway trust fund increases federal grants to the state by about twenty cents.

The results of the second-stage regression indicate very little crowding-out. Each dollar of earmarked tax revenue is estimated to increase state expenditures by about ninety-four cents. Furthermore, each dollar in federal grant receipts causes state highway 
expenditures to rise by about seventy-five cents. Both of these estimates are not statistically different from a value of one, which would indicate no crowding. This finding of no significant crowding-out in highway funding suggests that the federal highway administration need not be concerned about states using the grant money as a substitute for own-spending on highways. States appear to use highway aid to undertake projects that would not have been completed otherwise. Furthermore, this suggests that the state taxes earmarked for highways are not used as a means to free up general funds for special-interest legislation. However, the implications of this chapter can not be extended to all cases of earmarked taxes and federal grants. As Buchanan (1963) suggests, studies of crowding-out must be done on a case-by-case basis, thus providing ample opportunities for further research in this area. 


\section{References:}

Alchian, Armen A. and William R. Allen. University Economics: Elements of Inquiry. Belmont, California: Wadsworth, 1964.

Anselin, Luc. In Spatial Econometrics: Methods and Models. Dordrecht: Kluwer Academic Publishers, 1988.

Anselin, Luc and Anil Bera. "Spatial Dependence in Linear Regression Models with an Introduction to Spatial Econometrics." In Ullah, A. and D. E. Giles, editors, Handbook of Applied Economic Statistics, pages 237-289. New York: Marcel Dekker, 1998.

Anselin, Luc and S. Hudak. "Spatial Econometrics in Practice: A Review of Software Options.” Regional Science and Urban Economics 22 (1992): 509-536.

Archibald, Robert and Robert Gillingham. "An Analysis of the Short-Run Consumer Demand for Gasoline Using Household Survey Data." The Review of Economics and Statistics 62, No. 4 (Nov. 1980): 622-28.

Bailey, Stephen and Stephen Connolly. "The Flypaper Effect: Identifying Areas for Further Research." Public Choice 95, No. 3-4 (June 1998): 335-361.

Baltagi, B.H. Econometric Analysis of Panel Data. $2^{\text {nd }}$ Ed. Chichester, UK: Wiley, 2001.

Barzel, Yoram. "An Alternative Approach to the Analysis of Taxation." Journal of Political Economy 84 (Dec. 1976): 1177-97.

Barzel, Yoram and Christopher D. Hall. The Political Economy of the Oil Import Quota. Stanford, California: Hoover Institutional Press, 1977: 65-71.

Beard, T. Randolph, Paula Grant, and Richard Saba. "Border-Crossing Sales, Tax Avoidance, and State Tax Policies: An Application to Alcohol." Southern Economic Journal 64, No. 1 (July 1997): 293-306.

Becker, Elizabeth. "The Illusion of Fiscal Illusion: Unsticking the Flypaper Effect." Public Choice 86, No. 1-2 (January 1996): 85-102.

Bertonazzi, E., M.T. Maloney, and R.E. McCormick. "Some Evidence on the Alchian and Allen Theorem: The Third Law of Demand?" Economic Inquiry 31, No. 3 (1993): 383-93.

Borcherding, T.E., and E. Silberberg. "Shipping the Good Apples Out: The Alchian and Allen Theorem Reconsidered." Journal of Political Economy 86, No. 1 (1978): 131-38. 
Bowman, John. "Tax Exportability, Intergovernmental Aid, and School Finance Reform.” National Tax Journal 27 (June 1974): 163-173.

Bowman, John and John Mikesell. "Recent Changes in State Gasoline Taxation: An Analysis of Structure and Rates." National Tax Journal 36, No. 2 (June 1983): 163-182.

Bradford, David and Wallace Oates. "Towards a Predictive Theory of Intergovernmental Grants." American Economic Review 61, No. 2 (May 1971): 440-448.

Brennan, Geoffrey and James Buchanan. The Power to Tax: Analytical Foundations of a Fiscal Constitution. Cambridge: Cambridge University Press, 1980.

Brown, Robert and Todd Jewell. "County-Level Alcohol Availability and Cirrhosis Mortality.” Eastern Economic Journal 22 (1996): 291-301.

Buchanan, James. "The Economics of Earmarked Taxes." Journal of Political Economy 71 (October 1963): 457-467.

Buchanan, James. "Taxation in Fiscal Exchange.” Journal of Public Economics 6 (JulyAugust 1976): 17-29.

Buchanan, James and Geoffrey Brennan. "Tax Instruments as Constraints on the Disposition of Public Revenues.” Journal of Public Economics 9 (1978): 301-318.

Buchanan, James and Gordon Tullock. The Calculaus of Consent. Ann Arbor: University of Michigan Press, 1962.

Burkey, Mark. "A Spatial Econometric Analysis of Access to Alcohol.” Working Paper.

Case, Anne C. "Spatial Patterns in Household Demand." Econometrica 59, No 4 (July 1991): 953-965.

Case, Anne, James Hines, and Harvey Rosen. "Budget Spillovers and Fiscal Policy Interdependence: Evidence from the States." Journal of Public Economics 52 (1993): 285-307.

Clements, Kenneth and Lester Johnson. "The Demand for Beer, Wine, and Spirits: A Systemwide Analysis.” Journal of Business (July 1983): 273-304.

Cliff, A. and J. Ord. In Spatial Processes, Models, and Applications. Pion, London. 1981.

Coats, R. Morris. "A Note on Estimating Cross-Border Effects of Cigarette Taxes." National Tax Journal (1995): 573-84. 
Cook, Philip and George Tauchen. "The Effect of Liquor Taxes on Heavy Drinking." Bell Journal of Economics (Autumn 1982): 379-390.

Cook, Philip, Jan Ostermann, Frank A. Sloan. "Are Alcohol Excise Taxes Good For Us? Short and Long-Term Effects on Mortality Rates" NBER Working Paper 11138: $<$ http://www.nber.org/papers/w11138> (February 2005).

Cowen, Tyler and Alexander Tabarrok. "Good Grapes and Bad Lobsters: Applying the Alchian and Allen Theorem." Economic Inquiry 33 (Apr. 1995): 253-56.

Deran, Elizabeth. "Earmarking and Expenditures, A Survey and a New Test." National Tax Journal (December 1968).

Diamond, P. “A Many-Person Ramsey Tax Rule." Journal of Public Economics 4 (1975): 335-342.

Dubin, Robin A. "Estimation of Regression Coefficients in the Presence of Spatially Autocorrelated Error Terms." The Review of Economics and Statistics 70 (1988): 466-474.

Dye, Richard and Therese McGuire. "The Effect of Earmarked Revenues on the Level and Composition of Expenditures." Public Finance Quarterly 20, No. 4 (1992): 543-556.

Ekelund, Robert and Robert Tollison. "The Interest-group Theory of Government." Chapter 17 in William Shughart II. And Laura Razzolini, eds., The Elgar Companion to Public Choice. Cheltenham, UK: Edward Elgar, 2001: 357-378.

Eklund, Per. "A Theory of Earmarking Appraised." National Tax Journal (1972): 223227.

Elhorst, J. Paul. "Specification and Estimation of Spatial Panel Data Models." International Regional Science Review 26, No. 3 (July 2003): 244-268.

Energy Information Administration. Petroleum Marketing Annual, various years.

Feldstein, Martin. "Wealth Neutrality and Local Choice in Public Education." American Economic Review 65 (March 1975): 75-89.

Gamkhar, Shama. "Is the Response of State and Local Highway Spending Symmetric to Increases and Decreases in Federal Highway Grants?" Public Finance Review 28, No. 1 (January 2000): 3-25.

Gamkhar, Shama. "The Role of Federal Budget and Trust Fund Institutions in Measuring the Effect of Federal Highway Grants on State and Local Government Highway Expenditure." Public Budgeting and Finance 23, No. 1 (Spring 2003): 1-21. 
Gamkhar, Shama and Wallace Oates. "Asymmetries in the Response to Increases and Decreases in Intergovernmental Grants: Some Empirical Findings." National Tax Journal 49, No. 4 (December 1996): 501-512.

Garrett, Thomas and Thomas Marsh. "The Revenue Impacts of Cross-Border Lottery Shopping in the Presence of Spatial Autocorrelation." Regional Science and Urban Economics 32 (2002): 501-19.

Goetz, Charles. "Earmarked Taxes and Majority Rule Budgetary Processes." American Economic Review 58, No. 1 (March 1968): 128-136.

Gorman, D.M., Erich Labouvie, Paul Speer, and Apana Subaiya. "Alcohol Availability and Domestic Violence." American Journal of Drug and Alcohol Abuse 24 (1998): 661-673.

Gramlich, Edward. "Intergovernmental Grants: A Review of the Empirical Literature." In The Political Economy of Fiscal Federalism, ed. Wallace Oates. Lexington, MA: Heath Lexington, 1977: 219-239.

Gramlich, Edward and Harvey Galper. "State and Local Fiscal Behavior and Federal Grant Policy." Brookings Papers on Economic Activity 1 (1973): 15-58.

Grossman, Philip. "The Impact of Federal and State Grants on Local Government Spending: A Test of the Fiscal Illusion Hypothesis.” Public Finance Quarterly 18 (1990).

Gruenewald, Paul, Alex Millar, Andrew Treno, William Ponicki, Zhengmao Yang, and Peter Roeper. "The Geography of Availability and Driving after Drinking." Addiction 91 (1996): 967-983.

Gyimah-Brempong, Kwabena. "Alcohol Availability and Crime: Evidence from Census Tract Data." Southern Economic Journal 68 (2001): 2-21.

Hines, James and Richard Thaler. "Anomalies: The Flypaper Effect." Journal of Economic Perspectives 9, No. 4 (Fall 1995): 217-226.

Hogarty, Thomas and Kenneth Elzinga. "The Demand for Beer." The Review of Economics and Statistics (1972): 195-198.

Holcombe, Randall. "Public Choice and Public Finance." Chapter 19 in William Shughart II. And Laura Razzolini, eds., The Elgar Companion to Public Choice. Cheltenham, UK: Edward Elgar, 2001: 396-421.

Hsiung, Bingyuang. "A Note on Earmarked Taxes." Public Finance Review 29, No. 3 (May 2001): 223-232. 
Inman, Robert. "Towards an Econometric Model of Local Budgeting." In Proceedings of the $64^{\text {th }}$ Annual Conference on Taxation. Lexington, KY: National Tax Association, 1971: 699-719.

Johnson, Terry R. "Additional Evidence of the Effects of Alternative Taxes on Cigarette Prices." Journal of Political Economy 86, No. 2, Pt. 1 (April 1978): 325-328.

Kanbur, R. and M. Keen. "Jeux Sans Frontieres: Tax Competition and Tax Coordination when Countries Differ in Size." American Economic Review 83 (1993): 877-892.

Kayser, Hilke A. "Gasoline Demand and Car Choice: Estimating Gasoline Demand Using Household Information.” Energy Economics 22, No. 3. (Jun. 2000): 331-48.

Kelleher, K.J., S.K. Pope, R.S. Kirby, and V.I. Rickert. "Alcohol Availability and Motor Vehicle Fatalities.” Journal of Adolescent Health 19 (1996): 325-330.

Knight, Brian. "Endogenous Federal Grants and Crowd-Out of State Government Spending: Theory and Evidence from the Federal Highway Aid Program." American Economic Review 92, No. 1 (March 2002): 71-92.

Knight, Brian. "The Flypaper Effect Unstuck: Evidence on Endogenous Grants from the Federal Highway Aid Program.” Federal Reserve Board. September, 2000.

Lacombe, Donald J. "Does Econometric Methodology Matter? An Analysis of Public Policy Using Spatial Econometric Techniques." Geographical Analysis 36, No. 2 (April 2004): 105-118.

Lee, Dwight. "Overcoming Taxpayer Resistance by Taxing Choice and Earmarking Revenues." In Taxing Choice: The Predatory Politics of Fiscal Discrimination, ed. William F. Shughart II. New Brunswick: Transaction Publishers, 1997.

Leffler, KB. “Ambiguous Changes in Product Quality.” American Economic Review 72, No. 5 (1982): 956-67.

Lester, David. "Alcohol Availability, Alcoholism, and Suicide and Homicide." American Journal of Drug and Alcohol Abuse 21 (1995): 147-150.

Lucas, Vander. "Cross-border Shopping in a Federal Economy." Regional Science and Urban Economics 34 (2004): 365-385.

Manning, Willard, Linda Blumberg, and Lawrence Mouton. "The Demand for Alcohol: The Differential Response to Price.” Journal of Health Economics 14 (1995): 123148. 
Markowitz, Sara. "The Price of Alcohol, Wife Abuse and Husband Abuse." Southern Economic Journal 67 (2000): 279-303.

McMahon, W and C. Sprenkle. "A Theory of Earmaking." National Tax Journal 23 (1970): 255-262.

Meyers, Harry. "Displacement Effects of Federal Highway Grants." National Tax Journal 40, No. 2 (June 1987): 221-235.

Mikesell, John. "Sales Taxation and the Border County Problem." Quarterly Review of Economics and Business 11, No. 1 (Spring 1971): 23-29.

Mikesell, John and C. Kurt Zorn. "Impact of the Sales Tax Rate on its Base: Evidence from a Small Town.” Public Finance Quarterly 14, No. 3 (July 1986): 329-338.

Nielson, S.B. "A Simple Model of Commodity Taxation and Cross-Border Shopping." Scandinavian Journal of Economics 103, No. 4 (2001): 599-624.

Nelson, Michael. "Using Excise Taxes To Finance State Government: Do Neighboring State Taxation Policy and Cross-Border Markets Matter?" Journal of Regional Science 42, No. 4 (November 2002): 731-752.

Niskanen, William. The Demand for Alcoholic Beverages: An Experiment in Econometric Method. Santa Monica, CA: Rand Corporation. 1962.

Oates, Wallace. "Federalism and Public Finance." in Modern Public Finance, ed. J. Quigley and E. Smolensky. Harvard University Press, 1994.

Office of Highway Policy Information. Highway Statistics, various years.

Ohsawa, Yoshiaki. "Cross-border Shopping and Commodity Tax Competition Among Governments." Regional Science and Urban Economics 29 (1999): 33-51.

Olmsted, George, Arthur Denzau, and Judith Roberts. "We Voted for This? Institutions and Educational Spending." Journal of Public Economics 52 (October 1993): 345362.

Razzolini, Laura, William F. Shughart II, and Robert Tollison. "On the Third Law of Demand.” Economic Inquiry 41, No. 2 (April 2003): 292-298.

Rouwendal, Jan and Frans de Vries. " The Taxation of Drivers and the Choice of Car Fuel Type.” Energy Economics 21, No. 1 (Feb. 1999): 17-35.

Saba, R., T.R. Beard, R. Ekelund Jr., and R. Ressler. "The Demand for Cigarette Smuggling.” Economic Inquiry 33 (1995): 189-202. 
Saffer, Henry and Michael Grossman. "Beer Taxes, the Legal Drinking Age, and Youth Motor Vehicle Fatalities." The Journal of Legal Studies (June 1987): 351-374.

Sandmo, A. "Optimal Taxation in the Presence of Externalities." Swedish Journal of Economics (1975): 86-98.

Scribner, Richard, Deborah Cohen, and T.A. Farley. "A Geographic Relation Between Alcohol Availability and Gonorrhea Rates." Sexually Transmitted Diseases 25 (1999): 544-548.

Scribner, Richard, Deborah Cohen, Stephen Kaplan, and Susan Allen. "Alcohol Availability and Homicide in New Orleans: Conceptual Considerations for Small Area Analysis of the Effect of Alcohol Outlet Density." Journal of Studies on Alcohol 60 (1999): 310-316.

Shughart, Willima F., ed. Taxing Choice: The Predatroy Politics of Fiscal Discrimination. New Brunswick: Transaction Publishers, 1997.

Slemrod, Joel. "Optimal Taxation and Optimal Tax Systems." Journal of Economic Perspectives 4, No. 1 (Winter 1990): 157-178.

Sobel, Russell S. and Thomas A. Garrett. "Taxation and Product Quality: New Evidence from Generic Cigarettes." Journal of Political Economy 105, No. 4 (1997): 880-87.

Sumner, Michael T. and Robert Ward. "Tax Changes and Cigarette Prices." Journal of Political Economy 89 (December 1981): 1261-1265.

Tatlow, James, John Clapp, and Melinda Hohman. "The Relationship Between the Geographic Density of Alcohol Outlets and Alcohol Related Hospital Admissions in San Diego County." Journal of Community Health 25 (2000): 79-88.

Thursby, Marie, Richard Jensen, and Jerry Thursby. "Smuggling, Camouflaging, and Market Structure.” Quarterly Journal of Economics (August 1991): 789-814.

Thursby, Jerry and Marie Thursby. "Interstate Cigarette Bootlegging: Extent, Revenue Losses, and Effects of Federal Intervention." National Tax Journal 53, No. 1 (March 2000): 59-77.

Tiebout, Charles. "A Pure Theory of Local Government Expenditures." Journal of Political Economy 64, No. 5 (October 1956): 416-424.

Trandel, G.A. "Interstate Commodity Tax Differentials and the Distribution of Residents." Journal of Public Economics 53 (1994): 435-457.

Umbeck, J.R. "Shipping the Good Apples Out: Some Ambiguities in the Interpretation of 'Fixed Charge.'” Journal of Political Economy 88, No. 1 (1980): 199-208. 
Wales, Terence. "Distilled Spirits and Interstate Consumption Effects." American Economic Review (September 1968): 853-863).

Wang, Y.Q. "Commodity Taxes Under Fiscal Competition: Stackelberg Equilibrium and Optimality." American Economic Review 89, No. 4 (1999): 974-981.

Weicher, John. “Aid, Expenditures, and Local Government Structure." National Tax Journal 25 (December 1972): 573-583.

Weingast, Barry R., Kenneth A. Shepsle, and Christopher Johnsen. "The Political Economy of Benefits and Costs: A Neoclassical Approach to Distributive Politics." Journal of Political Economy 89, No. 4 (1981): 642-664

Xie, X., R.E. Mann, and R.G. Smart. "The Direct and Indirect Relationships Between Alcohol Prevention Measures and Alcoholic Liver Cirrhosis Mortality." Jounal of Studies on Alcohol 61 (2000): 499-506.

Yellvington, Brenda. "Excise Taxes in Historical Perspective." In Taxing Choice: The Predatory Politics of Fiscal Discrimination, ed. William F. Shughart II. New Brunswick: Transaction Publishers, 1997.

Young, Douglas and Agnieszka Bielinska-Kwapisz. "Alcohol Prices and Beverage Taxes.” National Tax Journal 55 (March 2002): 57-73. 